Maurice A. Deane School of Law at Hofstra University Scholarly Commons at Hofstra Law

Hofstra Law Faculty Scholarship

1993

\title{
Toward "Neutral Principles" in the Law: Selections from the Oral History of Herbert Wechsler
}

Norman I. Silber

Maurice A. Deane School of Law at Hofstra University

Geoffrey Miller

Follow this and additional works at: https://scholarlycommons.law.hofstra.edu/faculty_scholarship

\section{Recommended Citation}

Norman I. Silber and Geoffrey Miller, Toward "Neutral Principles" in the Law: Selections from the Oral History of Herbert Wechsler, 93 Colum. L. Rev. 854 (1993)

Available at: https://scholarlycommons.law.hofstra.edu/faculty_scholarship/535

This Article is brought to you for free and open access by Scholarly Commons at Hofstra Law. It has been accepted for inclusion in Hofstra Law Faculty Scholarship by an authorized administrator of Scholarly Commons at Hofstra Law. For more information, please contact lawcls@hofstra.edu. 


\title{
TOWARD "NEUTRAL PRINCIPLES” IN THE LAW: SELECTIONS FROM THE ORAL HISTORY OF HERBERT WECHSLER
}

\author{
Norman Silber* and Geoffrey Miller**
}

\begin{abstract}
Herbert Wechsler entered the City College of New York when he was fifteen years old; he was twenty-two when he finished at the top of the Columbia Law School class of 1931. He taught at Columbia Law School for a year, clerked with Justice Harlan Fiske Stone, and returned to teaching instead of to private practice-having decided, he stated later, that he would rather "try and think great thoughts than do great things." His subsequent career, much of it spent at Columbia, reflects attention to both understanding and fostering the coherence of the legal system. He took a pivotal role in conceptualizing the Model Penal Code. He authored two exceptional casebooks: with Henry Hart, Hart and Wechsler's The Federal Courts and the Federal System, ${ }^{2}$ and with Jerome Michael, Criminal Law and Its Administration. ${ }^{3}$ For more than twenty years, he directed the activities of the American Law Institute, including the publication of its Restatements. ${ }^{4}$ In addition to
\end{abstract}

* Associate Professor, Hofstra University Law School; Ph.D., Yale University, 1978; J.D., Columbia University, 1986.

** Kirkland \& Ellis Professor, University of Chicago Law School; J.D., Columbia University, 1978.

The authors wish to thank Alex Aleinikoff, Eugene Aleinikoff, Albert Alschuler, Richard Bernstein, David Cohen, Monroe Freedman, Dennis Hutchinson, Bernard Jacob, William Nelson, Mark Tushnet, and participants at the New York University Legal History Colloquim for extraordinarily helpful comments; Yotvat "Adi" Altschuler, Aaron "Chris" Bryant, and David Gold for valuable research assistance; the Lynde and Harry Bradley and Sarah Scaife Foundations for supporting Professor Miller's research, Hofstra University for supporting Professor Silber's research; and Dr. Ron Grele and the Oral History Research Office of Columbia University for encouragement and support throughout. Our debt to Herbert Wechsler, whose kindness, generosity, and cooperation were unflagging, should be evident on every page of this work.

1. Columbia University Oral History Project, Life of Herbert Wechsler 96 (Norman Silber \& Geoffrey Miller interviewers, 1982) [hereinafter Oral History].

2. Henry M. Hart, Jr. \& Herbert Wechsler, The Federal Courts and the Federal System (1953). Now entitled Hart \& Wechsler's The Federal Courts and the Federal System (3d ed. 1988), by Paul M. Bator et al., the book remains a staple of the federal courts course at many law schools.

3. Jerome Michael \& Herbert Wechsler, Criminal Law and Its Administration: Cases, Statutes and Commentaries (1940). Although the book was recognized as a classic at the time of its publication, no new edition has appeared.

4. Among the leading restatements published under Wechsler's directorship are the Restatement (Second) of Agency (1958); Restatement (Second) of Conflict of Laws (1971); Restatement (Second) of Contracts (1981); Restatement (Second) of the Foreign Relations Law of the United States (1965); Restatement (Second) of Judgments (1982); Restatement (Second) of Torts (I965); and the Restatement (Second) of Trusts (1959). Other important publications of the American Law Institute published under Wechsler's directorship are the Model Land Development Code (1976); Model Penal Code (Proposed Official Draft 1962); the Model Code of Pre-arraignment Procedure 
his other writings, at least two articles, The Political Safeguards of Federalism, ${ }^{5}$ and Toward Neutral Principles of Constitutional Law, ${ }^{6}$ have had a continuing influence on the meaning of constitutionalism and the nature of judicial decisionmaking. ${ }^{7}$

Professor Wechsler also participated in private civil liberties litigation during his career, and at other times occupied posts of considerable infuence as a government attorney. As a young law teacher in the early 1930s, he played a major part in shaping the argument, including most of the Supreme Court briefs, for Angelo Herndon, a black communist sentenced to prison for pure speech. ${ }^{8}$ As an official in the United States Department of Justice in 1941, Wechsler argued and won the important case of United States v. Classic, ${ }^{9}$ which broadened the availability of civil rights remedies by applying the federal Civil Rights Act to fraud in primary elections for the United States Congress. ${ }^{10}$ As Assistant

(Proposed Official Draft 1975); and the Study of the Division of Jurisdiction Between State and Federal Courts (1969).

5. Herbert Wechsler, The Political Safeguards of Federalism: The Role of the States in the Composition and Selection of the National Government, 54 Colum. L. Rev. 543 (1954).

6. Herbert Wechsler, Toward Neutral Principles of Constitutional Law, 73 Harv. L. Rev. 1 (1959) [hereinafter Neutral Principles]. One indication of this article's influence is the extent to which it continues to provoke controversy and attract citations. See, e.g., Morton J. Horwitz, The Transformation of American Law 1870-1960, at 265-68 (1992); Richard Posner, The Material Basis of Jurisprudence (preliminary draft January 19, 1993, on file with the Columbia Law Review); Eugene V. Rostow, The Sovereigu Prerogative: The Supreme Court and the Quest for Law 24-39 (1962); Kent Greenawalt, The Enduring Significance of Neutral Principles, 78 Colum. L. Rev. 982 (1978); Earl M. Maltz, Some Thoughts on the Death of Stare Decisis in Constitutional Law, 1980 Wis. L. Rev. 467, 483; Gary Peller, Neutral Principles in the 1950s, 21 U. Mich. J.L. Ref. 561 (1988); Edward L. Rubin, On Beyond Truth: A Theory for Evaluating Legal Scholarship, 80 Cal. L. Rev. 889, 917-18 (1992); Cass R. Sunstein, Lochner's Legacy, 87 Colum. L. Rev. 873, 894-95 (1987); Cass R. Sunstein, Neutrality in Constitutional Law (with Special Reference to Pornography, Abortion, and Surrogacy), 92 Colum. L. Rev. 1, 5 (1992) (Wechsler's Neutral Principles article is "the most celebrated essay in all of constitutional law"). For an empirical perspective on the article's influence, see Fred R. Shapiro, The Most-Cited Law Review Articles, 73 Cal. L. Rev. 1540, 1549 (1985) (Neutral Principles found to be the second most heavily cited law review article).

7. Judge Richard Posner, for example, recently stated:

[T] here is no longer anyone in the legal profession who has the kind of stature that Wechsler achieved, with his service at Nuremberg, his Supreme Court advocacy, his coauthorship of the most famous casebook in legal history .... , his authorship of the Model Penal Code, and his directorship of the American Law Institute when that institution had an eminence it no longer has.

Posner, supra note 6 , at 41.

8. See Herudon v. Lowry, 301 U.S. 242 (1937), discussed infra notes 53-57 and accompanying text. Wechsler's participation in Herndon's defense is discussed in Charles H. Martin, The Angelo Herndon Case and Southern Justice 140-42 (1976); Kendall Thomas, Rouge et Noir Reread: A Popular Constitutional History of the Angelo Herndon Case, 65 S. Cal. L. Rev. 2599, 2700 \& n.397 (1992).

9. 313 U.S. 299 (1941).

10. See generally David M. Bixby, The Roosevelt Court, Democratic Ideology, and Minority Rights: Another Look at United States v. Classic, 90 Yale L.J. 741, 745 (1981) 
Attorney General in charge of the War Division during World War II, Wechsler supervised all litigation related to the relocation and internment of individuals of Japanese ancestry. And at the close of the War, he first helped to define the nature of the Allied war crimes prosecution and later served as a key aide and advisor to the judicial tribunal at Nuremberg. Wechsler continued to be active as an attorney after the war. In New York Times Co. v. Sullivan, ${ }^{11}$ Wechsler's advocacy resulted in a Supreme Court decision refashioning the contours of the law of libel.

The dialogue that follows, concerned largely with the development and maturation of Professor Wechsler's legal and philosophical outlook, is a selection from among many subjects discussed in a series of interviews, sponsored by the Columbia Oral History Research Project, which we conducted jointly between 1978 and 1982. We edited and annotated the present work; the annotations reflect our views and not necessarily those of Professor Wechsler. Our questions and notations are shown in italic type and Professor Wechsler's remarks are printed in roman.

\section{The Closed System}

Wechsler: I was not only apolitical, but rather anti-political in college. My interest was in the arts, not in politics. I took the usual view of politicians, holding them in low esteem. I thought the least government the best. I didn't want to be interfered with in my choices. This was symbolized for my generation by things like the Prohibition Amendment, which we defied with total abandon. It never entered my mind that there might be any obligation to obey the temperance law. I considered it entirely a matter of trying to avoid wood alcohol poisoning.

Not until law school did I begin to take seriously at all the subject of government. And even though I became greatly interested in law and government during my law school days, and therefore, by necessity, in politics, I was not very much of a political partisan. I was interested in the problems and ideas about government, but I never participated in organized politics of any kind, at that stage, and I rather tended to view with disdain people who did.

I entered Columbia Law School in 1928 at a moment of great tension at that school. It was the year after the schism in the faculty that had really broken it in two and led to the departure of some of the best known members-Moore, Oliphant, Cook. ${ }^{12}$ The schism really had to

(examining Classic in terms of the emergence of a new ideology relating to minority rights).

11. New York Times Co. v. Sullivan, 376 U.S. 254 (1964). For a detailed account of Wechsler's involvement in the brief writing and oral argument of this case, see Anthony Lewis, Make No Law: The Sullivan Case and the First Amendment 103-22, 127-39 (1991).

12. William Underhill Moore (1879-1949): Moore had been Professor of Law at 
do with what law schools should be concerned with.

Let's take the mid-twenties as a good starting point-the Taft Court, ${ }^{13}$ the Holmes-Brandeis dissents in the Supreme Court. The conservative view, which was dominant in the profession and in the courts, essentially had these characteristics: it was anti-legislative; it was anti-administrative; it glorified the common law as administered by courts. What's more, the conservative position viewed the common law

Columbia Law School, specializing in commercial bank credit and business organizations. After Young Smith was appointed Dean of the Law School in 1928, Moore did not resign like Oliphant and Cook, but remained at Columbia despite bad relations with other faculty members. He resigned in 1930, accepting a position with the Yale Institute of Human Relations. Advocating "scientific objectivity," Moore employed empirical studies in his research, the most famous of which concerned traffic control and parking behavior in New Haven. He claimed that his studies had practical application in law because they helped predict judicial decisions. He retired from the Yale Law School faculty in 1947. See Foundation for Research in Legal History Under the Direction of Julius Goebel, Jr., A History of the School of Law, in the Bicentennial of Columbia University 249-52 (1955) [hereinafter Goebel]; John Henry Schlegel, American Legal Realism and Empirical Social Science: The Singular Case of Underhill Moore, 29 Buff. L. Rev. 195 (1980).

Herman Oliphant (1873-1943): Upon his graduation from the University of Chicago Law School in 1914, Oliphant became an instructor there, advancing to full professor in 1919. In 1921 he moved to Columbia, where he remained a professor of contract law until he resigned after he was passed over as a candidate for the deanship in 1928. He then joined Walter Wheeler Cook, Hessel Yntema, and Leon Marshall in founding the research-oriented Institute of Law at Johns Hopkins University. Throughout his career, Oliphant specialized in commercial subjects, teaching trade regulation at Columbia University School of Law and business organizations in the School of Business. His research and writing called for a scientific study of how law operates in a social context, and thus he was known as one of the Columbia empiricists or scientific realists. In 1933 he became a prominent legal advisor in the Roosevelt Administration. See Goebel, supra, at 265-67, 304-05.

Walter Wheeler Cook (1873-1943): Cook studied law at Columbia, earning the A.M. degree in 1899 and the LL.M. degree in 1901 . He went immediately into law teaching, became a full professor at the University of Nebraska in 1903, and thereafter taught at the University of Missouri (1904-1906), University of Wisconsin (1906-1910), University of Chicago (1910-1916), Yale (1916-1919 and 1922-1928), Columbia (1919-1922), and Northwestern (1935-1943). While visiting Johns Hopkins from Yale in 1926-1928, he contributed to the founding of the new Institute of Law; he joined Hessel Yntema, Leon Marshall, and Herman Oliphant in 1928 and stayed until the Institute's funding ran out in 1933. Throughout his career, Cook contributed to the Legal Realist movement by emphasizing the role that modern scientific method should play in gathering facts about and evaluating legal doctrines in relation to social goals. See Goebel, supra, at 262-64; Charles E. Clark et al., Walter Wheeler Cook, 38 Ill. L. Rev. 341 (1944); see also Laura Kalman, Legal Realism at Yale, 1927-1960, at 112-13, 124 n.85 (1986).

13. William Howard Taft (1857-1930): Taft served as president of the United States (1908-1912). After losing his bid for re-election, he taught constitutional law at Yale Law School and served as President of the American Bar Association. He was a leading opponent of Louis Brandeis' nomination to the Supreme Court in 1916. Appointed to the Supreme Court in 1921 by President Harding, Taft served as Chief Justice between 1921 and 1930. See Geoffrey Stone et al., Constitutional Law at lxxii (2d ed. 1991). 
as Langdell ${ }^{14}$ had viewed it-basically as a closed system.

In other words, here's a body of law that has an answer to all legal issues that may rise in a controversy between man and man, or man and state. These issues are to be determined by logical application to new circumstances of the rules and principles enunciated by the courts, over time, in judicial decisions. The view was that the whole process of learning, understanding and applying law was a process of uncovering the leading cases, the precedents, relevant to a particular situation, and by strict logical deduction, applying tbem consistently to new situations.

There was no room for legislative or quasi-legislative judgment in this process. It was not a matter of choice of values. The system was there, its roots in what common law courts had developed in England. It had been received in the strict sense-imported into the United States, first by colonization and then, after the Revolution, by constitutionally mandated reception, and that's what you were to work with. That was law.

I don't believe that you fellows could have the slightest conception of what it was like to talk to a lawyer who believed that way, about the way the devout affirm their religious convictions.

That conception of common law as a closed system was the thing that, for example, Cardozo's The Nature of the Judicial Process and The Growth of the Law and The Paradoxes of Legal Science, three series of lectures, were really written to combat. ${ }^{15}$ The roots of that combat, I sup-

14. Christopher Columbus Langdell (1826-1906): As a Professor and Dean at the Harvard Law School, Langdell encouraged such innovations as the use of examinations and the case method. The latter development was grounded in Langdell's belief that law should be studied as a science, reduced to a few immutable principles or doctrines. Langdell wrote that "each of these doctrines has arrived at its present state by slow degrees; in other words it is a growth, extending in many cases through centuries. This growth is to be traced in the main through a series of cases; and much the shortest and the best, if not the only way of mastering the doctrine effectually is by studying the cases in which it is embodied." Christopher C. Langdell, A Selection of Cases on the Law of Contracts: With References and Citations at vi-vii (1871). Although his innovations were met initially with skepticism, Langdell's "revolution" eventually won a following in virtually all American law schools and served as the industry standard in American legal education. See Lawrence M. Friedman, A History of American Law 615-17 (2d ed. 1985). Langdell's influence reached Columbia by 1891, when University President Seth Low and Law School Professor William Albert Keener introduced the case method there. See Goebel, supra note 12, at 152-55.

lronically, while Langdell pioneered innovations in the method of legal education, his confidence that areas of the law could be reduced to a few, timeless principles later identified him in the eyes of Legal Realists as a backward-looking conservative. See William Twining, Karl Llewellyn and the Realist Movement 10-25 (1985). On the relationship between the case method and realism, see also Karl N. Llewellyn, Jurisprudence: Realism in Theory and Practice 376-79, 383-89 (1962).

15. Benjamin N. Cardozo, The Nature of the Judicial Process (1921); Benjamin N. Cardozo, The Growth of the Law (1924); Benjamin N. Cardozo, The Paradoxes of Legal Science (1928). 
pose, go back to the Holmes Lowell Lectures, that became The Common Law. ${ }^{16}$

The struggle between the Langdellian closed system adherents and the opponents of that view was really the central intellectual issue in American law in the forepart of the century. 1t was involved in Wilsonianism, ${ }^{17}$ in Teddy Roosevelt and the Bull Moose business, ${ }^{18}$ and in the public pronouncements of people like Elihu Root ${ }^{19}$ on the administrative law-really the father of American administrative lawhe fought in support of it. Charles Evans Hughes took on the closed system during his governorship. ${ }^{20}$ This was also part of Wisconsin

16. Oliver W. Holmes, Jr., The Common Law (1881). For the views of a distinguished federal judge and legal scholar on these historic figures, see Richard A. Posner, Cardozo: A Study in Reputation (1990); The Essential Holmes: Selections from the Letters, Speeches, Judicial Opinions and Other Writings of Oliver Wendell Holmes, Jr. (Richard A. Posner ed., 1992).

A recent discussion of the attack against formalism in American legal scholarship during this period can be found in Horwitz, supra note 6, at 188-92.

17. Wilsonianism: The political views associated with Woodrow Wilson, a distinguished political scientist and President of Princeton University, Governor of New Jersey, and twenty-eighth President of the United States, reflecting "a maturing conviction that scientific knowledge of economic, political, and administrative practices could be introduced into the conduct of government." Niels A. Thorsen, The Political Thought of Woodrow Wilson, 1875-1910, at x-xi (1988). See also Henry S. Commager, The American Mind: An lnterpretation of American Thought and Character Since the 1880's, at 349-50 (1950).

18. Bull Moose: A member of the third party led by Roosevelt in the presidential election of 1912 after Roosevelt's split with the Republican Party at the convention. All three candidates in the 1912 campaigu-Taft, Wilson, and Roosevelt_-"reasoned from the same premises: . . . they assumed the responsibility of the national government for guidance, and they conceived of that guidance in bureaucratic terms. All major parties, in other words, claimed the privilege of completing the national progressive movement." Robert H. Wiebe, The Search for Order, 1877-1920, at 217 (1967).

19. Elihu Root (1845-1937): The valedictorian of Hamilton College's class of 1864, Root graduated from New York University Law School in 1867 and went immediately into private practice. In 1899 Root became Secretary of War under McKinley, and in 1905 Secretary of State under Roosevelt. In 1909 he was elected to the United States Senate. He joined with other orthodox legal thinkers to establish the American Law Institute in 1923. See Philip C. Jessup, Elihu Root (Archon Books 1964) (1938); Richard W. Leopold, Elihu Root and the Conservative Tradition (1954); Edward A. Purcell, Jr., The Crisis of Democratic Theory: Scientific Naturalism and the Problem of Value 79-80 (1973).

20. Charles Evans Hughes (1862-1948): A graduate of Brown University and Columbia University Law School, Hughes pursued a long and distinguished career as a lawyer, statesman, and jurist. In 1906, he defeated the Democrat William Randolph Hearst in a race for the New York Governor's office. A somewhat "frosty progressive," Hughes's governorship initiated far-reaching legal and administrative reforms. During his first term, Hughes convinced the legislature to create two public service commissions to regulate utilities. He resigned on October 6,1910 to accept appointment by Taft to the United States Supreme Court. Hughes served as an Associate Justice until 1916, when he resigned to run against Wilson in the election of 1916. After losing the election, he practiced law in New York. He was appointed Secretary of State in 1921. On February 3, 1930, he was nominated by Hoover to serve as Chief Justice of the 
Progressivism. ${ }^{21}$

But here in the East, particularly in New York, the closed system was still quite pervasive gospel, and it is not hyperbolic to say that on the whole, anyhody that didn't share this faith was regarded as subversive. Perhaps it was proper to regard such a person as a subversive, because really, once you abandoned that view, the law was, so to speak, up for grabs-you ceased to have an assured continuity and stability.

Because the decisions of the common law are often contradictory?

That's much of it. The big point of Cardozo's book was to show that this continuity and stability were illusory-that even if you wanted it to be a closed system, you couldn't have it, because the sources were too inconsistent. They led in opposite directions, and an element of reasoned choice was essential if the judge was to know what he was doing. The advocates of legislative participation in law insisted on the simple proposition that tempora mutanda-law had to change as the times changed and the problems changed.

How did the conflict between the closed and open views unfold at Columbia?

Harlan Fiske Stone, ${ }^{22}$ during his tenure as Dean of the Columbia Law School, was a most effective, middle-of-the-road advocate of that

United States, which he did until his retirement in 1941. See The Autobiographical Notes of Charles Evans Hughes (David J. Danelski \& Joseph S. Tulchin eds., 1973); Merlo J. Pusey, Charles Evans Hughes (1951).

21. Wisconsin Progressivism: A political reform movement that included dissatisfied Republicans who supported Wisconsin Senator Robert Marion LaFollette (1855-1925) as a candidate for President. While his bid for the presidency failed, LaFollette "did make an experimental laboratory of his own state. ... Under LaFollette's guidance, or inspiration, that state pioneered in the effective regulation of public utilities, conservation, scientific agriculture, income and inheritance taxes, workmen's compensation, social security, and a dozen other measures that were later to emerge as part of the New Freedom or the New Deal." Commager, supra note 17, at 352; accord David P. Thelen, The New Citizensbip: Origins of Progressivism in Wisconsin, $1885-1900$, at $290-308$ (1972).

22. Harlan Fiske Stone (1872-1946): Stone graduated from Amherst College in 1894 and became principal of the Putnam High School in Newburyport, Massachusetts. Graduating from the Columbia School of Law in 1898, he joined the New York bar, practicing initially as an associate with Clark, Sullivan \& Cromwell. Beginning in 1899 he devoted part of his time to Columbia Law School as a lecturer in law, initiating what would eventually become a long and distinguished teaching career. He became an adjunct Professor at Columbia in 1903. When it became known that Columbia Law School Dean George W. Kirchway was leaving his position in 1908, Stone tentatively agreed to serve as Dean upon the condition that new appointments to the faculty be made only after consulting him. Shortly thereafter a new professor was appointed without Stone's input, and Stone withdrew his commitment to serve as Dean. In 1910, after acting Dean Harry A. Cushing left Columbia, Stone finally agreed to return to Columbia as the Dean of the Law School. In addition to his decanal duties, he taught trusts, mortgages, and equity. In 1924, Stone resigued to return briefly to private practice, and then accepted an appointment as Attorney General of the United States. President Coolidge appointed him to the United States Supreme Court in 1925. In 1941 he was promoted by President Roosevelt to Chief Justice. See Goebel, supra note 12, at 215-21; Alpheus Thomas Mason, Harlan Fiske Stone: Pillar of the Law (1956). 
straightforward view. I mean he was middle-of-the-road because precedent was important to him, continuity was important, and people who would change things had to carry the burden of persuasion that change was desirable. He was interested in legislation, not hostile to legislation. He wasn't a madman about the closed system, but he was a conservative.

There also was a more extreme group at Columbia, however, that repudiated the closed system and did so in a way that was essentially sociological in its interests and approach. Cook, Oliphant, Moore and several others insisted on the need for elaborate empirical examination of the effects of legal arrangements on institutions, and their focus was less on the process of evaluation than on the need for adequate empirical data. ${ }^{23}$ They somehow would have converted legal teaching and legal scholarship to focusing predominantly on empirical information. Moore, for example, has an article in the Yale Law Journal that is based on counting-standing at a corner at a traffic light and counting the number of people who stop for a red light and who don't. ${ }^{24}$

The followers of Stone regarded the extreme view as non-viable for establishing a law school curriculum. They regarded it as excessive in its empirical demands, and perhaps, they would have said, impractical of attainment. You know, you could spend years making these studies of the effects of the rule against perpetuities, for example, and by the time you got done with the study, the situation would have changed so completely that your study would be of no use for the business of evaluation and consideration of change.

When Stone moved on to law practice and the Supreme Court, the middle-of-the-roaders at Columbia lined up behind Young Smith, who had been close to Stone throughout, as their candidate for the new Dean. ${ }^{25}$ And when Smith was chosen, the empiricists, if I can call them that, on the whole lit out.

That was the very time when the empirical view attained support

23. On the approach utilized by this group, see Horwitz, supra note 6 , at 181 . Horwitz criticizes these scholars for adopting "the narrowest and most naively behavioralist versions of positivist social science." Id.

24. See Underhill Moore \& Charles C. Callahan, Law and Learning Theory: A Study in Legal Control, 53 Yale L.J. 1 (1943). This article summarized 10 years spent observing how New Haven drivers responded to parking limitations and traffic circles. These costly traffic studies and the related articles are discussed in Schlegel, supra note 12 , at 264-93.

25. Young Berryman Smith (1889-1960): Smith graduated from the University of Georgia in 1909 and from Columbia School of Law in 1912. He practiced law in New York and Georgia. He began his teaching career as an instructor in contracts at Emory University Law School, in Atlanta, and by 1919 he was a full Professor of Law at Columbia. His candidacy for the deanship in 1928 was opposed by the members of the law school faculty who wished the law school to place greater emphasis on empirical research. After his appointment in 1928, many of the opposing faculty resigned in protest. Smith remained Dean until 1952. See Goebel, supra note 12, at 253-54, 303-05, 378. 
at Johns Hopkins in the establishment of a new institution there. ${ }^{26}$ Oliphant and Cook went to Johns Hopkins. Some went to Yale. Their places were filled by younger people, many of whom were teaching for the first time in the year 1 entered, 1928.

So you entered after the radicals had gone?

Yes. I was there in the immediate post-revolutionary period. I was in Goebel's first class. ${ }^{27}$ Berle hadn't been there very long. ${ }^{28}$ Some of the people we had were flashes in the pan-I mean visitors who weren't invited to stay, who didn't stay. Some of these people were interested in legislative development, with the legislative drafting office that had recently been set up and that was run by Joe Chamberlain and Tom Parkinson, for example. ${ }^{29}$ But at least the group that was there was

26. See supra notes 23-24 and accompanying text.

27. Julius Ludwig Goebel, Jr. (1892-1973): Goebel took undergraduate and masters degrees from the University of lllinois, and earned a Ph.D. in International Law at Columbia Law School in 1915. After practicing law in Washington D.C., principally as legal advisor to the Swiss legation, serving in the Army in 1918, and teaching as an acting adjunct professor at the University of Virginia, Goebel returned to Columbia to lecture on international law in 1921. He would later complete the requirements for an LL.B. degree from Columbia and shift his interests from international law to legal history, eventually becoming the George Welwood Murray Professor of Legal History. He emphasized the "political, economic, or social factors in the growth of particular rules or institutions and utilized the most varied of sources to establish how manifold are the factors at work in the process of origination and subsequent function." Goebel, supra note 12 , at $314-15$.

28. Adolph A. Berle, Jr. (1895-1960): A Bostonian, Berle graduated from the Harvard Law School in 1916. He practiced law and taught corporate finance at the Harvard Graduate School of Business Administration. In 1927 he became a lecturer at Columbia Law School and in 1928 joined the faculty as an Assistant Professor. A leader in curricular reform, he introduced an advanced course in 1929 "in which business associations were approached as financial devices in the light of economic and legal materials relating principally to the problems of corporate finance." Goebel, supra note 12, at 316-17. With Gardiner C. Means, Berle wrote a revolutionary study of corporate law and finance, The Modern Corporation and Private Property (1933), which remains a fundamental text in the study of corporations, even though its normative implications have been challenged by subsequent scholars, especially those associated with the Law and Economics Movement. See generally Jordan A. Schwarz, Liberal: Adolph A. Berle and the Vision of an American Era (1987). For assessments of the significance of the Berle-Means book, see generally Symposium, Corporations and Private Property, 26 J.L. \& Econ. 235, 235-496 (1983). For a contrasting view on corporate law and finance, which is nevertheless indebted to the basic Berle-Means tradition, see generally Frank H. Easterbrook \& Daniel R. Fischel, The Economic Structure of Corporate Law (1991).

29. The Legislative Drafting Office: Professor Joseph P. Chamberlain, infra, established the Legislative Drafting Research Fund at Columbia Law School in 1909. Along with Tom Parkinson and others, Chamberlain led the technical staff, which devoted its full time and energy to legislative research and drafting. In its first year, the Fund drafted a proposed federal workmen's compensation statute, a proposed amendment to the New York Constitution authorizing a state workmen's compensation statute, a bill revising laws related to sbipping and safety of passengers, and (with the Commissioners on Uniform State Laws) a Uniform Probate of Wills Act and a Uniform Workmen's Compensation Act. In 1917 Chamberlain provided financial support for a permanent fund and created an endowed professorship of legislation in the law school. 
united in its repudiation of closed system concepts.

Which professors were most influential in your development?

Julius Goebel, Karl Llewellyn, and Jerome Michael. ${ }^{30}$

How did they shape your perspective?

Well, as I said later in my Harvard speech, four articles of faith seem to me to have developed during my years as a law student, from 1928 to $1931 . .^{31}$ The first is the same one I just talked to you about-

The Fund employed students and provided them with practical experience in legislative drafting. The Fund's work inspired the creation of the United States Legislative Drafting Service in 1919. See Goebel, supra note 12, at 255-58.

Joseph Perkins Chamberlain (1873-1951): Chamberlain received an LL.B. from Hastings College of Law and practiced law in San Francisco and New York City. He helped found the Legislative Drafting and Research Fund, earned a Ph.D. from Columbia in 1923, and became Professor of Public Law in the Columbia Faculty of Political Science. He later prepared a draft of the treaty that became the Kellogg-Briand Pact. See Goebel, supra note 12, at 284-86.

Thomas Ignatius Parkinson (1881-1959): Parkinson graduated from the University of Pennsylvania Law School and joined the Pennsylvania bar in 1902. He came to New York City as counsel to the New York Bureau of Municipal Research in 1908, and was named Director of the Legislative Drafting and Research Fund upon its founding. In 1917 he became the first Professor of Legislation in the Columbia School of Law. See Goebel, supra note 12 , at $255-58$.

30. Karl Nickerson Llewellyn (1893-1962): A Phi Beta Kappa graduate of Yale College, Llewellyn also earned both the LL.B. (1918) and the J.D. (1920) from Yale Law School. He practiced briefly in New York City with Shearman \& Sterling. He then turned to teaching and scholarship, first at Yale (1922-1925), then at Columbia (1930-1951), and finally at the University of Chicago (1951-1962). Llewellyn's early work was in the field of commercial law; his first book, Cases and Materials on the Law of Sales (1930), emphasized the pragmatic aspects of the contract for delivery of goods and downplayed the more theoretical issues relating to passage of title. During his career, his wide-ranging intellectual curiosity led him to jurisprudential issues, earning him his status as a prominent and controversial legal realist. $\mathrm{He}$ also assisted the Commissioners on Uniform State Laws and was one of the chief drafters of the Uniform Commercial Code. See Goebel, supra note 12, at 280-81; see generally Twining, supra note 14.

Jerome Michael (1890-1953): Michael graduated from the University of Georgia and the Columbia School of Law. Upon finishing his legal education, he returned to Athens, where he worked briefly in private practice and served as City Attorney. After serving in the United States Army in World War 1, he practiced law in New York City. He then served under Harlan Stone in the War Transactions Section of the Department of Justice, and in 1927 he came to Columbia Law School as a full Professor. He initially taught civil procedure, but did his greatest work on the law of evidence in conjunction with Mortimer J. Adler of the University of Chicago. Michael and Adler ultimately developed a distinctive analysis of the rules of evidence in terms of symbolic logic and neo-Aristotelian philosophy. See Goebel, supra note 12, at 287-88. Professor Wechsler's high regard for Michael is reflected in Herbert Wechsler, Jerome Michael, 1890-1953, 53 Colum. L. Rev. 301 (1953).

31. See Herbert Wechsler, The Law Schools and the Law, Harv. L. Sch. Bull., July 1967, at 4, 4-7. Professor Wechsler's oral remarks summarize points made at greater length in this article, to which the reader is referred for more detail. From the vantage point of 1967, it appeared to Wechsler that these tenets had triumphed. Evaluating the fate of these four tenets, Wechsler remarked:

These articles of faith sustained me in my youth, and I make bold to say that 
the frontal challenge to the concept of the common law as a closed system.

The second point in the credo called for judicial receptivity to statutory changes of the common law and sympathetic treatment of administrative agencies entrusted with new regulatory functions.

The third point was unqualified disdain for the then-dominant interpretation of the Constitution by the Supreme Court of the United States, precluding any governmental action in the ordering of the economy, despite the magnitude of the abuse, and the dislocation incident to the development of an industrial society.

The fourth article of faith, perhaps the most important in my present perspective, was the one affirming that legal understanding is imperfectly attained, so long as law is treated as an independent discipline consisting soley of an ordering of rules and doctrines drawn from statutes and decisions.

Did you try while you were Editor-in-Chief of the Columbia Law Review to make it a mouthpiece for opposition to the closed system?

I accepted that view at the very beginning, and I'm sure it entered into anything that I wrote or thought or believed. But I don't think that I was animated by specific intent to make the Review a vehicle for anything, other than doing good work. I think I was very much a jobbist. I still am. Concerned with competence and integrity, intellectual integrity, in thinking about law and working in law.

How did you get a clerkship with Justice Stone?

That came out of the blue, really. I had been interviewed by the Justice for a clerkship in the I93 I-1932 term, but lost to my classmate Walter Gellhoru. ${ }^{32}$ I guess maybe Gellhorn felt concern about depriving me of the experience with Stone, because he asked me whether I was interested in doing it the next year. I immediately said I would be interested, and within a short time and without another interview I got a letter from Stone that just sort of said "Dear Wechsler,"- -he was a last-name character-"Gellhorn tells me you might be interested in

they have won acceptance in the intervening years. The closed system has been opened; the rigidities and absolutes that interposed a barrier to change have been dispelled; the demand for what Max Radin called a "juster justice, a more lawful law" is not confined to academic cloisters. The battles of the thirties, preliminary though they were, have all been won upon a most impressive scale. What remains is the enormous task of nurturing the systematic and continuous refreshment of the law, an enterprise it is much easier to praise than to perform.

Id. at 5-6.

32. Walter Gellhorn (b. I906): Gellhorn, like Justice Stone, graduated from Amherst College as well as the Columbia School of Law. He clerked for Justice Stone during the 1931-1932 term and then joined the office of the Solicitor General in the United States Department of Justice. He returned to Columbia as an Assistant Professor in 1933. His teaching and research interests focused on administrative law, thus expanding the public law component of the Columbia curriculum. See Goebel, supra note 12, at 325-26. 
coming down with me for the next term. If that's so, l'd be delighted to have you." I just found this in my mail one morning.

Did working with Justice Stone and with the Court affect your thinking about the way the Court ought to decide cases?

I don't know that I can point to anything terribly concrete. I mean, we-my generation-were against the derivation of mandates from supposed constitutional sources, where the relation to the text, on the one hand, or to what could reasonably be asserted to be fundamental societal values on the other, seemed terribly attenuated. That was the main thrust of the critique of constitutional adjudication in the period of the Taft Court and before. I, at least, was a product of that critique, and people like Stone and Brandeis and Cardozo and Holmes, you know, these were the heroes of that crusade.

How do you think that Justice Stone would have reacted to Brown v. Board of Education ${ }^{33}$ and the cases following?

My sense of it is that he would have reacted adversely. I mean, New Englander that he was, abolitionist that he was, I think that would have seemed to him too sharp a break with the older tradition. He would have found it harder to see in racial segregation a discriminatory deprivation, since obviously the segregationist principle operates evenly on both sides of the excluded division.

That was a point I made in my Holmes lecture at Harvard, on the analytical side of the Brown case, and I don't repent that point. It really seems to me that the point on segregation is essentially that it's a denial of liberty, and it's a denial equally of the liberty of whites to associate with blacks, if those are the groups, and vice versa.

On the other side of it, the proposition that segregation is to be viewed as an invidious discrimination against whatever group is thought to be subservient-which is I guess what the Supreme Court held in Brown, or at least is the best way to state the holding in Brown, that gives it life for the future. I think we have not really assimilated this yet. The holding is not beyond the realm of casuistical controversy in its application. ${ }^{34}$

33. Brown v. Board of Educ,, 347 U.S. 483 (1954). For exhaustive treatment, see Richard Kluger, Simple Justice: The History of Brown v. Board of Education and Black America's Struggle for Equality (1976); see also Philip Elman \& Norman Silber, The Solicitor General's Office, Justice Frankfurter, and Civil Rights Litigation, 1946-1960: An Oral History, 100 Harv. L. Rev. 817, 831-41 (1987) (discussing Brown); Dennis J. Hutchinson, Unanimity and Desegregation: Decisionmaking in the Supreme Court, 1948-1958, 68 Geo. L.J. 1, 30-60 (1979) (detailing "inner history" of Brown Court's decisionmaking process). (1986):

34. See Geoffrey C. Hazard, Jr., Rising Above Principle, 135 U. Pa. L. Rev. 153, 185

[M]y reading of Professor Wechsler's lecture suggests that what he said was not quite what he was heard to say. What he actually said had primarily to do with the scope and implications of the ruling in Brown. As 1 read him, Professor Wechsler's point was that if blacks had a right not to be segregated, that implies 
But Stone might have been carried along to that, in the particular setting of those cases. The hardest one, of course, would have been the Topeka case, ${ }^{35}$ where, as you remember, the setup of the black school, the school for blacks, on the whole seemed to point to the conclusion that it was the better school in the complex. On the other hand, it did involve certain hardships for kids who were assigned there. Many of them had to be transported to go there, and of course, one of the ironies of all this is, you know, that in the argnment in the Topeka case, one of the points that was stressed was the hardship that was inflicted on black students. In having to be bused to the black school, they were denied the ease of access to the neighborhood school, which white kids had the benefit of. So to that extent, you know, this was struggling to find a discrimination in the setting.

It's quite instructive to go back and read the argnments of counsel in Brown and compare them with some of the extrapolations of Brown that are now part of the accepted doctrine in the area of the school business. It has been a very uneven and hardly adequately reasoned line of judicial development.

What do you think Stone would have done with Roe v. Wade?36

I think it could well have been congenial to Stone to find a substantive due process element, at least in the most restrictive type of state abortion legislation-that is, that which perceived a justification only when the termination of pregnancy was necessary to protect the life of the pregnant woman. He did write the Skinner case, which had to do with compulsory sterilization. ${ }^{37}$ And I don't think he would have had

that blacks had a right to associate with whites. If blacks had such a right of association, then on principles of equality-"neutral principles"-whites also had a right to associate with whites. But if white people wished to exercise this right by associating exclusively with whites, or with groups in which the number and kind of participating blacks was kept within the white people's limits of toleration, how could a right of free association be made available to both whites and blacks?

If this is what Professor Wechsler actually said, then it remains a fundamental challenge to the intelligibility and feasibility of some of the themes in Brown. These implications were foreseen by Professor Wechsler but realized by many others only twenty years later....

Id. (citations omitted). See also note 198 and accompanying text.

35. See Brown, 347 U.S. at $486,495$.

36. 410 U.S. 113 (1973). For discussions of the current abortion debate, see Mary Ann Glendon, The Transformation of Family Law: State, Law, and Family in the United States and Western Europe (1989); Laurence H. Tribe, Abortion: the Clash of the Absolutes (2d ed. 1992); Michael W. McConnell, How Not to Promote Serious Deliberation About Abortion, 58 U. Chi. L. Rev. 1181 (1991).

37. See Skinner v. Oklahoma ex rel. Williamson, 316 U.S. 535 (1942). Skinner held that an Oklahoma statute authorizing compulsory sterilization of habitual criminals, as applied to an individual convicted once of stealing a chicken and twice of robbery, violated the Equal Protection Clause of the Fourteenth Amendment. Justice Stone wrote a concurring opinion that endorsed the result in Justice Douglas' majority opinion but stopped short of reaching the Equal Protection Clause: "A law which condemns, 
any of the intellectual problems of the later Justices, who really, you know, started with the proposition that substantive due process had been completely exorcised.

So you don't think he would have been troubled by this as a resurgence of the old Lochner ${ }^{38}$ tradition?

I don't know how he would have voted. I think that, for example, it would have been quite clear that not only he but every member of the Court of the time I served as a clerk, with the possible exception of Justice Butler, would have held unconstitutional a statute that attempted to write into law Roman Catholic doctrine about abortion. That is, the absolute preclusion of intentional abortion, even if it meant the sacrifice of the mother's life to protect the fetus and a live birth. That would have been an easy case, I think.

Of course, that wasn't the law of any state ever, and it's interesting that even in heavily Roman Catholic constituencies, no state ever denied that if the chips were down-the choice had to be made-that the adult living person's interest could be preferred to the interest in the new life, the potential life.

When we were working on the Model Penal Code, we started there and began to ask ourselves, well, you know, what extensions really are there that on a similar balancing of values ought to be accepted? And of course we came up with that formulation which included not only the life of the mother, but the health of the mother-not only physical health, but mental health-the case where conception had been produced by rape or incest, and so on. ${ }^{39}$

That kind of thinking led to the easy-and the initial-liberalization of abortion laws in this country, contrary to some of the Cassandras in the American Law lnstitute who predicted that if we ever came out with anything like that, the Institute would be at an end. Within a year, we had fourteen states legislating to adopt our recommendations.

With respect to Roe, 1 think it's easy for me to see Stone's mind moving that way, and even finding a constitutional basis for it, but

without hearing, all the individuals of a class to so harsh a measure as the present because some or even many merit condemnation, is lacking in the first principles of due process." Id. at 545 (Stone, C.J., concurring).

38. See Lochner v. New York, 198 U.S. 45 (1905) (New York statute limiting the work day for bakers violated the Due Process Clause of the Fourteenth Amendment). See generally Paul Kens, Judicial Power and Reform Politics: The Anatomy of Lochner $v$. New York (I990) (detailing political, social, and economic history of Lochner).

39. See Model Penal Code $\$ 230.3$ (2) (Proposed Official Draft 1962). The MPC was largely adopted by the Criminal Code of Georgia in § 26-1202(a)(I)-(3) (current version at $\mathrm{Ga}$. Code Ann. $\S \S 16-12-140$ to $16-12-141$ (1992)); Georgia's version was struck down as unconstitutional in Doe v. Bolton, 410 U.S. 179 (1973). For a discussion of Bolton's treatment of the Model Penal Code provisions, see generally Richard A. Epstein, Substantive Due Process by Any Other Name: The Abortion Cases, 1973 Sup. Ct. Rev. 159. 
whether he could ever have been moved to subscribe to an opinion like Blackmun's opinion in the basic case, with the differentiation among the three trimesters and really a kind of inherently legislative drawing of lines-quite reasonably, I think, but inherently legislative in naturethere I have a sense that it's very unlikely that somebody like Stone could have subscribed to that.

Shortly after you retumed from your clerkship to Columbia, late in 1932, the New Deal began and new administrative agencies were being created. It would seem as though administrative law would have been the most exciting field to be in at the time. How come you moved toward criminal law instead?

Remember that $I$ had earlier done historical work with Professor Goebel in the criminal law field. My father did a lot of criminal work in practice, which I was very much aware of. I did my first Note as a Law Review editor on The Distinction Between Mala Prohibita and Mala In Se in Criminal Law, ${ }^{40}$ which was partly historical and partly analytical. So I guess that my imagination really was captured by criminal law as the area in which the ultimate sanctions of society were brought to bear on individuals. There was no course in criminal law at Columbia during my time. I had never had a course in criminal law.

So I had a combination of influences, and here was a real opportunity, not competing with somebody at the school already, and a new field, a fascinating field that needed to be attended to, was not drawing talent, generally thought to have no money in it, not really interesting to the bread-and-butter people.

On the most important choices you'll make in your life, you never will be confident that you know the reasons that led you. You'll make the choices and you hope that you'll be happy with the choices that you make, but if you try to think back-you know, "why did I do it?" This is very dubious speculation.

When I thought about going back to Columbia, the question was, what I would do. I had already started on federal jurisdiction, which was a hole in the curriculum that needed to be filled. Here was another one. And it was then suggested I go to work with Jerry [Jerome] Michael. ${ }^{41} \mathrm{I}$ had grown very fond of him when I was a student and had been his student. He and Karl Llewellyn and Julius Goebel were the three people I was friendliest with. They were good companions. They were nice people. That was a point too, on the basic choice. I liked these people.

In 1937 you wrote an article called A Rationale of the Law of Homicide. ${ }^{42}$ By the title it might be thought that you were reaching for some kind of

40. Herbert Wechsler, Note, The Distinction Between Mala Prohibita and Mala In Se in Criminal Law, 30 Colum. L. Rev. 74 (1930).

41. For biographical data on Michael, see supra note 30.

42. Herbert Wechsler \& Jerome Michael, A Rationale of the Law of Homicide: 1, 37 Colum. L. Rev. 701 (1937); Jerome Michael \& Herbert Wechsler, A Rationale of the Law of Homicide: II, 37 Colum. L. Rev. 1261 (1937). 
Langdellian synthesis of the case law. But it wasn't that kind of attempt, was it?

It definitely was not such an attempt, if you look at the article. The first part does provide a fairly articulate and simplified restatement of the rules as they had developed and existed, but the second and third parts confront each of the issues posed by the effort to delineate criminal, as distinguished from non-criminal, homicide, and then the differentiations drawn for purposes of sentencing, and face up to all the issues that structuring them involved. So it really was, 1 think, a quite pure, and somewhat overpure, effort to see whether one could lay on the table all the chips and all the cards, and try to build from there.

You stressed the project of the American Law Institute, which apparently had not yet proceeded very far to codify the criminal law. Were your thoughts at the time proceeding along lines that subsequently generated the Model Penal Code?

I was trying to influence the ALI effort, which then was starting out under absolutely terrible auspices and with literally fantastic conceptions. Fortunately, it was aborted, partly, 1 guess, because of Pearl Harbor. But if that damn thing had gotten going, in those days, with the background premises and the approach of the people that were involved, I really think that the result would have been disaster.

What was wrong with the premises and approach?

For one thing, the notion was somehow that the reordering of criminal law involved a great empirical exercise. In other words, they needed millions and millions of dollars in order to study something that you were going to go out into the world and look at and count. 1 never got very clear on what it was that you were going to count and look at, but the techniques of sociology were going to be all conscripted-as though this was going to increase your insight as to whether forcible sexual intercourse is something that a good society should try to protect people against, whether you have to count something in order to know that.

Did you see yourself as in revolt against utilitarianism?

No. On the contrary, 1 have always been exceedingly utilitarian in my views and approaches; but everybody knows that a social order that doesn't provide adequate protection for personal dignity and autonomy and bodily integrity is a defective social order. You don't have to count anything up in order to know that, nor do you need any sociological expertise or psychological expertise. Or any other kind of expertise.

Would it be fair to say that you were trying to offer an alternative to what the Institute was envisioning?

We were trying to show that by sitting down and thinking and following what 1 suppose one would call a method of philosophy - that is to say, a dialectical method of putting to oneself questions and coming up with answers, expounding problems and raising issues, discussing them-that one could make a good deal of progress towards systemization, clarification, and improvement. 
And I think that we demonstrated in the Model Penal Code that is just exactly what could be done by a systematic effort of that sort, which was empirical to the extent that one might hope that empirical information-even calling for specialized techniques for its acquisition-would be helpful.

Let me give you some illustrations, because this has been very abstract: The criminal law in our culture has always taken a dim view of sexual intimacy within particular degrees of consanguinity-essentially the incest problem. Well, why? I mean why should that type of conduct, if it isn't otherwise criminal, if it isn't forcible or doesn't involve corruption of youth, minors and so on, why should that type of bodily activity be criminalized? To begin with, there's a eugenic dimension to it, and anybody who's asking himself that question ought to know what the science of eugenics has to say on this subject, which is rather interesting and accessible. But obviously also, the eugenic dimension isn't the whole story, and so social workers have something to say that's useful about what happens in households in which this type of intimacy occurs-especially male parents and female offspring.

So you try to get all the information you can get. Now, it might be that the answer that you'd get would be that the damage done isn't sufficient to call for the type of intrusive preventative effort that is involved. On the whole, our culture tends to call the shot the other way, and most people are satisfied with calling it the other way. On the other hand, very barbarous penalties have been used, and so you get into that and learn something about that.

Or for another example, also within the sexual realm, consider the criminalization of adultery in America. It was quite characteristic of American criminal law to purport to criminalize adultery. Well, what kind of a criminalization is this? One thing I should think you'd want to know is: Do these criminalizations ever get enforced? Does anybody ever get prosecuted for adultery? It's rather interesting. In New York, the answer is no. At least when we were looking into it. In Boston, the answer was very definitely yes. So then you might want to know, well, who does get prosecuted, and under what circumstances?

These are all empirical matters, subject to the kind of helpful, pointed, empirical investigations that a sensible, practical person would undertake. But that isn't what the Institute was going to do.

Were you and Professor Michael cultural relativists-investigating principles of conduct without a priori standards for right and wrong?

Well, one certainly would want to learn anything that anthropologists had to teach, and this was our basic attitude, you see-whether information about other cultures or practices in this area would, in the end, prove helpful to you in functioning as a critic of the current norms, as reflected in law, or would seem to be unhelpful or irrelevant.

Did this make you, in that sense at least, something of a legal realist?

Well, certainly in the literal sense, yes. That is to say, in the sense 
that one approaches law not with the feeling that all the answers were dictated to Moses on Mount Sinai, or that some equivalent prescription occurred, but that you want to enrich your mind by anything that experience has to offer. In that sense, yes. But that, of course, is the broadest and least specific meaning of the term "Legal Realism."

If, on the other hand, you're turning to what Karl Llewellyn meant by realistic jurisprudence, in his article entitled The Call for a Realist Jurisprudence, ${ }^{43}$ then I become a little more doubtful, because the propagandists of a realist jurisprudence were all over the lot in terms of what they were for. They tended to be united only in terms of what they were against. They were against what I have called, in speaking to you, the closed system.

Karl Llewellyn, for example, never did get quite clear and develop very much through the years on how far he was essentially legislatively oriented in his effort, and how far he was essentially descriptively oriented. How far was he concerned, that is, with the accurate reportage of what courts and other organs of law administration were actually doing, and how far with why they were responding to specific issues or challenges or problems in the way that they were. And that split within what was roughly called the realist movement in jurisprudence was a very pervasive and deep one all through the period.

Consider, for example, the group that went to Johns Hopkins-the Oliphant group. At least if you take seriously what they wrote, these people seemed to think that what was needed was more accurate reportage-the tools with which to make definite descriptions, more meaningful descriptions than judicial opinions would contain, of what judges were doing in resolving controversies and why they were resolving them the way they were. As if the ultimate purpose of the enterprise was to facilitate a more accurate prediction of what judges would decide-you know, going back to the Holmes predictive theory of what judges would do. And this to them was law, you see.

Now there are very, very few contexts in which that type of realist jurisprndence is worth a fig. Partly because, as Morris Cohen ${ }^{44}$ never

43. See Karl N. Llewellyn, A Realistic Jurisprudence-The Next Step, 30 Colum. L. Rev. 431 (1930).

44. Morris R. Cohen (1880-1947): Cohen earued a B.S. from City College of New York in 1900, and after studying at Columbia, received the Ph.D. in philosophy from Harvard in 1906. In 1912 he joined the Philosophy Department at City College and remained there until his retirement in 1938. See Morris R. Cohen, A Dreamer's Journey: The Autobiography of Morris Raphael Cohen 15, 89, 93, 131, 143 (1949); David A. Hollinger, Morris R. Cohen and the Scientific Ideal at ix-xi (1975); Lenora C. Rosenfield, Portrait of a Philosopher: Morris R. Cohen in Life and Letters at xiv-xv, 67,69 (1962). Cohen supplemented his formal work with essays on legal and social philosophy aimed at a more general audience. It was in these essays that he criticized the legal realists. Cohen conceded that judges not only found but also made law and that empirical research had an important role to play in legal scholarship. However, he was troubled by "the theoretical problems realism created" and insisted that "some 
tired of pointing out, the facts changed faster than the reporters could write up their reportage of the facts. And anyhow, as a means to prediction, you couldn't control variables enough to really improve predictive capacity much that way.

The part of the movement that was vital and significant was the part that focused not on more accurate empirical description, but on better normative determination. And there it was a matter simply of displacing the closed system view, of recognizing legislative changes, of marshalling the facts that had a bearing on the wisdom of legislative choices. This is the common-sense approach-call it utilitarian, if you will-but when you get down to ultimate value choices, it doesn't help very much.

The important point is to be aware of what the value choices are, and so far as possible, to be able to articulate the reasons that lead to choosing A rather than B. Why? So that accurate statement can enable the next person to know whether he or she goes with you or against you. And in the end-in a democracy, of course-the voters will, if they're informed, be determinative, so that in that sense, the whole thing is utilitarian.

Do you think that the value choices embodied in the law during the period you've been talking about are still true for society in our period now, or were only true in the earlier period we've been talking about here? Or are they true, on the other hand, in some universal sense?

I don't salivate to these dichotomies, I must confess-perhaps because of the limitations of imagination. I mean, I've always been content myself to face the questions for here and now and, when I encounter settings in which the very different choices seem to have been made with satisfaction, to try and ponder why, and why the satisfaction. And criminal law is, you know, quite an inviting area for that sort of exercise. Over and over again, one encounters things that got settled in the law that from current perspective seem candidates for being rapidly unsettled, and yet one has to ask: Well, why did they become settled? What were the influences that were predominant? And sometimes, if you push yourself hard enough and ask questions of that order, you learn things about the current situation that you were tending to ignore.

Do you feel that the court-packing plan proposed by President Roosevelt in $1937^{45}$ and the change in direction that the Supreme Court took following that event amounted to a constitutional revolution against the closed system on the Court?

Yes, I certainly do. I think Jones $\mathcal{E}$ Laughlin was a revolution, a con-

supralegal moral standard was necessary as the basis for moral judgments." Purcell, supra note 19, at 177 .

45. See William E. Leuchtenburg, The Origins of Franklin D. Roosevelt's "CourtPacking" Plan, 1966 Sup. Ct. Rev. 347, 347. 
stitutional revolution. ${ }^{46}$ And, don't forget, the Social Security Act was also sustained. ${ }^{47}$

In later years, fervent revolutionaries sometimes come to regret the results of those revolutions. Has that been the case with you?

No, not this revolution we're talking about. No, 1 think that the denial to Congress of the power to legislate on a national basis to meet national economic problems is simply catastrophic. That's not to say that 1 think that everything that Congress has enacted is wise.

Some people would view as a corollary to that, that the Court does have a greater role to play in invalidating statutes which impinge on insular minorities, or interfere with political rights and civil liberties. Is that also a part of the revolution you supported?

Well, that's not really part of this revolution, but rather it is affected by it. The thrust of the change to which 1 was alluding was surely to get legislative elbow room for Congress in dealing with national economic problems. A kind of elbow room that one would suppose the Commerce Clause was meant to give Congress.

Now the First Amendment aspect of the matter, which was after all what we were dealing with in the Herndon case, ${ }^{48}$ emerged as a difficult problem insofar as it posed the issue whether you could consistently defend and support legislative elbow room in the ordering of the economy, and simultaneously urge strict scrutiny in the interest of individual autonomy and freedom in the noneconomic areas of life. That, too, was a soul-searching issue, and very much in the forefront of legal development at the time when we were working on the Herndon case.

1 think the kind of recognition of the issue that you have in the Carolene Products footnote ${ }^{49}$ reflects the conflict and ambivalence that one felt about that. One had to satisfy oneself that there were strong affirmative reasons for supporting a judicial negative in the one case, when you rejected it in the other.

It marked the maturation of our constitutional thought in this cen-

46. NLRB v. Jones \& Laughlin Steel Corp., 301 U.S. 1 (1937) (sustaining a National Labor Relations Act provision protecting the collective bargaining rights of workers not directly engaged in interstate or foreign commerce). Professor Currie views Jones $\mathcal{E}^{\circ}$ Laughlin as "the real breakthrough" in the judicial New Deal. See David P. Currie, The Constitution in the Supreme Court: The Second Century, 1888-1986, at 236 (1990).

47. See Helvering v. Davis, 301 U.S. 619, 640 (1937).

48. See Herndon v. Lowry, 301 U.S. 242 (1937).

49. See United States v. Carolene Prods. Co., 304 U.S. 144, 152 n.4 (1938) (suggesting that court would apply stricter scrutiny to legislation affecting minority rights or interfering with the political process than it would to economic regulation). Carolene Products continues to spark debate and controversy. For a sampling, see Louis Lusky, By What Right?: A Commentary on the Supreme Court's Power to Revise the Constitution 108-12 (1975); Bruce A. Ackerman, Beyond Carolene Products, 98 Harv. L. Rev. 713, 740-46 (1985); Robert M. Cover, The Origins of Judicial Activism in the Protection of Minorities, 91 Yale L.J. 1287, 1290-92 (1982); Geoffrey P. Miller, The True Story of Carolene Products, 1987 Sup. Ct. Rev. 397, 428. 
tury when the Court did begin to articulate such reasons. And that they have come to prevail, perhaps even to prevail somewhat more strongly than they ought to prevail, does represent a revolution, to be sure, but it's a second revolution. It's later in time. You really don't come to it until you've achieved the first revolution. Then you have to ask yourself, well, what does this mean for freedom of speech?

It is helpful that one can't read the record-sparse though it is, to be sure-of the congressional development of the Fourteenth Amendment, without being persuaded that the people who were in charge of it, though they didn't quite understand what they were doing and never adequately explained what they were doing, did bave a sense that they were imposing on the states an obligation to respect the fundamental rights of persons. It's been a long struggle to gain even a decent sophistication of approach to the problem of defining what those fundamental rights are, or how one goes about looking for them. ${ }^{50}$ But it's not the first time or the last that we will have written into law a generalization, the specific content of which we're by no means agreed upon.

Would it be fair to say that your preparation of new teaching materials in criminal law before the Second World War, and in federal jurisdiction after the War, was part of a conscious effort to break down the closed system values?

Yes, and to develop pedagogical materials that meant that it was more than a matter of classroom dialogue, but that you were handing the student material that invited cogitation outside the closed system, and I would say that was really the dominant effort of my pedagogical existence. Unnecessary now. Nobody thinks anymore in terms of the closed system.

\section{HaRd Assignments and Resigning Issues}

Between 1933 and 1939, Professor Wechsler associated himself with several legislative initiatives of the Roosevelt New Deal. He accepted a position as a National Recovery Administration Code Representative, helping to enforce industry-wide wage, price and quality regulations; he regretted deeply the Supreme Court's 1935 decision in Schecter Poultry51 that struck down the NIRA and "solidified the worst in the limitations on the national commerce power that the decisions of the Supreme Court had imposed."52

Professor Wechsler also participated in important civil liberties litigation during this period. Together with Jerome Michael and Walter Gellhorn, he took a

50. For a discussion of both the framing of the Fourteenth Amendment and the subsequent struggle to give the text a coherent meaning, including the rise and fall of substantive due process in the Lochner Era, see William E. Nelson, The Fourteenth Amendment: From Political Principle to Judicial Doctrine (1988); see also 7 Charles Fairman, History of the Supreme Court of the United States: Reconstruction and Reunion 1864-88, Part Two 133-36 (1987).

51. Schecter Poultry Corp. v. United States, 295 U.S. 495 (1935).

52. Oral History, supra note 1 , at 123. 
leading role in formulating the Supreme Court argument in the Herndon case, 53 involving a black Communist Party organizer who had been convicted by the State of Georgia of attempting to incite insurrection. ${ }^{54}$ The Supreme Court held that the insurrection statute, as construed and applied by the Georgia authorities, "amounts merely to a dragnet which may enmesh anyone who agitates for a change of government" and, accordingly, was so vague as to violate the guarantee of liberty protected by the Fourteenth Amendment. ${ }^{55}$ In so holding, the Court accepted the argument that the First Amendment, as incorporated into the Fourteenth Amendment's Due Process Clause, prohibited unreasonable restrictions on freedom of speech and assembly. 'I've never joined in the repudiation of substantive due process," Wechsler stated, "and I don't think that the people who drafted the Fourteenth Amendment would have been outraged by the concept."56

In 1937 Professor Wechsler was invited by Senator Wagner, the Democratic leader in New York State's 1938 Constitutional Convention, to head Senator Wagner's Convention staff. He worked on constitutional aspects of providing housing and other benefits for low income people, which was still a new concept in 1938. He also worked to strengthen the state's bill of rights in areas such as freedom of speech and assembly, and unreasonable search and seizure. Until Wechsler left for Washington in 1940, he devoted at least half his time to teaching at Columbia, and spent much of the remainder on pro bono publico legal activities.

In 1940 I went to Washington on a sabbatical from Columbia, having recently finished the criminal law casebook, on an invitation from the Assistant Attorney General in charge of the Criminal Division. I was to join the Criminal Division and work there on various projects that he had in mind for the improvement of the federal criminal law. As it worked out, because of politics in the Justice Department, I did not go into the Criminal Division, but instead I went into the Solicitor General's office. I spent that year arguing cases in the United States Supreme Court. I argued five cases that were full arguments, including United States $v$. Classic, ${ }^{57}$ which was one of the important cases of the term, and which I won by one vote. At the end of that year of arguing cases, and even more so of superintending briefs, the question was what I would do with myself.

Of course, the big thing that had happened was that on December 7,1941 , the world had changed, and so, where Columbia would have probably been quite insistent that I get back for the ' 41 -'42 semester,

53. See Herndon v. Lowry, 301 U.S. 242 (1937). Whitney North Seymour delivered the argument, with Wechsler on the brief. See Lowry, 301 U.S. at 243. The case came to the Court on appeal from the denial of relief on a petition for a writ of habeas corpus in the Georgia courts. The Court had earlier denied a direct appeal from the conviction on the ground that no federal question had been raised. See Herndon v. Georgia, 295 U.S. 441, 446 (1935). See generally Thomas, supra note 8 (constructing a "cultural history" of the political events surrounding Herndon).

54. See Lowry, 301 U.S. at 245-46.

55. Id. at 263-64.

56. Oral History, supra note 1 , at 136 .

57. 313 U.S. 299 (1941). See supra text accompanying note 9. 
nothing could have been more congenial to the Columbia brass than that I would not come back.

I would have been glad to stay in the SG's [Solicitor General's] office. I liked the SG and I liked the life. What's more, at the end of that term of Court, Chief Justice Hughes resigned, Justice Stone was appointed Chief Justice, Attorney General [Robert] Jackson was appointed to succeed Stone, and Francis Biddle was appointed Attorney General to succeed Jackson. ${ }^{58}$ Having developed in that year not only a close professional association, but a personal friendship with Biddle, it was entirely congenial to me to plan to stay in the Department of Justice.

However, the Reed Committee ${ }^{59}$-Justice Stanley Reed-which had been appointed by the President, filed a report recommending that a Civil Service be established for lawyers in the Federal Government, but not under the regular Civil Service Commission. This being a professional service, to be successful it would have to be run by lawyers. The problem was to work out a merit system-with tenure and the like, but without the written examinations of the sort that the Civil Service Commission used for other, more routine assignments. Take politics out and provide a certain protection of tenure, and attempt to draw talent to the service of government.

Biddle was very much interested in this, and he invited me and prevailed on me to take the post of Executive Secretary of this Board, which was called the Board of Legal Examiners. ${ }^{60}$ It was set up in the Civil Service Commission, but was actually independent of the Commission in the sense that the Board members were appointed by the President and it appointed its own staff.

Well, we developed a system of oral examination, which I think worked reasonably successfully. What we did was to say that we would not select people for appointments, but if a department head-General Counsel to the SEC, say-had a lawyer whom he wanted to appoint, he would submit the nomination to us for an endorsement of the person's qualifications, and we went about testing qualifications through a panel of our Board, undertaking what amounted to a long interview with the individual, in which questions, hard questions, would be put to him or her.

58. See David M. O'Brien, Storm Center: The Supreme Court in American Politics 73-74 (1986); Biddle Is Named to Cabinet Post, N.Y. Times, Aug. 26, 1941, at 1.

59. See Frank L. Kluckhohn, More Federal Jobs Under Civil Service Asked of Congress, N.Y. Times, Feb. 25, 1941, at 1.

60. The Board of Legal Examiners was created within the Civil Service Commission by executive order on April 23, 1941. See Exec. Order No. 8743, 3 C.F.R. 927 (1938-1943), amended by Exec. Order No. 9230, 3 C.F.R. 1201 (1938-1943). In a subsequent Order, President Roosevelt vested the Commission with "administration of the civil service laws in their application to attorney positions in the classified civil service and to the incumbents of such positions." Exec. Order No. 9358, 3 C.F.R. 256, 256 (1943-1948). 
Such as?

1 might say to you, Mr. Lawyer, what was the last case that you argued in an appellate court? And you would then describe a case to me, and that would initiate a dialogue in which I would interrogate you about the case that you argued. Well, now, a lawyer might be offended by the notion that in order to get a job with the federal government, he has to go and study Torts again. But he couldn't be offended by the idea that he should be asked to give a sensible and informative and accurate account of a case that he handled last week for a client.

And so we developed this technique to I think quite an art. Its mere existence had an effect on appointments. I mean, the fellows just lurking in the corridor waiting to get appointed now pulled out, because they knew they couldn't show up. A great deal of weight, of political pressure, was lifted, we were told by the chief law officers of government, by the fact that they knew that they couldn't put this mug up without disgracing themselves.

The net of it was that the great expansion that was necessary in the immediate aftermath of Pearl Harbor was able to be accomplished through this relatively inoffensive type of procedure, and still a reasonable level of competence maintained. This entity served to achieve the enlargement of the federal legal service by probably two or three hundred percent, as was badly needed at that time. For example, we had to clear all the legal appointments to the OPA and the War Production Board, not to speak of the old line departments and commissions. It would have been a very serious loss to the government if either the patronage system or routine civil service had been left free to handle the situation.

This program was never popular with the Civil Service Commission, which regarded it as an intrusion on its autonomy. For the opposite reason it was never popular in Congress, where it was regarded as an intrusion on political patronage. So from the very beginning, we were in constant appropriations trouble.

The first time I went up to Congress to be questioned as Executive Secretary, it fell to me to handle the burden of appearing at an Appropriations hearing. Congressman Starnes, Joseph Starnes, ${ }^{61}$ of Alabama, a member of the Dies Committee, ${ }^{62}$ went after me as a Com-

61. Joseph Stames (1895-1962): Starnes served as a Democratic Representative from Alabama from 1935-1945. Congressman Starnes was a member of the Special House Committee Investigating Un-American Activities. See Joe Starnes Dies; Ex-House Member, N.Y. Times, Jan. 10, 1962, at 47.

62. The "Dies Committee," as the House Committee on Un-American Activities, led by Congressman Martin Dies of Texas, was popularly known, was a predecessor to the congressional committees that investigated allegedly subversive activities during the 1950 s. It was formed "to investigate subversive and un-American propaganda." See Walter Goodman, The Committee: The Extraordinary Career of the House Committee on Un-American Activities 24-58 (1968). 
munist, as indicated by my role in the Herndon case, and also in a second Communist case that had been in the Supreme Court a year or two later, the Strecker case. ${ }^{63}$ Joseph Strecker was an ex-Communist, and the legal question concerned whether under the statutes aliens who had been members of the Communist Party were subject to deportation, whether or not they were still members. Walter Gellhorn and I did the brief and Whitney Seymour argued the case. ${ }^{64} \mathrm{He}$ argued it against Bob [Robert] Jackson, who was then Solicitor General. And we won hands down in the Supreme Court.

So I had two strikes against me, the Herndon case and this. Both cases in which we had prevailed. In other words, we had the Supreme Court's certification that our legal contentions were correct, and still this was thought to be an indication of dubious loyalty on my part. According to a friend of mine, Joe Starnes had said: "I wouldn't feel so deeply about it if he'd taken a fee for his services." He didn't think it was possible that I could have done this work out of anything other than identification with Communists. Why he would have thought that would lead me to be helpful to an ex-Communist, I'm not quite clear.

Did the Examiners program get funded?

We eventually did get our appropriations and we did carry on during the period of a year-plus that I stayed with it. I built up a staff. A few years later the Board went out of existence, and lawyers were removed from the Civil Service.

When I left, it was because Francis Biddle, who by that time had become Attorney General, wanted help in connection with the general administration of the Department of Justice. He offered me a place as Assistant to the Assistant to The Attorney General, who would now be called the Deputy Attorney General. Jim Rowe ${ }^{65}$ had been The Assistant to the Attorney General. He had come to that office from the White House-where he'd been one of FDR's so-called anonymous secretaries. He was going into the Navy and there was going to be a change in the Deputyship. I think Biddle felt that he'd get more continuity if somebody like me, who'd been there for a while and was close to him, was there.

So I went into the Attorney General's office, serving as Deputy to Jim Rowe first. When Rowe went into the Navy, his place was taken by James McGranery, ${ }^{66}$ a Congressman from Philadelphia who had been a

63. See Kessler v. Strecker, 307 U.S. 22 (1939).

64. See id. at 27-28.

65. James Henry Rowe, Jr. (1909-1984): After graduating from Harvard Law School and serving as secretary to Justice Oliver Wendell Holmes, Rowe held positions with several of the New Deal agencies, with the President's campaign staff, and as a secretary to the President. He served as Assistant Attorney General in the Department of Justice from 1941-1943. See Seth S. King, James Rowe, New Deal Aide and an Assistant to Roosevelt, N.Y. Times, June 19, 1984, at B10.

66. James Patrick McGranery (1895-1963): McGranery was appointed The Assistant 
mild friend of Biddle's for some years. McGranery's was the office that had primary responsibility for congressional relations, judicial appointments, the United States Attorney appointments, overall administrative supervision of the Department, and a considerable role in relation to legislation.

So all of the sudden I was thrown into the real guts of the tough stuff going on in the Department.

What was the hardest job you were given?

The toughest War Division assignment I think I ever had I got through Biddle from the White House in 1943, in anticipation of the presidential election of 1944. The problem was to formulate a solution to the potential disenfranchisement of the ten million Americans who were overseas or otherwise out of reach of the ordinary absentee ballot provisions of the state voting laws.

This was politically sensitive?

Of course. The Republicans didn't want the ten million people to vote, because they figured, quite properly, that the vote would be preponderantly Democratic. And I think they were right. From the Southern point of view, however, there was an additional wrinkle-the fear that this was an opening wedge for congressional intrusion in the electoral process, with its ultimate implications for breaking down the disenfranchisement of blacks. And the Southerners were absolutely right about that.

Now some preliminary work had been done by a very able young lawyer named Ernest Jennes, ${ }^{67}$ but Biddle asked me to take it in charge. It involved working with a group drawn from the War Department, and the person representing the War Department was a Colonel, named Bobby [Robert] Cutler, 68 who later became the Chairman of the National Security Council during the Eisenhower Administration. From the Navy Department, there was Adlai Stevenson. One other person who participated was Oscar Ewing, ${ }^{69}$ Jack Ewing as he was called,

to the Attorney General in November, 1943, a position he held until 1946. He served as Attorney General between March, 1952, and January, 1953. See James Patrick McGranery, N.Y. Times, Apr. 1, 1963, at 36.

67. Emest W. Jennes (b. 1917): A 1942 graduate of Yale Law School, Jennes worked in the Justice Department during the war and later became a partner specializing in communications law at the Washington, D.C., firm of Covington and Burling.

68. Robert Cutler (1895-1974): A banking executive, Cutler graduated from Harvard Law School in 1922. He worked on special assignments for Secretary of War Henry L. Stimson and General George C. Marshall during World War II. He vigorously represented President Eisenhower on the National Security Council from 1953-1955 and in 1957-1958. See Robert Cutler Is Dead at 78; Aided Eisenhower on Security, N.Y. Times, May 10, 1974, at 40; see also Robert Cutler, No Time for Rest (1966) (memoir).

69. Oscar Ross Ewing (1889-1980): Ewing graduated from Harvard Law School in 1913. Mr. Ewing served as Assistant Chairman of the Democratic National Committee from Augnst, 1940, through May, 1942, and was appointed Vice Chairman of the 
who was Counsel, later Chairman, of the Democratic National Committee. When somebody asked him what he was doing at one of our meetings, he said he was "counsel to the situation."

In any event, I did draft a bill, ${ }^{70}$ the essence of which was to authorize the War and Navy Departments, under the administrative direction of a War Ballot Commission, to print up ballots containing the names of principal candidates for President and Vice-President, to distribute these ballots overseas, collect them, and return them to the voting districts of the individual service person, with a statutory mandate on the state electoral authorities to count the votes so cast. ${ }^{71}$

Was it a delicate constitutional problem to justify the procedure?

You can see what an enormous dislocation this would have effectuated in a period when state control of the electoral franchise was felt to be a first principle in American law and politics, either under Article I, in connection with congressional elections, the Seventeenth Amendment, in connection with senatorial, and Article II, in connection with presidential elections.

We had to argue that the war power, which previously had been held, for example, to permit Congress to put a moratorium on the foreclosure of mortgages representing the obligations of service personnel, sustained the power of Congress to protect the rights of military personnel to vote-that the war power included a power to prevent or remedy dislocation produced by the legitimate exercise of national powers in the fighting of the war, and that the same principle operated to permit Congress in its wisdom to prevent service personnel from being required by state law to lose the benefit of the franchise conferred by state law.

The principal people I worked with in the Senate were Senator Theodore Green of Rhode Island, ${ }^{72}$ who was Chairman of the Senate Committee on Privileges and Elections, and Senator Scott Lucas of Illinois; ${ }^{73}$ and in the House, a congressman by the name of Francis Worley. ${ }^{74}$

Committee in August, 1942. See Thomas W. Ennis, Oscar R. Ewing, 90, Truman Aide, Dead, N.Y. Times, Jan. 9, 1980, at D21.

70. See Absentee Voting in Time of War, Pub. L. No. 78-277, 58 Stat. 136 (1944) (repealed in full 1955).

71. See id.

72. Theodore Francis Green (1867-1966): Democratic Senator from Rhode lsland (1937-1961). Green chaired the Committee on Privileges and Elections during the 77th through 79th Congresses. He served as Governor of Rhode 1sland from 1933-1937. See Theodore F. Green Dies at 98; Ex-Senator from Rhode Island, N.Y. Times, May 20, 1966 , at 47.

73. Scott Wike Lucas (1892-1968): Representative and Senator from Illinois. A liberal Democrat, Lucas served in the House of Representatives from 1935-1939, and in the Senate from 1939-1951. See Scott Lucas Dies; Ex-Senate Leader, N.Y. Times, Feb. 23,1968 , at 33 .

74. Francis Eugene Worley (1908-1974): Worley represented Texas as a Democrat in 


\section{Who opposed you?}

Our principal opponent was Senator [Robert] Taft, who was himself, of course, a Republican hopeful in the 1944 election, and who was enough of a lawyer to undertake to try to differentiate the foreclosure situation and others. ${ }^{75}$ His theory was that there's a difference between affecting unspecified reserve powers of the states and tampering with powers that the Constitution itself explicitly confers upon the states. Well, why one should see that distinction was never explained.

In the House, my principal opponent was one of the most miserable characters I think I've ever encountered in this life, a congressman from Mississippi by the name of John Rankin. John Rankin was certainly one of the most totally racist, prejudiced people to come to Congress, even in those days, from anywhere in the country. ${ }^{76}$

In any event, there was a bitter, bitter, bitter fight about the serviceman's franchise issue. The opponents of the bill came up with a competing bill that left the choice and initiative to the states-only if a state asked the War Department and Navy Department to distribute the ballots would the machinery be activated. This was a shrewd alternative.

At one point, after the alternative had been put forward by the opposition, we read in the newspaper, much to our regret and horror, that the President had sent a special message, on the soldiers' voting issue, in which he denounced this competing bill as a "fraud." Well, the response on the Hill was simply white hot. I mean, there are just certain things that $I$ think even today are not done in national politics, and one of them is for the President to call a proposal a fraud. 1 mean he can denounce it, he can oppose it, he can say all kinds of bad things about it. But to in effect charge that those who are pushing it are crooks or thieves is impermissible. That's probably a good convention.

the House of Representatives from 1941-1950. A graduate of the University of Texas Law School, he served as Chairman of the Committee on the Election of President, Vice President, and Representatives during the 78th Congress. Worley later became Chief Judge of the U.S. Court of Customs and Patent Appeals. See 58 National Cyclopedia American Biographies 64-65 (1979).

75. Robert A. Taft (1889-1953): The son of President and later Chief Justice Taft, Robert A. Taft was a leader of the Republican Party and a highly influential Senator from Ohio (1939-1953). Taft was labeled a partisan isolationist by critics, but supporters viewed him as a nationalist concerned about America's ability to solve problems effectively worldwide. Three times a contender for the Republican presidential nomination, Taft never succeeded, in part due to his very conservative and isolationist image. He served as Senate majority leader from 1953 until he died of cancer at the height of his influence. See James T. Patterson, Mr. Republican: A Biography of Robert A. Taft 263-64 (1972).

76. John Elliott Rankin (1882-1960): After working for a newspaper, Rankin graduated from the law department of the University of Mississippi in 1910 and subsequently served as a prosecutor and a lecturer. Rankin served in the House of Representatives from 1921 through 1953. See John Rankin Dies; Ex-Legislator, 78, N.Y. Times, Nov. 27, 1960, at 86. 
Roosevelt deliberately violated it. ${ }^{77}$

Of course, it was immediately asserted on the Hill that I had drafted this message, because it was known that I had drafted the bill and that I'd written most of the speeches that were given by Senator Green and Senator Lucas and Congressman Worley in support of the bill.

And it was my fortune to be nominated to be Assistant Attorney General, in charge of the War Division, almost immediately after the President had delivered his "fraud" message.

An inauspicious moment?

Yes. I understand that Rankin got word that the nomination was coming, and just as soon as the clerk read the name, Rankin rose in the House and denounced me. He said I was that fellow "Weshler, who calls himself Wechsler." And this appears in the Congressional Record. ${ }^{78}$ There was a family in Washington, Adam Wechsler, which was not a Jewish family, and the implication was that I had changed my name from a Jewish-sounding name to a non-Jewish sounding name. This was still a period of stereotypes in matters of that kind.

Well, they managed to hold up my confirmation in the Senate for the better part of two-and-a-half or three months. I think I was nominated about the end of February, and I was confirmed the first week in May. ${ }^{79}$ During those intervening months I must say I spent rather an unpleasant time. Not that I cared very much one way or the other about the job, but that I felt really that my standing and integrity were at issue. I found it difficult to take Biddle's line that it was just a matter of politics. I think now maybe I could. It's much easier to take that line at my age than it is if you're in your thirties.

What problems did you confront when you became Assistant Attormey General in charge of the War Division?

The War Division had a mixed jurisdiction. It was in charge of all alien enemy internments and litigation with respect to them. It was in charge of all problems growing out of the evacuation of Japanese from the West Coast to the relocation centers, as they were called, in which they were living. It was concerned with all problems involving foreign agents' registration in the United States, and with all problems involving the assertion of military controls over civilians. That included, for example, martial law in Hawaii, and the efforts by commanding generals in this country to order people out of areas-the subordinate program to the large scale evacuation of Japanese. Then I was in charge of

77. See C.P. Trussell, President Calls Vote Bill 'Fraud'; 'Insult,' Says Taft, N.Y. Times, Jan. 27, 1944, at 1.

78. See 90 Cong. Rec. 1087 (1944) (remarks of Rep. Rankin).

79. Wechsler was nominated by President Roosevelt on February 4, 1944; he was sworn in by Attorney General Biddle on June 23 of that year. See Wechsler Is Promoted, N.Y. Times, Feb. 5, 1944, at 8; Becomes Assistant to Biddle, N.Y. Times, June 24, I944, at 13. 
a very. large scale study program-a plan Thurmond Arnold ${ }^{80}$ had invented involving industrial concentration in enemy countries-with a view to providing intelligence to the military service for help in the selection of bombing targets. Those were the principal heads of jurisdiction, but there was also a final miscellaneous category of great importance consisting of any other problems growing out of the war that were not within the routine assignments of other divisions.

You mentioned having jurisdiction over the relocation of Japanese citizens on the West Coast. Did you have doubts about the constitutionality of that matter?

Yes, indeed I did, and we all did in the Division. But we wrote the briefs in support of first the curfew, and then the expulsion and relocation orders. First the Hirabayashi ${ }^{81}$ case (before my time), then the Korematsu ${ }^{82}$ case, in which I was very much involved. And we also wrote the unsuccessful brief supporting the validity of the continuation of martial law in Hawaii. ${ }^{83}$

These were nice cases for testing the role of the government lawyer. The thing about those briefs is that they declined to make arguments that the War Department in particular wanted to be made, which we considered to be specious, either in law or in fact, the primary importance being refusing to make argnments that were specious in fact, because those are the arguments that can mislead a court. The War Department had an entirely misguided conception of what the record was in the Korematsu case. We did not, for example, attempt to draw any strength from the Commanding General's report, because we regarded it as spurious. ${ }^{84}$

80. Thurman Wesley Amold (1891-1969): Arnold was a professor of Law at Yale University from 1930-1938, advised President Roosevelt on anti-trust matters, served briefly as a federal appeals court judge, and was a founder of the Washington firm of Arnold \& Porter. Among other works, Professor Aruold wrote The Folklore of Capitalism (1937). See 5 Who's Who in America 1969-1973, at 101 (1973).

81. See Hirabayashi v. United States, 320 U.S. 81 (1943).

82. See Korematsu v. United States, 323 U.S. 214 (1944). In 1984, Fred Korematsu, the party in the original Korematsu case, obtained a writ of coram nobis from a U.S. District Court in California wiping out his original conviction on the ground that it had been obtained in reliance on a selective and distorted factual record. See Korematsu v. United States, 584 F. Supp. 1406 (N.D. Cal. 1984).

83. See Duncan v. Kahanamoku, 327 U.S. 304 (1946).

84. John L. DeWitt, the Commanding General of the Western Defense Command (which included California and other western states), issued a report justifying the evacuation dated June 5, 1943, which became public in January, 1944. Among other things, General DeWitt claimed that Japanese-Americans were engaged in extensive illegal radio signalling and shore-to-ship signalling, with the clear implication that these individuals were committing overt acts of treason against the United States. Responsible officials in the Department of Justice knew these claims to be outright fabrications. See Korematsu, 584 F. Supp. at 1421-24 (reproducing internal Justice Department memoranda).

General DeWitt's report created severe problems for the Department of Justice in preparing its brief in the Korematsu case. In page proofs, the brief contained a footnote stating that "[t]he recital [in the DeWitt Report] of the circumstances justifying the 


\section{So, at least when the issue was presented to the Court and argued}

evacuation as a matter of military necessity . . . is in several respects, particularly with reference to the use of illegal radio transmitters and to shore-to-ship signalling by persons of Japanese ancestry, in conflict with information in the possession of the Department of Justice. In view of the contrariety of the reports on this matter we do not ask the Court to take judicial notice of the recital of those facts contained in the Report." Id. at 1423. A late revision by Solicitor General Charles Fahy modified the footnote to state that the assertions in the DeWitt Report were inconsistent with the "views" of the Department of Justice, rather than with "information in the possession" of the Department. Id. at 1423-24. (See infra note 85 for biographical information of Solicitor General Fahy.)

Subsequently, the brief was modified still further, apparently at the request of the War Department. The brief that the Supreme Court received from the Attorney General's Office included a footnote stating:

The Final Report of General DeWitt (which is dated June 5, 1943, but which was not made public until January 1944), hereinafter cited as Final Report, is relied on in this brief for statistics and other details concerning the actual evacuation and the events that took place subsequent thereto. We have specifically recited in this brief the facts relating to the justification for the evacuation, of which we ask the Court to take judicial notice, and we rely upon the Final Report [of the Commanding General] only to the extent that it relates to such facts.

Brief for the United States at 11 n.2, Korematsu v. United States, 323 U.S. 214 (1944) (No. 44-22). The brief for the United States urged affirmance of the appellate court determination that the removal was a valid exercise of the war power "because of the military situation . . . coupled with the danger from a disloyal minority and [because] the difficulty of segregating these from other persons of Japanese ancestry constituted a substantial basis of the military decision that the exclusion was a necessary military measure." Id. at 17. On the brief for the United States were Fahy, Wechsler, Edward J. Ennis (Director of the Alien Enemy Control Unit) and Department attorneys Ralph F. Fuchs and John L. Burling. See id. at 59.

The historical record shows that Wechsler received a number of memoranda from subordinates in the War Division protesting the revisions to the footnote in which the Department softened its repudiation of the DeWitt Report. See Korematsu, 584 F. Supp. at 1421-24 (reproducing internal Justice Department memoranda). For a critical analysis that emphasizes Wechsler's influence on the final form of the footnote, see Peter Irons, Justice at War 278-92 (1983) (expressing the view that the footnote offered only a hint of doubt about the War Department's Report justifying the relocation policies).

Justice Black's majority opinion in Korematsu affirmed the constitutionality of the exclusion of American citizens of Japanese ancestry, including Fred Korematsu, from Alemeda County in California by upholding the judgment "that exclusion of the whole group was a military imperative" under the War Power Clause of the Constitution. See Korematsu, 323 U.S. at 219 . Justice Black wrote:

Korematsu was not excluded from the Military Area because of hostility to him or his race. He was excluded because we are at war with the Japanese Empire, because the properly constituted military authorities feared an invasion of our West Coast and felt constrained to take proper security measures, because they decided that the military urgency of the situation demanded that all citizens of Japanese ancestry be segregated from the West Coast temporarily, and finally, because Congress, reposing its confidence in this time of war in our military leaders ... determined that they should have the power to do just this. There was evidence of disloyalty on the part of some, the military authorities considered that the need for action was great, and time was short. 
by Solicitor General Fahy, ${ }^{85}$ there was no possibility of anything being urged that wasn't true. And so the argument in support was made. It was made with recognition of the difficulty and importance of the case. That was also true of the companion case involving the effort of the War Relocation Authority ${ }^{86}$ to control the departure of JapaneseAmericans from relocation centers, which we lost and were delighted to lose. ${ }^{87}$ That case was lost not on constitutional grounds but on the interpretation of the executive orders involved. In effect, the Court held what we in the Division had been telling Abe Fortas ${ }^{88}$ in the Department of Interior all along - that they didn't have the authority they claimed to have. You understand that this was an authority that they claimed to be in the interest and welfare of the persons in the relocation centers-that they should not be permitted to do "imprudent" things like going to Chicago to live.

Id. at 223-24. Nowhere in the majority or concurring opinions was independent support derived from the Commanding General's report.

Justices Roberts, Murphey, and Jackson dissented in separate opinions which pointedly indicated that the majority had referred to no reliable evidence which could form the basis for any assertion that the evacuation orders had a reasonable basis in necessity. See Korematsu, 323 U.S. at 225-48. Justice Jackson declared that "[ $t]$ here is sharp controversy as to the credibility of the DeWitt report. So the Court, having no real evidence before it, has no choice but to accept General DeWitt's own unsworn, selfserving statement, untested by any cross-examination, that what he did was reasonable." Id. at 245 (Jackson, J., dissenting).

For general background on the controversy, see Korematsu, 584 F. Supp. I406, 1409-10; Commission on Wartime Relocation and Internment of Civilians, Personal Justice Denied (1982).

85. Charles E. Fahy (1892-1979): Fahy served as the first General Counsel to the National Labor Relations Board, as a legal advisor to the Department of State, as Solicitor General between 1941 and 1945, and as a member of the American Delegation to the San Francisco Conference and later to the United Nations. During the Truman Administration, he chaired the President's committee to eliminate discrimination from the armed forces. He became a Judge on the U.S. Court of Appeals for the District of Columbia in 1949 and sat until his death. See Charles Fahy, Wash. Post, Sept. 19, 1979, at A20; Unique Judge, Crowded Town: Whispering Charlie, N.Y. Times, Sept. 20, 1979, at A22.

86. The War Relocation Authority was created by President Roosevelt in Exec. Order No. 9102, 7 Fed. Reg. 2165 (1942). It was organized to hold joint responsibility with the War Department for the program of mass evacuation of Japanese-Americans from their West Coast homes. The Authority's director was Milton S. Eisenhower, brother of General Dwight D. Eisenhower. The Authority's legal staff were responsible for drafting internment regulations and dealt with legal affairs concerning camp residents. WRA attorneys volunteered at the start of the Authority's test cases to conduct the legal research on which the Justice Department's briefs and arguments would be based. See Irons, supra note 84, at 69-70, 121-22.

87. See Ex Parte Endo, 323 U.S. 283 (1944).

88. Abe Fortas (1910-1982): Fortas served as Director of the Division of Power in the Department of the Interior from 1941-1942, eventually rising to Under Secretary. Fortas later founded a prominent Washington law firm, served as a subcabinet official and a presidential advisor, and sat as a Justice of the Supreme Court. See Laura Kalman, Abe Fortas: A Biography (1990). 
That raises a question about you as a government attorney and your responsibilities to your immediate client, the War Department. It sounds as though you had reservations about making some of the arguments that the War Department urged on you.

Oh, we explicitly rejected arguments that they asked us to make. We didn't make any argument that we had qualms about. We did refuse to make arguments. We took the position that it was not for nothing that the statutes of the United States vested the control of Supreme Court litigation, as well as other litigation, in the Department of Justice and not in the War Department. We had constant acrimonious discussions, even with $\mathrm{McCloy},{ }^{89}$ who was hardly a dictatorial military type, and in whose bailiwick this fell.

Notwithstanding the fact that you refused to make some of these arguments, the Korematsu case is virtually the only case in which the Supreme Court has upheld a statute explicitly based on racial grounds, and it is viewed by many as being a black mark in the history of constitutional jurisprudence. ${ }^{90}$ Looking back on it, do you have any regrets about having made some of the arguments that were made?

No, I think what we provided was what the Court was entitled to and what the government was entitled to. After all, the responsible person in Korematsu was the President of the United States. And what's more, the orders that he made, as you know, were made over the opposition of the Attorney General.

So the question you have to ask is, was this a resiguing issue? And if it was, the time to resigu was when the order was made, not at the litigation stage. ${ }^{91}$

89. John Jay McCloy (1895-1989): McCloy served as Assistant Secretary of War from April, 1941 through November, 1945. A graduate of Harvard Law School, McCloy was High Commissioner for Germany at the end of the Second World War. He then became senior partner in the New York law firm of Milbank, Tweed, Hadley \& McCloy. McCloy also held positions as Chairman of the Chase Manhattan Bank, head of the Council on Foreign Relations, and President of the World Bank. See Kai Bird, The Chairman: John J. McCloy, the Making of the American Establishment (1992); Walter Isaacson \&: Evan Thomas, The Wise Men: Six Friends and the World They Made (1986).

90. In 1980 a Commission on Wartime Relocation and Internment of Civilians (CWRIC) was established by Congress to investigate the internment program. The CWRIC report, issued in 1982, found there was no basis for the War Department's justification of military necessity, and that American Government officials knew this when the program was instituted and when the Hirabayashi case was being briefed and litigated. See Hohri v. United States, 782 F.2d 227, 232 \& n.6, 252 (D.C. Cir. 1986); see also Monroe Leigh, Judicial Decisions, 80 Am. J. Int'l L. 645, 649 (1986) (discussing Hohri and CWRIC report).

91. The ABA Canons of Professional Ethics, adopted in 1908, in effect at the time of Wechsler's supervision of the briefs defending Japanese internment policies, provided for permissive withdrawal from legal representation:

The right of an attorney or counsel to withdraw from employment, once assumed, arises only from good cause .... The lawyer should not throw up the unfinished task to the detriment of his client except for reasons of honor or 


\section{The Attorney General opposed the executive order from the outset?}

Yes. That's fully written up in Biddle's book. ${ }^{92} \mathrm{He}$ opposed it vigorously, and he blamed himself for not opposing it vigorously enough. He was new to the Attorney Generalship, and of course Stimson ${ }^{\mathbf{9 3}}$ was held in such awe by the entire Cabinet, and he ardently supported the program, as did McCloy. If Stimson hadn't supported it, it never would have gotten to the White House. No, he carries four-square responsibility for it, as does McCloy. If you look at Stimson's biography, you won't find any regrets expressed, either. ${ }^{94}$ The only regrets you'll find are in Biddle's.

\section{Did you have similar qualms about the extension of martial law in Hawaii?}

self-respect. If the client insists upon an unjust or immoral course in the conduct of his case, or if he persists over the attorney's remonstrance in presenting frivolous defenses, ... the lawyer may be warranted in withdrawing on due notice to the client ....

ABA Canons of Professional Ethics Canon 44 (1978). Current ABA Model Rule of Professional Conduct I.2(b) states that "[a] lawyer's representation of a client . . . does not constitute an endorsement of the client's political, economic, social or moral views or activities," but Model Rule I.16(b)(3) permits the withdrawal from representation of a client when a client "insists upon pursuing an objective that the lawyer considers repugnant or imprndent." Model Rules of Professional Conduct Rules 1.2(b), 1.16(b)(3) (1992). The current rules, of course, were not applicable to Wechsler at the time nor is it clear that the existing canons would have necessarily constrained an attoruey working for the U.S. government.

The view that decisionmakers within government agencies operate under ethical constraints which vary according to the role played by the decisionmakers has been advanced by political and social theorists including Woodrow Wilson and Max Weber. For an application of this general perspective to the ethical responsibilities of government attorneys, see Geoffrey P. Miller, Essay, Government Lawyers' Ethics in a System of Checks and Balances, 54 U. Chi. L. Rev. 1293 (1987). Advocates in favor of acting upon personal morality have argued that formal legalism compels subordinates in bureaucratic systems to treat moral dilemmas "in a way that ignores or overrides deeply held beliefs that are at odds with the political values [they are] expected to employ." John P. Burke, Bureaucratic Responsibility I0, 164 (1986); see also Monroe H. Freedman, Understanding Lawyers' Ethics 44-52 (1991) (criticism of personal morality perspective). Regarding resignations for reasons of conscience, see generally Robert $M$. Cover, Justice Accused: Antislavery and the Judicial Process I49-58 (I975) (opposition to slavery); Michael Walzer, Political Action: The Problem of Dirty Hands, 2 Phil. \& Pub. Aff. I60, 164-72 (1973) (political campaigning); Edward Weisband \& Thomas M. Franck, Resignation in Protest: Political and Ethical Choices Between Loyalty to Team and Loyalty to Conscience in American Public Life (1975) (opposition to government policy).

92. See Francis Biddle, In Brief Authority 212-16, 218-19 (I962).

93. Henry L. Stimson (1867-1950): Stimson served as Secretary of War during the Administrations of Presidents William Howard Taft and Franklin Roosevelt. See Godfrey Hodgson, The Colonel: The Life and Wars of Henry Stimson, 1867-1950, at 248-6I (1990).

94. Stimson argued in 1948 that "Japanese raids on the west coast seemed not only possible but probable in the first months of the war, and it was quite impossible to be sure that the raiders would not receive important help from individuals of Japanese origin." Henry L. Stimson \& McGeorge Bundy, On Active Service in Peace and War 72-73, 214-15, 314-61, 406 (1948). 
You mentioned that you were pleased, perhaps, that the Court had held against you in that case.

Yes, but again, I had no qualms about presenting the arguments. There was, I thought, a solid question of whether the statutes relevant to the authority to declare martial law there extended beyond the emergency, and there was a substantial question whether there was a constitutional dimension to it.

But understand that martial law had been declared. These people who were involved in the case had been tried by a military court and sentenced to prison. This was a habeas corpus proceeding. I mean, we couldn't order the Department of the Army to release them. Only a court could do that.

So the question then is, should the Department of Justice have confessed error? If we had, the Court would have reproved us, because what the Court wanted was argument. The Court didn't want the Department of Justice deciding these cases. It wanted, once they were in court, to exercise its jurisdiction.

Indeed, in my year in the SG's office, there came a point where Chief Justice Stone told Biddle that the Court would like more argument. That is, he took the position that we in the SG's office were confessing error too generously.

Now, the interesting question about all this that you should ask yourself is really the resigning question. When is the right thing to do to get out? Or to put it another way, when should you feel compromised by participating at all in a proceeding that may result in sustaining something that you would feel regret about having sustained? I made a speech about that once, and it was printed in a book called Integrity and Compromise. ${ }^{95}$ In the course of the speech, I referred to the Japanese evacuation problem and I said this: ${ }^{96}$

In the Department of Justice it is a fair statement of the case to say that the view held was that no special security measures were required, that the danger, if there was a danger, could be met by identifying individuals whom there was cause to fear and dealing with them in accordance with law; if they were aliens, by internment; if they were citizens, by arrest in the event they were guilty of violations.

$\mathrm{Mr}$. Biddle presented this position very forcefully to the President of the United States. The contrary position was pressed, however, and pressed very vigorously on the War Department. A great lawyer and a great man was Secretary of War, Henry Stimson. ... In the end it became clear that Secretary of War Stimson was persuaded that strong action was

95. See Herbert Wechsler, Some Issues for the Lawyer, in Integrity and Compromise: Problems of Public and Private Conscience 117 (R.M. Maclver ed., 1957).

96. The text that follows is an extensive quotation from Professor Wechsler's earlier speech, which he read verbatim during the interview. 
needed, and this view was presented to the President by Secretary Stimson.

The question I put to you is, what should have been Mr. Biddle's course at this point, as Attorney General, as the custodian of law in the national administration, the traditional role of any Attorney General? Should he have advised the President of the United States that to undertake the type of action that was called for, namely, really the expulsion of the entire Japanese population, was unconstitutional? Should he have taken that course?

He believed that it was undesirable to take this measure, but that if it were taken the United States Supreme Court would sustain its validity as an extreme war measure.

What he did was to advise the President that the Department of Justice would not take such an action, that if any such action were to be taken, it must be taken by the War Department and on the responsibility of the military, but that if the military deemed the action to be necessary for the preservation of the country, or, as he said, a proper precaution for defense of the country, that it would probably be sustained by the United States Supreme Court, and on this record and against this background the President of the United States did issue Executive Orders authorizing the Commanding Generals of the various Commands, with the approval of the Secretary of War, to issue the [exclusion orders].

Following the issuance of that order, Congress enacted a statute declaring it to be a civil crime, misdemeanor, for anyone to refuse to obey such an order, and so it was that the entire Japanese population of the West Coast was removed. ${ }^{97}$

Today, I would not write "Japanese population." The entire population of persons of Japanese ancestry on the West Coast was removed, and large numbers of the group found themselves in what in any fair estimate should be called concentration camps, although they were given a more appealing name. They were called "relocation centers." I went on to say:

$[\mathrm{A}]$ nd there they stayed for some two years, until the order was finally rescinded.

One of the members of this population, a man by the name of Korematsu, refused to obey the order, and he stood prosecution. The purpose of standing prosecution was to test the constitutionality of the entire program.

It fell to me in my duties as Assistant Attorney General, to superintend the preparation of a brief in support of the constitutionality of the evacuation program, though I think no one could have felt more distressed about its existence, other than those personally affected by it, than I.

Should I have declined to assume the preparation of a 
brief in support of the constitutionality of what the President of the United States had ordered on the recommendation of his distinguished Secretary of War? I might have done that. In fact, however, I did not. I did superintend the preparation of that brief. It presented the strongest arguments that I felt could be made in support of the validity of the action taken by the President and, in fact, as you know, the Supreme Court sustained its validity.

I was in court the day of that decision, and though I had a share in winning the case, it was not for me a happy day. You may ask why I did it. Of course, I could have resigned. Of course, Mr. Biddle could have resigned.

I did it because it seemed to me that the separation of function in society justified and, indeed, required the course that I pursued; that is to say that it was not my responsibility to order or not to order the Japanese evacuation, neither was it, in fact, Mr. Biddle's responsibility to do so. It was the responsibility of the President of the United States, who had been elected by the people of the United States. Neither was it either Mr. Biddle's responsibility or my responsibility to determine whether the evacuation was constitutional or not constitutional. That was the responsibility, in this context at least, of the Supreme Court of the United States, composed of nine men, nominated by a President and approved by a Senate, to hold that office.

I suggest to you, in short, that one of the ways in which a rich society avoids what might otherwise prove to be insoluble dilemmas of choice is to recoguize a separation of functions, a distribution of responsibilities, with respect to problems of that kind, and this is particularly recurrent in the legal profession. ${ }^{98}$

Would you care to add something to those words?

I would stand by those statements today. I might be a little readier to resign at my present age than I was at the age of . . . thirty-four, I think I was then. That might also be a function of fatigue.

Are you saying that the issue was either to resign or to carry out the task?

Yes.

And there was no other middle ground?

What middle ground could there have been?

Was it ever a serious option for you? I mean, did you consider the resignation option seriously?

No, I never considered it seriously. That was not my view.

So you posed this problem many years after it had, in fact, occurred. This speech was not written in the throes of struggling with your immediate concerns?

No, no. This was ten years later at least. 
And you suggest that in a less specialized society, the resigning issue might arise more frequently and decisions to resign might be made more often?

You see, we did not remove the Japanese from the West Coast. If the distribution of responsibility had been such that the President had said to the Attorney General, "You issue the Executive Order"-1 mean, he couldn't have. He didn't have the authority, but assume that it had been set up so that he might have. Then you might have gotten a resignation. But when it's somebody else that takes the responsibility and does it, and you are involved in it after the fact, the question is whether you're going to defend it as within the law. That's a very different kind of problem.

Is it similar to what happened when Elliot Richardson was ordered to fire Archibald Cox during the Watergate events, despite Justice Department regulations preventing Richardson from firing him?

That's right. If President Nixon had fired Archie Cox, and the issue had been drawn into litigation in the Court of Claims, for example, Elliot might very well have said, "Well, I'll make the argument in support of the President's authority to fire him."99

But Richardson had no choice but to resign when he was ordered to fire Cox? Yes, I think the President might have wanted that outcome.

\section{Preventing Undeserved Punishment at Nuremberg}

At times during the Second World War, the Allies condemned Nazi war crimes and atrocities in general terms. In June, 1942, the Inter-Allied Conference on Punishment of War Crimes declared that Axis war crimes would be punished through recognized channels of justice. A War Crimes Commission was established under United Nations auspices in 1943. That year the Allies agreed, in the Moscow Declaration, that the German war criminals would be tried and punished by joint decision of the Allied powers.

For most of the war, however, the Allies were reluctant to discuss in specific terms how they would punish captured Nazi leaders. Only in the summer of 1944 did the British and American governments definitively reject proposals such as those for the summary execution of Nazi war criminals, and specify a framework for "war crimes" trials to follow the end of hostilities.

As head of the War Division of the Justice Department, Wechsler had jurisdiction over a "miscellaneous" category of assignments that covered war-related problems not within the routine assignments of other divisions. This was, he said,

99. The Justice Department Guidelines, the product of negotiations between the Senate Judiciary Committee and Attorney General Richardson, provided that the special prosecutor could be fired by the Attorney General only for "extraordinary improprieties." See Congressional Q., Watergate: Chronology of a Crisis 370 (1975). Richardson, further, had given special assurances to Cox about the independence that the special prosecutor would exercise. See generally Sam J. Ervin, Jr., The Whole Truth: The Watergate Conspiracy 228-45 (1980); Stanley I. Kutler, The Wars of Watergate: The Last Crisis of Richard Nixon 329-407 (1990); Douglas Muzzio, Watergate Games: Strategies, Choices, Outcomes 59-114 (1982). 


\section{"the way the Nuremberg problem fell into my lap,"100 in September, 1944.}

One day I received from Attorney General Biddle a long memorandum that had been prepared in the War Department by somebody I didn't know, by the name of Murray Bernays. ${ }^{101}$ And what the Attorney General asked me to do was examine it and come and discuss it with him. So I did, and that was my introduction to the laws of war. We all, of course, had learned something minimal about the subject of the laws of war as a result of the so-called Saboteur Case, ${ }^{102}$ the German agents who were landed on the Florida coast by submarine and were then tried by a military commission in the Department of Justice Building in the early days of the war.

The question of military jurisdiction to try those men was raised in the Supreme Court and decided in the famous Quirin case, ${ }^{103}$ sustaining the appropriateness of a military trial and the jurisdiction of the military commission to try, under the laws of war, enemy combatants who penetrated within the lines, as the formula goes, out of uniformthe international recognition of the legitimacy of trying and executing spies, recognized from time immemorial by customary international law, and no doubt by the Hagne Convention. ${ }^{104}$ The opinion by Stone in the Quirin case gave us all a more solid sense that there was in existence a genuine body of law of an international character that belligerents were obliged to respect, subject to valid retribution if they failed to do so. In all the years that I had up to then been studying and teaching law, I don't believe I ever read a thing about the laws of war. Stone's opinion is a very informative document for the uninitiated.

Now the Bernays Memorandum ${ }^{105}$ had for its main thrust to go

100. Oral History, supra note 1 , at 191 .

101. Colonel Murray C. Bernays (1894-1970): A New York lawyer, Bernays led the Special Projects Branch within the War Department. The Special Projects Branch spent considerable effort determining ways to prevent German reprisals against Allied prisoners-of-war. Bernays, like most of his co-workers, had a perspective on German atrocities based mainly on the Nazi persecution of Jews and others committed in the later 1930s. Concerned that harsh pronouncements about the fate of Nazis who fell into Allied hands would jeopardize soldiers who were held prisoner, Bernays' "primary assignment was not to develop a plan to stop atrocities, but to formulate a system that would defer action until after the war was over, thus sparing American personnel from reprisal," and to develop a clear and relatively simple formula that would give the War Department an effective answer to the harshly retributive plan of Henry Morgenthau, Secretary of the Treasury. See Bradley F. Smith, Reaching Judgment at Nuremberg 22-27 (1977) [hereinafter Reaching Judgment].

102. Ex Parte Quirin, 317 U.S. 1 (1942).

103. See id.

104. See Laws and Customs of War on Land (Hague II), July 29, 1899, ch. Il, art. XXX, reprinted in 1 The Law of War: A Documentary History 230 (Leon Friedman ed., 1972) [hereinafter The Law of War].

105. Colonel Bernays drafted a plan for the trial of Nazi war criminals. The Memorandum criticized Treasury Secretary Morgenthau's call for military execution of war criminals because it did not comport with American standards of justice. Bernays called for the creation of an international tribunal that would judge individual 
beyond the legitimacy of trial and judgment and punishment for what might be called conventional war crimes-killing prisoners without trial being the most obvious example of a murder that the existence of war did not provide a legal justification for. Actions against civilian populations in captured territory would be a second illustration.

1t would have been possible to think about post-war reprisal and punishment simply in those terms. That's pretty much the way it was thought about at the end of the First World War.

But the whole thrust of the Bernays Memorandum was not to exclude thinking about it in those terms, but to go beyond it and also think about it in what seemed to us to be novel terms. Particularly novel was the proposal to charge that the initiation of the conflict was a violation of the laws of war or of international law justifying a punitive reprisal. And that's where we started with the Bernays Memorandum.

The original Memorandum proposed to deal with the whole matter as a charge of conspiracy, and it was said that this approach had been inspired by Secretary Stimson, who had been United States Attorney here in New York in the Southern District at a time when the government prosecuted some Sherman Act conspiracies-sugar cases. ${ }^{106}$ That recollection somehow instilled in Stimson's memory a kind of warm, happy recollection of the law of conspiracy. Of course, the Sherman Act is so drafted that one of the subjects that it condemns is a conspiracy in restraint of interstate commerce. ${ }^{107}$

It did not quite occur to Stimson that maybe international law didn't similarly recognize the criminality of conspiracies. That was the first problem engendered by the Bernays Memorandum, and one that I knew something about from my work in criminal law. The thing that I knew was that Anglo-American law, both common law and statutory law, defined a general offense of criminal conspiracy, meaning by that a combination to engage in criminal conduct, and in many of the common law formulations even went beyond that to include a combination

defendants as well as Nazi institutions. The Memorandum effectively put the Nazi regime on trial, extending the concept of Nazi criminality to inculpate Germany itself as well as Germany's actions in occupied Europe. Bernays' plan would have extended the liability of the regime back in time to the beginning of the Nazi government. In part because the magnitude of the atrocities at Auschwitz and other death camps was unclear to him at the time, however, Bernays chose to make the relatively lesser prewar Nazi atrocities the basis for a conspiracy charge. His operating conception was of a great criminal plot executed by a group of criminal conspirators. See Ann Tusa \& John Tusa, The Nuremberg Trial 54-57 (1990); Telford Taylor, The Anatomy of the Nuremberg Trials: A Personal Memoir 46-55 (1992).

106. See Hodgson, supra note 93, at 64-67; Stimson \& Bundy, supra note 94, at 8-9. Stimson obtained and defended on appeal convictions under the Sherman Act against sugar manufacturers for conspiring to commit fraud with respect to the inaccurate weighing and labeling of sugar. See Heike v. United States, 227 U.S. 131 (1913).

107. See 15 U.S.C. \& 1 (Supp. III 1991). 
to engage in oppressive or immoral, but noncriminal, conduct, though only as a misdemeanor.

I also knew tbat it was most unusual in the civil law countriesFrance, Germany, and Italy, for example-to recognize a broad offense of conspiracy. ${ }^{108}$ There were certain combinations that were criminal under those codes, but it was not an offense across the board. And then, looking further into it, it became evident to me that Bernays himself was confused between conspiracy as a crime and conspiracy as a mode of complicity in substantive offenses, committed by one of the conspirators. All civilized systems recognize conspiracy-or at least agreement, encouragement-as a mode of criminal participation in the commission of substantive offenses.

Since we were confronting a situation in which it was considered that twenty million people at least had been killed, many of them unlawfully, nothing seemed more ridiculous to me than to have our sense for what justly demanded punishment be the plan-criminal, whether or not it had ever been carried out, rather than what had been carried out-utilizing conventional doctrines to determine who was responsible for what had been carried out-which would have introduced, to a degree at least, the idea of conspiracy as a mode of complicity.

My first challenge to the Bernays memo was on that point, and I challenged both its legal acceptability and its wisdom, with the emphasis perhaps on its wisdom, given the situation we were dealing with. ${ }^{109}$ Biddle agreed with me at once. And one of the key points on which the revised Bernays plan differed from the original was that it shifted from the notion tbat we were going to prosecute an inchoate offense, to use the technical term, rather than a completed offense. And there was notbing novel about that, you see. I mean, just as the so-called saboteurs had been prosecuted for a group offense, passing through the lines in a group, a belligerent group, with belligerent intent, without the insignia to identify them as belligerents. The Department of Justice was thoroughly successful in reshaping the conception that was written up in the document that was to be submitted for approval as a basis for formulating an American proposal.

The other equally important point, of course, was the submission that it was appropriate to charge, not only the manner of belligerency, but the initiation of the belligerency as a crime under international law. ${ }^{110}$ Our original position was to resist that, in the view that they

108. See Stanislaw Pomorski, Conspiracy and Criminal Organizations, in The Nuremberg Trial and International Law 213, 218 (George Ginsburgs \& V.N. Kudriavtsev eds., 1990).

109. Memorandum to Attorney General (Francis Biddle) from the Assistant Attorney General (Herbert Wechsler) (Dec. 29, 1944), published in Bradley F. Smith, The American Road to Nuremberg: The Documentary Record 1944-45, at 84-90 (1982) [hereinafter American Road].

110. The international conventions arrived at in the Hague between 1891 and 1907 
had so much about unlawful belligerency, there's no need to make any new law. Stimson, however, was greatly attracted to this because of the position that he'd taken back earlier, when he was Secretary of State: the Kellogg-Briand Pact ${ }^{111}$ and the so-called renunciation of war as an instrument of national policy. It was very congenial to him, because of his identification with that development, to see it argued that the development had been so successful that it had become customary international law.

The Kellogg-Briand Pact, however, said nothing about sanctions. And even the League of Nations had approached the problem in terms of the justifiability of preventive measures rather than the notion that this was the basis for criminalizing individual conduct. ${ }^{112} \mathrm{We}$ presented that objection, but our position recognized that, given the legitimacy of the prosecution on other counts, adding the count, even though it had a weaker basis, was less objectionable than if that were the sole basis for proceeding against the defendant. Just as in domestic criminal law, if a conviction rests on two counts and either count is broad enough to support the sentence, you won't get a reversal even though the opinion may say that the second count was no good.

The rest of the story really was a long process of negotiating out those details on the one hand, and on the other hand exploring with the rest of the government the question whether the British position, which had been formulated as hostility to any trials-in fact favoring an execution list to be carried out just on identification of the individuals-whether an impulse to resist that approach was sound or not. It was tied up with the contemporary development of the so-called Morgenthau or Treasury Plan, ${ }^{13}$ a sort of scorched earth approach to

provided an operating principle for the creation of an agreement outlawing aggressive war. Although the Hague Convention itself did not create a trial system for those who broke its rules, the signatory powers regnlarly punished violators of the Convention in their own domestic courts. The Tribunal judges argued further that such agreements as the Locarno Pact (1925) and the Kellogg-Brand Pact (1928), see note 111, infra, had established the illegality of aggressive war. See Reaching Judgment, supra note 101, at 155-56.

111. The Kellogg-Briand Pact, also known as the Pact of Paris, condemned war and called for the peaceful resolution of international disagreements. It was signed in 1928 by 63 countries. A substantial body of opinion at that time and subsequently considered the Pact unenforceable, naive, and ill-conceived; another line of thought, shared by Secretary of State Henry Stimson, considered the Pact not merely idealistic, but an expression of its signatories' legal commitment. See generally Robert H. Ferrell, Peace in Their Time: The Origins of the Kellogg-Briand Pact (1952) (discussing debate and legislative history).

112. The League of Nations approach to disciplining a country that initiated belligerency is discussed in Ferrell, supra note 111, at 120-24.

113. The Morgenthau Plan, presented to the President by Treasury Secretary Henry Morgenthau in Augnst 1.944, called for a drastic retaliation against Germany that would render that nation incapable of replicating its Nazi-era atrocities. The Plan called for a complete and lasting demilitarization of the German nation, in light of Germany's defiance of the Versailles Treaty. The Plan also mandated the destruction of the Nazi 
post-bellum Germany, which for some carried with it the notion that individuals, as well as the earth, should be scorched without much ado. It doesn't speak well for the memory of Morgenthau, I don't believe.

Do you remember your own personal enthusiasm for the prospect of creating legal instruments that might control aggression?

I'll tell you, my thinking went through something of a development on that point. Initially, I think I had the sense that it was a mistake to go at this matter in any but the most conventional terms, because you were dealing with people whose guilt was so enormous that you shouldn't give them an issue. So I think my initial impulse was to combine a legal conservatism and a sense of what was prudent, and to throw my weight, to the extent that I had any, towards keeping the charges within the most conventional terms.

I was not too sympathetic, I may say, with one aspect of the juice behind broadening the business. That was the concern to be able to deal with atrocities inflicted upon persons of German nationality, which would have been principally killing Jews-though not exclusively, of course. I'm sure that was a strong motivation for Bernays, to attempt to find a theory that would provide a basis for that type of inclusion in the charges. It seemed to him to be Hamlet without the Prince, to prosecute the Nazi leaders and to pay no attention to the treatment of Jews.

Well that wouldn't have been true, because the Nazis didn't just go after the German Jews, and to the extent tbat they were responsible for the extermination of alien Jewish populations, which was, after all, the largest number of Jews who were killed, the laws of war had complete and total application. ${ }^{14}$ So it seemed to me that this was a right big fuss to try to include the German Jews within the reach of the grievance.

And on the whole, Biddle agreed with me on that subject, and we had an effect, because if you look at the Agreement of London, ${ }^{15}$ the so-called Nuremberg Charter, you'll find it is only in connection with other things within the Tribunal's jurisdiction that domestic atrocities are embraced within the offenses that are to be prosecuted.

Those were the main issues that we played with during all that time, and my involvement in it was not only in the bureaucratic exchange of documents, but also conferences in Washington where I usually represented the Attorney General, including the White House

Party, the removal and internment of Nazi officials, and the elimination of German industry with a concomitant pastoralization of the country. Major war criminals would be identified and shot. Morgenthau's account can be found in J. Blum, From the Morgenthau Diaries: Years of War 1941-1945, at 332-33 (1967).

114. Estimates by contemporaries were that more than three-quarters of the Jews killed during the Holocaust were from Poland and lands conquered from the Soviet Union. See, e.g., Michael R. Marrus, The Holocaust in History 58 (1987).

115. Prosecution and Punishment of Major War Criminals of European Axis, August 8, 1945, in 1 The Law of War, supra note 104, at 883-93. 
conferences that Judge Rosenman ${ }^{116}$ began to develop, since the President asked him to take charge of the coordination of these planning efforts. And later conferences with the British on the subject, in the effort to reach agreement. ${ }^{117}$

The main contact that I had with the international negotiations was a conference in San Francisco, held for convenience at the time of the first United Nations conference. ${ }^{118}$ I'll never forget that first session at the Mark Hopkins Hotel. It was called for early afternoon. The Secretary of State's suite was the biggest one in the hotel, and it had a big terrace, and Ammi Cutter 119 and I were staying, I think, at the Union League Club, just across from the Mark Hopkins. The meeting convened, with Secretary Stettinius ${ }^{120}$ presiding, and Judge Rosenman; Molotov $^{121}$ heading the Russian delegation; Anthony Eden ${ }^{122}$ and I think Alexander Cadogan ${ }^{123}$ for the English; and either it was Professor

116. Justice Samuel I. Rosenman (1896-1973): First appointed and then elected to New York's Supreme Court in 1933, Rosenman thereafter became President Roosevelt's most prominent speech writer and special legal adviser. See Samuel I. Rosenman, 77; Coined New Deal for Roosevelt, N.Y. Times, June 25, 1973, at 1.

117. See American Road, supra note 109, at 136-42.

118. British, Russian and French delegates attended the San Francisco Conference. It resulted in a call for the establishment of an international military tribunal to prosecute war criminals who would then not be tried in occupied countries where they were suspected of particular crimes. See id. at 139-41, 193-203.

119. Colonel R. Ammi Cutter (b. 1902): Cutter worked as Assistant Attorney General of Massachusetts and as a partner in a Boston firm before becoming an officer on the Army General Staff and assistant executive officer to Secretary of War John J. McCloy. Cutter later became a Justice of the Massachusetts Supreme Judicial Court. See id. at 50-56, 139-41; see also Cutter, Richard Ammi, Who's Who in Government (1972-1973 ed.).

120. Edward Reilly Stettinius, Jr. (1900-1949): Stettinius served as an executive of General Motors (1926-1934), Chairman of the Board of U.S. Steel Corporation (1938-1940), and U.S. Secretary of State (1944-1945). He resigned to serve as U.S. Representative to the United Nations (1945-1946). See Stettinius, 49, Dies of Heart Attack, N.Y. Times, Nov. 1, 1949, at 1.

121. Vyacheslav Mikhailovich Molotov (1890-1986): Molotov served as First Deputy Prime Minister of the U.S.S.R. beginning in 1941, and previously held the post of foreign minister. The negotiator of the Russo-German nonaggression pact of 1939, Molotov was a prominent Russian spokesman during and after the War. See Raymond H. Anderson, Vyacheslav M. Molotov Is Dead; Close Associate of Stalin's Was 96, N.Y. Times, Nov. 11, 1986, at Al.

122. Sir (Robert) Anthony Eden (1897-1977): Eden was British Foreign Secretary (1935-1938 and 1951-1955) and Prime Minister (1955-1956). He resigned as Foreign Secretary in protest of Prime Minister Neville Chamberlain's "appeasement" of the Axis powers. See David Carlton, Anthony Eden, A Biography 294-367, 368, 464 (1981).

123. Sir Alexander Cadogan (1884-1968): Cadogan was senior advisor to British Prime Minister Winston Churchill during World War II, serving as under-Secretary of State in the Foreign Office. He accompanied Churchill to the World War 11 summit conferences and authored the first draft of the Atlantic Charter when Churchill and President Roosevelt conferred in Newfoundland. See generally The Diaries of Sir Alexander Cadogan 1938-1945 (David Dilks ed., 1971). 
Basdevant ${ }^{124}$ or he and somebody else, representing the French, as the principal participants. We staff people were sort of in the back. The principal representatives were seated around, with their chairs in a little circle, facing each other, talking easily.

Rosenman made a very careful, short speech, indicating the position that we favored ${ }^{125}$ - that we favored a trial, rather than executive disposition of the accused; that we had given great thought to what the charges should be and how they should be tried, and we favored an international tribunal, and so on. I remember Eden saying that as everybody knew, Her Majesty's government had been opposed to the concept of a trial. But having put its position as powerfully as it could and not having persuaded its great allies, it was prepared to yield.

And then the discussion moved into more details, and Judge Rosenman expounded the other aspects of the plan-namely the notion that it was desirable not just to try individuals, but to provide a foundation for a kind of mass retribution against those who had participated in the main Nazi organizations that had organized and exercised violence, both within Germany and outside-thinking of the SA and the SS and the Gestapo, and the General Staff as organizations. ${ }^{126}$

The idea was that those organizations would be charged and tried as organizations, as criminal organizations. And if convicted, then those who were in subsequent proceedings proved to be members of the organization would be subject to criminal sanctions just upon proof of their membership. In this way it was envisaged that not only would the leaders be subject to just reprisals, but also the masses, whose participation had been essential for the leaders to realize their nefarious objectives.

At this time a lot of attention was being given to the idea that it would be a great mistake if the post-bellum reaction was limited to dealing with the German leaders and without extending punitive repri-

124. Jules Basdevant (1877-1968): A French jurist and author of works on history, jurisprudence and international law, Basdevant aided the Gaullist resistance during the war, and afterward advised the restored French government. See Jules Basdevant, Jurist, 90, Is Dead, N.Y. Times, Jan. 7, 1968, at 85.

125. See Rosenman Tells 3 Powers of U.S. Plans to Try War Criminals "Without Delay," N.Y. Times, May 11, 1945, at 13.

126. The SA (Sturmabteilung, or storm troops) was the brown-shirted private army of the Nazi Party. The black-shirted SS (Schutzstaffeln or security echelon) originally composed Hitler's bodyguard, and had its own police, intelligence, and military units. The Gestapo was the Secret State Police, whose handpicked units, along with the SS, participated in the perpetration of the most heinous crimes. The General Staff was the term applied to a body of experts formed to advise the German field commanders, somewhat along the lines of a war college. The Staff, which had included approximately 130 officers during its existence, was indicted at American insistence. See Taylor, supra note 105, at 41-55. For treatment of the complex structure of the Nazi security and military apparatus, see 1 Raul Hilberg, The Destruction of the European Jews 53-62 (rev. ed. 1985); Eugen Kogon, The Theory and Practice of Hell: The German Concentration Camps and the System Behind Them 17-29 (Heinz Norden trans., 1950). 
sal to those who had done the leaders' dirty work throughout the period envisaged by the charges. So we were not hostile to the idea that the relevant concept of guilt might very well extend well beyond those who were in the top echelons of party and state.

The shocking thing about this proposal obviously was its due process aspects. ${ }^{127}$ The criminalization of the rank and file was to take place in a proceeding in which the crucial issue, namely, what was the character of the organization, would be determined in a proceeding in which they weren't parties. To be sure, it was envisaged that the organization would be represented, but this seemed to us to press too far the idea of representation by representative parties, which in our domestic law had never been accepted in criminal proceedings, however much it played a part in civil procedure. To extend it on this mass basis seemed to us to put in jeopardy the justice of the whole approach.

I guess that it is true that in our resistance to that aspect of Bernays' proposal, we were least effective. I don't recall that we got anything in the document that really was responsive to the problem, and if we did, it didn't amount to much.

Do you think that the massacre at Malmedy ${ }^{128}$ had something to do with that?

I know that Bradley Smith makes a point of the Malmedy episode, and he has the timing chronology correct. ${ }^{129}$ All that I can say is that Smith's perspective is plausible to me. I'd be surprised, however, if he doesn't dramatize the thing somewhat in suggesting that it produced a dramatic change in Biddle's attitude. Surely, Malmedy was cleverly exploited by Bernays and his supporters. You know: "Look, this terrible thing happened, but if we don't know who the individuals were who did this, are we going to let the SS go scot free?" Well, the answer should have been yes. If we don't know who committed a crime, then we don't just up and convict or punish somebody else.

My 'recollection is that we didn't prevail at the drafting stage on

127. Regarding a German view of the due process objections, see Werner Maser, Nuremberg: A Nation on Trial 259-87 (Richard Barry trans., 1979) [hereinafter Nation on Trial]; Herbert Kraus, The Nuremberg Trial of the Major War Criminals: Reflections After Seventeen Years, 13 DePaul L. Rev. 233, 236-47 (1964).

128. The Massacre at Malmedy was the most egregious Nazi atrocity committed against American armed forces. In December, 1944, during the Battle of the Bulge, 115 prisoners-of-war were massacred by an SS detachment at Malmedy, Belgium. A comparatively small Nazi atrocity by wartime standards, it shook up the American government and swept away hesitations about the inclusion of all the military SS in the prosecution of criminal organizations. The New York Times reported the incident on January 1, 1945 as follows: "Allied Supreme Headquarters in an official statement today confirmed front reports that 115 helpless American soldier prisoners had been murdered in cold blood by the enemy soon after the opening of the German counteroffensive." German Tank Guns Slew 115 Captives-Americans Lined up Six Deep to Be Massacred, Supreme Headquarters Finds, N.Y. Times, Jan. 1, 1945, at 3.

129. See Reaching Judgment, supra note 101, at 33-35. 
that, and the fact that Biddle joined in signing the memorandum to the President which urged him to charge the German leaders and their organizations with participation in a "broad criminal enterprise" 130 was a good illustration of what an individual in office does when he's one of the responsible parties in working out a plan, a governmental plan, which ends up with provisions that he doesn't like, but he's unable to persuade others should not be included. As I said in the context of the Korematsu discussion, ${ }^{131}$ the bottom line on these things tends to be, is it a resigning issue? And nothing would have been more foolish, I think, than for the Attorney General to resign because the President approved a document that had in it a component that the Attorney General felt shouldn't be there. It would have been particularly ludicrous in this instance with its sequel. As you know, after Roosevelt died and Truman became President and this plan finally got approved, Biddle was appointed the American Judge to conduct the proceeding, and, of course, I went with him as a principal assistant. As Felix Frankfurter put it, I became a law clerk for the second time.

What happened was that when it came to the Nuremberg Trial, the Tribunal, under Biddle's leadership-but with the very ardent support of Judge Parker, ${ }^{132}$ the American alternate, and Judge Birkett, ${ }^{138}$ the British alternate judge-we simply took the Charter provisions ${ }^{134}$ and refined them by interpretation, so that the organization now consisted not merely of members, but of those members who voluntarily joined with knowledge, etc. We did the very kind of thing that the Supreme Court subsequently did in interpreting the Smith Act. ${ }^{185}$ It was a legiti-

130. Memorandum for the President: Subject: Trial and Punishment of Nazi War Criminals (Jan. 22, 1945), published in American Road, supra note 109, at 117-22; see also Reaching Judgment, supra note 101, at 34-35 \& n.50 (factul account of Malmedy episode and memo presented by Biddle to President); Taylor, supra note 105, at 42 (discussing attitudes about appropriate punishment of SS members).

131. See supra text accompanying notes 90-91, 98-99.

132. John Parker (1883-1958): Parker served as American alternate to Attorney General Francis Biddle in the Nuremberg Trial. He had become a federal circuit court judge in 1925. In 1930 he was nominated an Associate Justice of the Supreme Court, but missed confirmation by two votes. See John Parker Dies; Federal Judge, 72, N.Y. Times, Mar. 18, 1958, at 29.

133. Norman Birkett (1883-1962): A judge of the King's Bench Division of the High Court since 1941, Birkett was considered for appointment as Chief British judge at the Nuremberg Trial, but was passed over because the British Foreign Office wanted a Law Lord for the post. Judge Birkett was chosen as an alternate to the Tribunal instead. For further details about Lord Birkett's career, see Lord Birkett, Lawyer, ls Dead; Was Judge at Nuremberg Trials, N.Y. Times, Feb. 12, 1962, at 23; see also Hartford Montgomery Hyde, Norman Birkett: The Life of Lord Birkett of Ulverston 494-540 (discussing Lord Burkett's role in Nuremburg).

134. See Agreement for the Prosecution and Punishment of the Major War Criminals of the European Axis, Aug. 8, 1945, Charter of the International Military Tribunal, pt. II, art. 6, 59 Stat. 1544, 1547 (1945) [hereinafter London Charter].

135. The Smith Act criminalized membership in an organization advocating the overthrow of government. See Alien Registration Act of 1940, ch. 439, tit. I, § 2, 54 
mate thing to do-interpreting an Act of Congress., lt surely was a legitimate thing to do when interpreting an executive agreement, with a much more loosely drafted document.

To take the other point of view, wasn't there enough evidence to suggest that-certainly during the war-mere membership in the Nazi Party would have been criminal in some sense?

Oh, whether it might or might not is the crucial point, you see. It's the same story that we had here with the Smith Act and all the membership issues and that the Supreme Court really dealt with in the subsequent Smith Act cases, in distinguishing between active membership and passive membership, membership with knowledge of the illegal objective, with a purpose to further the illegal objective as distinguished from indifference as to whether it was furthered or not. We'd been through all this in this country. At least in anticipation. To be sure, this was before the Smith Act taught us what those prosecutions taught us. But it was after the Smith Act had been enacted. These issues had been raised on the Smith Act when it was up in Congress.

And remember, too, that the whole plan, which I worked out with Norman Birkett very largely, when we were in Nuremberg, had the Tribunal appointing commissioners to go out and conduct individual hearings, with a view to making recommendations as to the appropriate definition of the culpable class. It was really, intellectually, an enterprise very much like the problem of defining a class in a class action in the federal court these days.

How did you pick the year 1939 as the cut-off date, prior to which membership in one of those organizations would not be sufficient for prosecution?

Well, that was the date of the belligerency.

Even though there was prior evidence of crimes against humanity, including deportations and camps?

The Charter didn't deal with crimes against humanity except for that special definition. ${ }^{136}$ That really was deferring to the objections that we had raised as to what international law addressed. Of course, as

Stat. 670,671 (codified as amended at 18 U.S.C. $\$ 2385$ (1988)); see also Scales v. United States, 367 U.S. 203, 220-24 (1961) (interpreting Smith Act to require "specific intent to accomplish violent overthrow" and "active" membership in a proscribed organization); Yates v. United States, 354 U.S. 298, 303-12 (1957) (narrowing Smith Act's definition of "organize").

136. Article 6 of the London Charter defined crimes against humanity as:

murder, extermination, enslavement, deportation, and other inhumane acts committed against any civilian population, before or during the war; or persecutions on political, racial or religious grounds in execution of or in connection with any crime within the jurisdiction of the Tribunal, whether or not in violation of the domestic law of the country where perpetrated.

London Charter, supra note 134, part 11, art. 6, 59 Stat. at 1547. The Tribunal read the semicolon following "during the war" in the above-cited paragraph to deny it general jurisdiction over racial and religious persecutions committed prior to the date of the beligerency. See Taylor, supra note 105, at 441 n.*, 583. 
a result of Nuremberg and the conventions that followed it, mainly through U.N. auspices, like the Genocide Convention, ${ }^{137}$ there has been an enormous impetus to the development of the idea of crimes against humanity as a viable international concept. But if you go back to the period we're talking about, you didn't have the source material to deal with.

We have read that Roosevelt did not favor the idea of a war crimes tribunal. ${ }^{138}$ It seems that when Roosevelt died and Truman replaced him, that this made a major difference in the direction of the whole event.

I wouldn't say that. Roosevelt, as far as we know, took no personal part in all this, prior to Yalta. Ammi Cutter and I made a great effort to try to get war crimes put on the agenda at the Yalta Conference by strategically planned telegrams that we got our respective chiefs to sign and efforts with other lesser individuals who were going to be there.

But when the President came back from Yalta, ${ }^{139}$ all the indications were that with the exception of tbat crude interchange in which Stalin made some ghastly articulation that 50,000 people should be killed, which got Churchill and Roosevelt both all upset, nothing much was produced, as far as we could find out. ${ }^{140}$ That is, nothing had been done to push towards agreement, and it was not until the Potsdam Conference, ${ }^{141}$ with Truman, that the log jam on reaching international agreement on the London Charter was broken. Cutter was at Potsdam, and I was not, and I'm not privy to the details of what went on therebut after Potsdam, the deal was set. ${ }^{142}$

And then one day I was working in my office, and there was a knock on the back door to the office, not where anybody came in. This was a

137. The 1948 United Nations Convention on the Prevention and Punishment of the Crime of Genocide, Dec. 9, 1948, 78 U.N.T.S. 277, took effect in 1951. 1t criminalized the attempt to destroy a national, ethnic, racial, or religious group. See id. art. 1I1, 78 U.N.T.S. at 280; Documents on the Laws of War 157-68 (Adam Roberts \& Richard Guelff eds., 1982).

138. See Frank M. Buscher, The U.S. War Crimes Trial Program in Germany, 1946-1955, at 9-10 (1989); Tusa \& Tusa, supra note 105, at 61-66.

139. The Yalta Conference (February 4-11, 1945) was attended by President Franklin D. Roosevelt, Prime Minister Winston Churchill, and Premier Josef Stalin. Plans were concluded there for Germany's defeat, for its occupation and control, and for the collection of postwar German reparations. See American Road, supra note 109, at 152-53; Edward R. Stettinius, Jr., Roosevelt and the Russians: The Yalta Conference 229-32, 235-36, 245 (Walter Johnson ed., 1949); see also Russell D. Buhite, Decisions at Yalta: An Appraisal of Summit Diplomacy 21-37 (1986).

140. During a Tripartite Dinner Meeting in Teheran on November 29, 1943, Stalin made the flat statement that, because Hitler's fighting strength depended on "some fifty thousand officers and technicians," " "fifty thousand must be shot." Churchill replied that "he "would rather be taken out into the garden here and now and be shot [him]self than sully [his] own and [his] country's honour by such infamy."' Winston Churchill, Closing the Ring, 5 The Second World War 373-74 (1951).

141. The Potsdam Conference occurred between July 17 and August 2, 1945. See Charles L. Mee, Jr., Meeting at Potsdam at xi (1975).

142. See id. at $269-83$. 
door that led to a corridor that in turn led to the door to the Attorney General's office. So I was startled and surprised and 1 went and opened the door. Who was standing there but Francis Biddle, whom I hadn't seen for several months-since he had been "retired" by Truman and succeeded by Tom Clark. ${ }^{143}$ He sort of put his fingers to his lips and slipped in my door and said, "I have something very important to talk to you about, Herb." And he told me that the President had just offered him the post as American Judge on the International Military Tribunal. ${ }^{144}$ And that he was planning to accept and he hoped that I would go with him as his assistant.

I confess that I was a little bit worried about his doing it, because I thought it so important to keep the thing above suspicion. I wondered whether anybody who had been involved to the extent that he was in planning the prosecution and the development of the legal basis for it ought now to turn around and become a Judge. And I immediately raised this question with him, and asked him if he thought about it. "Well," he said, "of course I've thought about it. You surprise me, because 1 had thought that one of the things that really gave me a special qualification for doing this was the extent to which we'd worked on the problems, and I was aware of the problems." He said, "You know, I'm not aware of everything."

Well, I thought that perhaps he was right. It seemed to me to be less a question of what was defensible on the merits than of what the public reaction would be. I mean, it was less a matter of what was proper or improper than of what might seem to be an impropriety. ${ }^{145}$ In judicial standards and ethics, judges are supposed to avoid the seeming impropriety, as well as true impropriety.

You know, there is no canon that a legislator who has been instrumental in drafting a statute is thereafter, if he becomes a judge, precluded from participating in its interpretation. Justice Black, for example, had a lot of legislation that he'd been involved in as a Senator come before him, and 1 never knew him to disqualify himself on that ground, rather than to consider that, as Biddle had said to me, that it really was a qualification-it was something he knew something about.

I remember that I went out to see Supreme Court Justice Jackson, who had been appointed to the prosecutorial position of American Chief of Counsel. ${ }^{146}$ I went out to where he lived, in McLean, Virginia,

143. For an account of Tom Clark's succession of Francis Biddle as Attorney General, see Biddle, supra note 92, at 364-66.

144. See Tusa \& Tusa, supra note 105, at 110-11 (regarding Biddle's appointment).

145. See Whitney R. Harris, Tyranny on Trial: The Evidence at Nuremberg 499 (1954) ("There was nothing improper in this. One who serves as a legislator may later be called to act in the capacity of prosecutor or judge.").

146. See Taylor, supra note 105 , at $39-40$; Tusa \& Tusa, supra note 105 , at $67-70$ (describing politics surrounding appointment). 
to get his view of the ethical aspect of it. I had drafted the executive order under which Jackson was appointed-at Judge Rosenman's request, because Rosenman wanted to keep it out of the Department of Justice mill until it was announced from the White House, since they had good reason to anticipate that there might be very real criticism of the Supreme Court Justice shifting to a prosecutor. I really went out to Virginia to see Jackson for Biddle, although I don't remember that he asked me to. Jackson had some qualms about it, but he was very fond of Biddle and they were close friends, and I don't think that he really interposed an objection. He thought we had to handle it with care.

The deal was sort of musical chairs, you know. I mean, a Justice becomes a prosecutor, a prosecutor becomes a Judge. An Assistant Attorney General becomes a law clerk.

In fact, it was controversial. Nuremberg was controversial. It was bound to be. But I can't see that our prior involvement really played any significant role, not even when Senator Taft took a hostile view of Nuremberg in his speeches after it was over-I don't think that our prior involvement was what he emphasized. ${ }^{147}$

Having made many of your own views well known, in memos about the question of aggression and criminal membership, did you anticipate having difficulty in writing a verdict, or feeling awkward about having to rule?

Don't forget, I wasn't asked to be a Judge. But I suspect, though I have no specific recollection of it, that I considered that it was a very attractive opportunity to achieve at a later stage what we had been unable to achieve earlier. And that indeed is, I think, exactly what happened.

One of the interesting initial assignments that I received once we had gotten settled at Nuremberg had to do with finding counsel for the defendants. The potential defendants, the persons alive who had been named in the indictment, ${ }^{148}$ were brought to Nuremberg by the military, whose prisoners they were, and housed in the detention facilities of the big courthouse in Nuremberg.

But they were simply individuals. Impotent, behind bars, without

147. In a speech in 1946 presented at Kenyon College, Senator Taft complained that the Tribunal had "helped to clothe vengeance in the forms of legal procedure, with the result that the whole idea of justice in Europe might [be] discredited." Walter W. Ruch, Taft Condemns Hanging for Nazis as Unjust Verdict, N.Y. Times, Oct. 6, 1946, at 1, 45; accord Russell Kirk \& James McClellan, The Political Principles of Robert A. Taft 100-04 (1967) (describing Taft's opposition to application of ex post facto laws in Nuremberg trials); War Crimes and the American Conscience 1-2 (Erwin Knoll \& Judith N. McFadden eds., 1970) (quoting Taft's speech expressing doubts of value of Nuremberg trials as precedent).

148. See generally Secretariat of the Tribunal at Nuremberg, Trial of the Major War Criminals Before the International Military Tribunal, Nuremberg, 14 Nov. 1945-1 Oct. 1946 (1947-1949) (proceedings); see also His Majesty's Stationery Office, London, The Trial of German Major War Criminals, Proceedings of the International Military Tribunal sitting at Nuremberg, Germany 3-46 (1946). 
help of any kind. We considered that our first problem was to be sure that they were represented by counsel, and this meant for us that so far as possible they should be represented by counsel of their choice. But we had very little knowledge of the German bar and even less of those of its members who had survived the war. Hence, our first problem was to undertake a census of the available German bar. This was done rapidly and efficiently by persons assigned to the Tribunal as assistants, and within a short time we were able to advise the prisoners of the list of surviving and available German lawyers willing to serve, from whom voluntary choices of counsel were rapidly made. And then those persons were brought to Nuremberg and billeted at government expense, so that the process of representation could get under way.

Was consideration given to retaining attorneys from other countries?

Well, we were dealing with German lawyers. There was no request for lawyers from other countries, as I recall. They would not have been excluded, I don't think, if they'd been requested and available and willing to serve. But all the defense lawyers, as I recollect them, were Germans, and many of them well-known people, like, for example, Professor Exner of Munich, ${ }^{149}$ one of the leading pre-war German criminologists, whose work was known to me as a criminal law teacher, and who had indeed even been a visitor during my time as a teacher and had been at Columbia as a guest. So one of our real successes was, I believe, uncovering a bevy of German lawyers to accord these defendants representation that really was of their choice.

Some of the representation was exceptionally able, for example that on behalf of Admiral Doenitz ${ }^{150}$ - the man designated by Hitler to succeed him-by a fairly young German naval officer by the name of Otto Kranzbuhler. ${ }^{151}$ But it was not all brilliant representation. We were full of stories based upon the lack of understanding of cross-examination, so common among Continental European lawyers. Such as the incident in which the lawyer representing Kaltenbrunner, ${ }^{152}$ one of

149. Professor Franz Exner (1881-1947): Exner served as counsel to General Alfred Jodl, Chief of the Operations Staff of the High Command of the German Armed Forces. Prior to the war he was the author of more than a dozen works on criminology. See, e.g., Franz Exner, Kriminologie (1949); see also Airey Neave, On Trial at Nuremberg 299 (1978) (discussing Exner's representation); Nation on Trial, supra note 127, at 175-77 (same).

150. Grand Admiral Karl Doenitz (1891-1980): Doenitz briefly succeeded Adolf Hitler as Chancellor of the Third Reich. He led the U-boat offensive against Allied shipping, and became Commander-in-Chief of the German Navy in 1943. Convicted at Nuremberg, Doenitz served ten years in prison until his release in 1956. See Louis L. Snyder, Hitler's Elite 18, 93 (1989).

151. Otto Kranzbuhler: Kranzbuhler was Grand Admiral Doenitz's defense lawyer at the trials. At the time, Kranzbuhler was a young naval attorney from the German Judge Advocate's office. See Otto Kranzbuhler, Nuremberg Eighteen Years Afterwards, 14 DePaul L. Rev. 333, 333 (1965).

152. Ernst Kaltenbrunner (1903-1946): One of the Nazi defendants, Kaltenbrunner served under Himmler and was directly involved in controlling the Gestapo and the 
the real Nazi thugs, was cross-examining a witness against Kaltenbrunner, who had testified to the execution of some young students in Munich.

And this lawyer said, "Mr. Witness, you testified to the execution of these students, but I did not hear you mention the name of the defendant Kaltenbrunner." To which Mr. Witness replied: "Oh, my Lord, did I forget to name him? Why, he was the ringleader of the whole thing."

Well, something of that sort occurred in some cases, although I don't think that it really affected the results in any way. On the whole, these lawyers were diligent and devoted, and I think really achieved wonders in their representation-demonstrating again what hardly needs demonstration, the importance of counsel for the defense.

Do you think that the German representation accentuated the image of this as a trial of the victors against the vanquished? Would it have been different, say, if Telford Taylor ${ }^{153}$ had been assigned to represent one of the German defendants?

I don't think that would have been agreeable to the defendants. I mean, it was very important to them that they have total confidence in their lawyers, and I think that whatever else any of them may have thought, I don't think that any of them thought that they were deprived in any way of the opportunity to tell their story. On the contrary, it was Justice Jackson who was continually protesting that the Tribunal was going too far afield in permitting the defendants to advance recriminations, $t u$ quoques [you also], against the prosecution.

I think that the Tribunal was very sensitive to the proposition, to the extent that we were charging the Germans with conduct that we asserted to be reprehensible, that we ourselves had engaged in, that the charges lost their moral and equitable foundation. And that was particularly true in the case of Doenitz and submarine warfare. It was matters of this sort, of course, that led to acquittals in the trial, which nobody had considered to be even a conceivable possibility at the time the pro-

concentration camp network. One Gestapo official testified that orders for executions by Security Police came from Heinrich Himmler through Kaltenbrunner and were passed on to concentration camp commanders. Analyzing Kaltenbrunner's prison writings, historian Peter Black found "[m]ost remarkable . . . the absence of any guilt, remorse, or even reflection on the millions of innocent people who had been murdered by the regime that he served." Peter R. Black, Erust Kaltenbrunner: Ideological Soldier of the Third Reich 271 (1984). Kaltenbrunner was sentenced to death by the tribunal. See id. at 134-271.

153. Telford Taylor (b. 1908): An attorney and law professor, Taylor served as Jackson's deputy at the International Tribunal, and later was Chief of Counsel for War Crimes at the twelve United States Military Tribunal trials at Nuremberg. See Taylor, supra note 105, at ix-xii. Regarding German perceptions of Nuremberg as "victor's justice," see generally Nation on Trial, supra note 127, at 85-92; Nuremberg: German Views of the War Trials (Wilbourn E. Benton \& Georg Grimm eds., 1955) (compiling articles by German law professors and lawyers analyzing the Nuremberg Trials). 
ceedings began. ${ }^{154}$ Again, I say without hesitation that nobody would have considered $a$ priori that was a possibility, that there would be acquittals. I think the defendants were as surprised as anybody; but the truth of the matter was that measuring the evidence by the relevant legal standards, the Tribunal really performed.

We understand that there were moments of friction in the Tribunal-for instance, disagreements regarding accusations that the Germans had perpetrated the slaughter of Poles in the Katyn Forest.

That was an interesting incident. The indictment accused the Germans of the slaughter. The Germans, on the other hand, contended that this had been committed by the Russians. ${ }^{155}$

And so when evidence was offered on that point, the Germans wished to come forward with evidence that the thing had been the work of the Russians. Of course, the Russian Judges had a conniption fit. There was great protest by the Russian prosecutor, General Rudenko, ${ }^{156}$ which was argued in court. And then the matter came to a conference for decision.

Biddle and I sat up most of the night, working on a memorandum opinion that he would file as a dissent if the judgment of the court sustained the Russian objection. When he read this opinion in the conference, the Russian objection collapsed. As against having that dissenting opinion read or having the evidence in, General Nikitchenko, ${ }^{157}$ the Russian Judge, the senior, very sensibly concluded that he'd rather have the evidence than the dissent. There were other episodes of this kind.

There also was very significant tension between Jackson and Biddle. One occasion for it was in connection with the unsuccessful examination of Goering, when Jackson attempted to cut Goering off from going back to pre-war German history, and the Tribunal, very properly, I thought, figured that would be totally self-defeating and wrong.

154. Three of the twenty-two original defendants, Hjalmar Schacht, Franz von Pappen, and Hans Fritsche, were acquitted. See Tusa \& Tusa, supra note 105, at 446-73. Admiral Doenitz recieved a prison term of 10 years based upon charges unrelated to the submarine warfare count, upon which he was not convicted. See Taylor, supra note 105 , at 592-93.

155. See, e.g., id. at 41-12 (describing Russian allegations and surrounding controversy). The matter was finally resolved with the Soviet government's admission, in April, 1990, that the Soviet NKVD police had carried out the massacre on personal instructions from Stalin. See Masha Hamilton, Gorbachev Documents Soviet Guilt at Katyn, L.A. Times, Apr. 14, 1990, at A1, A6.

156. Roman A. Rudenko (1907-1981): Rudenko served as the chief Soviet prosecutor at the Trials and later as a member of the Central Committee of the Communist Party of the Soviet Union. See The International Who's Who 1488 (42d ed. 1978-1979) (entry for "Rudenko, Roman Andregevich").

157. General I.T. Nikitchenko (d. 1967): Nikitchenko was the Soviet judge on the Tribunal. See Iola Nikitchenko, Soviet Judge Dies, N.Y. Times, Apr. 23, 1967, at 92. 
The other and more important aspect of it had to do with the charge against the organizations, which you asked me about earlier. Jackson never anticipated anything like these roving commissions to take testimony - and he opposed them bitterly as contrary to the intention of the Charter. ${ }^{158}$ Maybe it was contrary to Bernays' intention, and I guess the Russians supported him; but fortunately the French stayed with us, and the British and we were clear that our joint standards of procedural fairness were involved.

And on that point Jackson summoned me, as a friend, and a friend of both, to try to fill him in on what was eating Biddle. That gave me an opportunity to expatiate in camera a little bit on what seemed fair and didn't seem fair, a lecture as I think in my old age I'd be very hesitant to offer a Supreme Court Justice, but in my thirties it seemed to be alright. Jackson didn't like it, but he took it, and I think it may have contributed somewhat to at least mutual understanding in easing some of these tensions as we moved along.

\section{Where were you during most of the trials?}

One of the most interesting aspects of Nuremberg for me was that Biddle insisted that I sit with the Tribunal. And I did that, all the time that I was there. I would always sit directly behind the American Judges, and sometimes I had functions to perform for them. I never addressed the Tribunal in those sessions, but I would frequently hand Biddle a memorandum that had been prepared for him.

\section{What were your personal feelings toward the defendants?}

I didn't come to know them, except as one comes to know somebody by observation. They were not an appealing group, and it was, I guess, rather difficult to view them with objectivity. I had no great feelings either emotionally or intellectually about them, except to note, as everyone did, the spectacle of the fall from grandeur that they exhibited sitting there in the dock; but one can find the same spectacle in many Shakespearean plays. On the whole they seemed like a tearful groupas the enormity of what they had done was driven home even to themand it was, for example, through the exhibition of motion pictures of atrocities introduced as evidence. Even they were rendered almost speechless by what they saw and heard.

After all, humanity is humanity, and that was the most striking part of it, that the efforts at true defense were in a sense so limited. I mean,

158. Article Eight of the London Charter provided that the Tribunal might declare organizations as well as individuals criminal. Commissions were appointed to determine whether six indicted Nazi organizations should be so declared. See Tusa \& Tusa, supra note 105, at 424-43. Ultimately, the Trihunal ruled that four organizations-the Gestapo, the S.S. (Schutz Staffel), the Reich Cabinet, and the S.D. (Sicherheitsdienst)-were criminal organizations, and that the criminality of a defendant prosecuted for membership required proof that the accused joined voluntarily and knew that the organization was engaged in crime as defined by Article Six of the Charter. See Taylor, supra note 105 , at $555-59$. 
a defendant might be willing to have it developed that he was free of guilt with respect to a particular thing, but not that the thing was somehow defensible.

After the trial had been on for some months, it became pretty evident to all of us what the substance of the testimony would be. In order to be as useful as possible, those of us trying to help the Judges, particularly Adrian Fisher ${ }^{159}$ and I, would spend less time in court and more time working on blocking out memoranda that we hoped would be of use to the Judges in the court when the time for judgment came. I pretty much worked on the legal problems and Butch, as we called Adrian, worked very carefully and importantly and helpfully on summarizing the evidence. I have in my office a set of summaries of the evidence, with respect to each charge, that is really an amazing piece of work.

1 think it is fair to say that our work product was of rather considerable importance in the production of the court-both in reaching the verdict and in the writing of the judgment, which was divided up among the Judges, but the particularly close relationship between Birkett and Biddle helped a lot on that. And, of course, Judge Parker, the alternate Judge, too-he and I were very close.

In April of 1946, Biddle's wife and my then-wife came over to join us-the first two wives to travel to occupied Germany in the post-war period, I think. Biddle had made it a condition of his accepting the job that Mrs. Biddle would be permitted to join him. When she was ready to go, my wife agreed to accompany her. And the four of us moved into, we lived together in, an old castle, a baroque structure and residence that just demonstrated everything that was in bad taste in German culture, except that it had a marvelous collection of statuary.

Anyhow, we lived together there, the four of us, for about six weeks, when we reached the time where it was understood that I would leave. The testimony was just about completed and what remained was the verdict and the judgment.

It was time to return to Columbia for the summer session, and I still had an important case to argue in the District of Columbia, concerning the seizure of a company which had concealed German ownership.

Did you continue to work on the Nuremberg matter after you returned?

Biddle had insisted that if I were to leave, he should still feel free to consult me about the judgment, which, in fact, he did, and the draft opinion, which was drawn to some extent from memoranda of mine,

159. Adrian S. Fisher (1914-1983): A lawyer and captain in the U.S. Air Force, Fisher left a position as Assistant to the Assistant Secretary of War to become a technical advisor to the American judges at Nuremberg. After the war he held many important positions within the State Department and played a major role as a disarmament negotiator during the Kennedy and Johnson Administrations. See Adrian S. Fisher, 69, Arms Treaty Negotiator, N.Y. Times, Mar. 19, 1983, at 28. 
especially the material on conspiracy and complicity that I mentioned to you earlier. I was not entirely removed from Nuremberg until the thing was actually over.

What were relations like between the Americans and the other Judges of the Tribunal?

On the whole, the relationship with the French was cordial. It helped that Biddle spoke very fluent French and had been born in Paris and lived there. Biddle exercised a great deal of influence with them.

And there was very little tension between us and the British. Between the British simpatico business and the Birkett liaison. The Presiding Judge, Lord Justice Lawrence ${ }^{160}$-who later became Baron Oaksey-was a fellow who looked like a perfect English Judge. I mean, he had the right paunch, the right bald head, the right round face, the right rotund voice. He was perhaps an average, workaday, intermediate Appellate Court Judge.

But Biddle and I had deliberately decided that it was better for him [Biddle] not to be Chief Judge, in view of Jackson's dominant role. That if Biddle were the Chief Judge, then the whole thing would be nothing but an American venture. And so Biddle made the sacrifice of foregoing certain election as Chief Judge, if he had wanted it.

And on the whole I think Chief Judge Lawrence, precisely because of his combination of insensitivity and imperturbability, was maybe a plus for the undertaking. But Lawrence was a front. Birkett was the man who did the work. The American group learned to work with him and indeed became close friends with him. A real fun person. A great lawyer. Later went to the House of Lords. Lord Birkett.

What I wanted to say was that the British relationship on one hand, the French on the other, meant that the Tribunal, notwithstanding the Russians, was pretty much under control, and that was of great importance to the result. Of course, the Russians voted against all the acquittals. And on conviction you needed three votes. The prosecution needed three votes, so that if the British and we stood fast, there could be no conviction.

I think this is one reason why there was never any further use of the International Tribunal. Both the Russians and the French realized that once you had a four-man Tribunal, with the requirement of three votes to convict, they were simply pawns in the hands of the Americans and the British.

\section{That had not been foreseen?}

160. Sir Geoffrey Lawrence (d. 1971): Lawrence became a barrister in 1906 and served as an artillery officer in World War 1. As presiding judge at Nuremberg, Lawrence passed the death sentence on twelve Nazi officials (including Martin Bormann in absentia). In recognition of his service at Nuremberg, Lawrence was created a baron and titled Lord Oaksey, Lord Justice of Appeal. See Lord Oaksey, Presiding Judge at Nuremberg Trials, Is Dead, N.Y. Times, Aug. 30, 1971, at 32. 
Well, 1 won't say that it had not been foreseen by anybody. We were well aware of the potential power that it gave us. On the other hand, we were equally aware that it gave the Russians and the French, if they combined, an equal negative. It was stacked, as perhaps a criminal proceeding should be, in favor of the defense. It was a very important point as bearing on procedural fairness. 1t's like the requirement of proof beyond a reasonable doubt.

And what do you think about the Nuremberg experience in retrospect?

I will try to put it simply. I never had the sense that by prosecuting the Germans, whatever the grounds for prosecution, that we were in a position to make a very solid stab toward deterring future aggression or atrocities or anything else. I say as a criminal lawyer, that isn't my sense of the way the criminal law functions effectively, when one considers all the uncertainties that are involved in marshalling international action against any kind of official conduct. One can hardly expect that governmental officials are going to be guided by the fear of prosecution and conviction, or even execution. Just as capital punishment is an ineffective deterrent to ordinary domestic murder, its effectiveness is infinitely attenuated in dealing with this kind of situation.

What I did think and still think, however, is that the undertaking of so much of the world to condemn the Germans on the grounds established at Nuremberg tended, at least with persons of good will, to solidify respect for and belief in the norms that we propounded as the basis for critical judgment. I'm not saying that sensitive, well-intentioned people needed this, but that somehow or other in the conscience of people of the world this is a strengthening factor, just as the domestic condemnation of murder and rape and robbery is, in some unknowable and indeterminate measure, a strengthening factor in the reprobation and condemnation of that kind of domestic conduct.

This is all in the largely speculative realm of the remote consequences for the psyche of man internationally, on which none of us, I think, can have any very profound judgment. We can have faith, rather than judgment.

But one thing I am absolutely sure of, and this is for me the justification of the Nuremberg undertaking. It's ironical. I see the main justification not in providing deserved punishment, but in preventing undeserved punishment.

Let me begin by telling you of an episode. There came a time when I wasn't in Nuremberg-December or January, about the turn of the year 1945-1946. The President directed me to go to Prague, to make certain representations to President Benes, ${ }^{161}$ who had just come

161. Dr. Edvard Benes (1884-1948): Benes served as second President of the Czechoslovak Republic and, together with Thomas G. Mazaryk, was its major architect. After the war ended, Benes struggled to maintain the independence of Czechoslovakia despite Soviet efforts to harass noncommunists. In February 1948, Benes acquiesced in a communist coup and resigned the presidency. He died a few weeks after resigning, "a 
into office upon the liberation of Czechoslovakia. The Russians were instrumental in the liberation of Prague, and fearing that some important American industrial enterprises in the neighborhood of Prague might be nationalized, I was to make representation to Benes that there was no justification for nationalizing them.

So I arranged to drive from Nuremberg down there, along with Sidney Alderman, one of Jackson's chief assistants, a Washington lawyer who was General Counsel to the Southern Railroad at that time, a very good lawyer who had presented the Czech case in Nuremberg. ${ }^{162}$ I arranged to have him go with me, because, of course, the Czechs were grateful to him for presenting their grievances.

We got an Army car and we drove from Nuremberg to Prague in a snowstorm. Almost got killed a million times, because the roads were full of shell holes, and they hadn't really yet cleaned up the debris of the war. I remember that from Weisbaden, say, down to Prague there was a burned out tank about every hundred yards, and you could smell the stink of death if you opened the car window. There is an odor that is unmistakable and deplorable.

As we passed through villages or towns, we were flabbergasted to see that all people had armbands on-like the armbands the Jews had been required to wear. When we got to Prague we went immediately to the main hotel, where we were set up. We got there towards evening, and of course, we'd been driving for hours, so after parking our things, we went out for a walk.

As we walked on Wenceslas Square, we were flabbergasted to see men and women, usually in couples, in full evening dress, walking along rapidly. And when we followed them, they would disappear down a kiosk and be gone. So we followed them down the kiosk, and there we came on an immense dancing palace. A huge dance hall. About the size of an armory, with balconies all around and there must have been thousands of people. Not in black tie. White tie and tails. And women in evening dress. We identified ourselves at the gate as Americans, and we were immediately greeted with open arms, and ushered in.

So we stayed there a while, watching this dancing. There were about three orchestras at different places around. And then, finally, we went back to the hotel.

The next day, at ten o'clock in the Charles Palace, we had this date with Benes. Speaking English well, he greeted us very pleasantly. The first thing any of us said to him was, well, "we arrived in Prague last night and we immediately took a walk and were flabbergasted to see so

defeated man." Albion Ross, Benes Dies in Coma at 64; Czech Cabinet Meets Today, N.Y. Times, Sept. 4, 1948, at $1,7$.

162. Sidney S. Alderman (1892-195?): A 1916 graduate of Duke Law School, Alderman was chosen in 1945 as First Assistant to the Chief Counsel for War Crimes. See Taylor, supra note 105 , at $46-47$. 
many people in full evening dress attending that dance that was going on."

He said, "Yes-during the German occupation my people were forbidden by the Germans to dance." He said, "Ever since the liberation, they have been dancing." Very moving business.

I then said, "Well that was a lovely thing to see, but I must say we saw something on the way down, driving down, that was not so lovely. Everybody in the Sudetenland seems to have a colored arm band now. What does this mean?"

Well, he said, "The armbands signify whether they must go back to Germany or whether they may remain in the Sudetenland, or whether some other destiny awaits them."

I asked him, "Doesn't it trouble you that having fought against such stigmatization of human beings, that the first fruit of victory is to repeat it?"

And at this he got very stiff, and he said, "All during the war the Sudetenland wanted to be German. Now it will have its wish." We could never get anything else out of him. ${ }^{163}$

I refer to the armbands of the Sudeten Germans and to Benes' comment as evidence of what even the most gentle and civilized of Europeans, who had been on the short end of the German operation, felt when the war was over. I could have pointed more strikingly, I guess, to the fate of Mussolini and similar lynchings that occurred.

I say to you on the basis of such observations as I could make while I was in Germany and traveled to other spots of immediate post-war Europe that if the governments of the victorious powers had not declared an intention to render justice on bases at least similar to those that were articulated in the London Charter, the blood bath that would have occurred against anybody asserted to be connected in any way with the German leadership or activities would have been beyond belief. ${ }^{164}$

And so, I say ironically, as I began: paradoxically, the principal function of Nuremberg and supplementary trials was not to administer punishment, but to influence its withholding, its postponement, while passions cooled, and to give reason a chance to be operative in determining who deserved to be punished. If the Allied powers had simply washed their hands of this question, the liberation governments on the one hand, and the masses in Germany and Poland on the other, coupled with the liberated prisoners-what they would have done is almost as unthinkable as what the Nazis did.

163. Benes considered the "transfer" of Sudetenland Germans back to Germany "vital to Czechoslovokia's security." Edward Taborsky, President Edvard Benes: Between East and West 1938-1948, at 125 (1981).

164. According to historian Bradley Smith, the Tribunal "may have made a major contribution to justice simply by delaying many of the trials for twelve or fifteen months, thus allowing time for passions to cool." Reaching Judgment, supra note 101, at 303. 
This is not such an abstruse explanation. If we ask, you know, "when does the criminal law do more good than harm, even domestically," the best answer is not going to be terribly different.

The one position on Nuremberg for which 1 had absolutely no tolerance whatsoever was the argument against a trial and in favor of what had been the British position, that they should have been shot, but they shouldn't have been tried. You may call Nuremberg a wholly political affair, if you want to, but at least it represented a rational effort to decide how force would be applied and to apply it only where the criteria for its application were met. And for anybody to say that it was a poorer thing to do than to apply violence as punishment without any criteria, without any effort to see if criteria were met, it seemed to me on the face of it to be the one totally indefensible position.

Why do you think it is that the Nuremberg Tribunal seems to have happened only once in our history ${ }^{165}$ and hasn't been repeated in the aftermath of wars since World War II?

When do you suppose it might have been repeated? When what people were in the hands of what powers in a position to conduct trials and impose condemnation? Everything that has happened since World War 11 , that 1 can think of, ended in a stalemate, with nobody in a position to administer punishment to anybody.

And if subsequent to the Second World War there had been a situation where war ended in outright victory, would a Nuremberg procedure have been an effective means for punishment?

Suppose Vietnam, let us say, ended with a military victory. Would we have undertaken to try and punish the Vietnamese? Well I certainly think we would have, for atrocities. And after all, the Calley trial was some indication that these thoughts are not exactly dead. ${ }^{166}$

165. There was, of course, "the other Nuremberg," the Japanese war-crimes trial, in which 25 defendants were found guilty of crimes against international law and 7 were executed by hanging. See Arnold C. Brackman, The Other Nuremberg: The Untold Story of the Tokyo War Crimes Trials app. at 406-13 (1987). The idea of a war-crimes trial to punish aggressors has been suggested occasionally in the years since Nuremberg. The war in Indochina prompted calls for reconvening a war-crimes tribunal. See, e.g., Telford Taylor, Nuremberg and Vietnam: An American Tragedy 182 (1970). See generally Crimes of War (Ricbard A. Falk et al. eds., 197I) (exploring idea of war crimes tribunal); Donald A. Wells, War Crimes and Laws of War 81-116 (1984) (exploring difficulties of identifying and prosecuting war crimes).

During the 1991 war against Iraq, the Bush administration considered a war crimes prosecution of Saddam Hussein and other military leaders of lraq for mistreatment of prisoners and other violations of international standards of wartime behavior. See Paul Dedard, Bush Talks of Atrocity Trial for Saddam, Wash. Times, Oct. 16, 1990, at Al. More recently United Nations and United States officials have called for a war crimes tribunal in connection with alleged Bosnian atrocities. See Elaine Sciolino, U.S. Names Figures It Wants Charged with War Crimes, N.Y. Times, Dec. 17, 1992, at 1.

166. Lieutenant William Calley was accused and convicted or ordering U.S. soldiers to massacre innocent civilians in the village of My Lai during the Vietnam War. See Seymour Hersh, Cover-Up: The Army's Secret Investigation of the Massacre at My 
Yet I guess that in our own conduct in Vietnam, we often failed to observe the norms that we avow and respect. So that one would have to say that based on that or even the Korean War experience, which I suppose are the two episodes you could point to for us, the ideals of the Nuremberg effort were often disregarded. But these are not the only ideals that have been disregarded in the last thirty years. We have witnessed after all a lamentable decline in any approach to operable standards, with the polarization of the United Nations and the frustration of all the hopes that animated its foundation. No, nobody could say either that Nuremberg or the ideals that seemed briefly to animate international conduct in the wake of the Second World War has fared well in the thirty-five or so years since.

What if the North Vietnamese had won, and captured General Westmoreland, and placed him on trial for violation of the principle of waging aggressive war? ${ }^{167}$

If I had thought that they did have a case against Westmoreland, I think I would not have regarded it as abusive. After all, the United States of America, after Nuremberg, took the lead in urging the United Nations to reaffirm the principles of the Nuremberg Judgment. Congress has never done anything to disavow that action. Quite the contrary, I was surprised recently reading Professor Henkin's Restatement of the Foreign Relations Law of the United States, Revised, to see to what an extent Congressional action in the intervening period, in one way or another, by incorporation, by reference, or reaffirmation, has accorded vitality to the idea of crimes against humanity, for example. ${ }^{168}$

I have to add one other thing, which I think you'd agree to. Once you establish a basis for criminal prosecution and punishment, you necessarily encounter a qualifying principle. That principle perceives abuse in the discriminatory invocation of those sanctions. It's inherent in the idea of justice and fairness that if we really mean to criminalize conduct that at least we make an effort to go at it on some reasonable, equitable across-the-board basis.

One of the reasons why I do not attach great significance, for the future, to the idea of international criminality, as distinguished from other international sanctions, is that the process of getting into motion the invocation and application of criminal sanctions is so ponderous, so slow, requires such painful building of consensus that it's very difficult to think of this as being the kind of thing that would be done on an equitable basis.

So I don't see a great future in the idea of an international criminal

Lai 4 (1972); Lt. Gen. William R. Peers, The My Lai lnquiry 18-19, 253 (1979) (discussing Calley's accusation and conviction).

167. William Childs Westmoreland (b. 1914): Westmoreland commanded U.S. forces in Vietnam from June, 1968 to July, 1972. See generally William C. Westmoreland, A Soldier Reports (1976) (describing experiences in Vietnam).

168. See Restatement (Third) of the Foreign Relations Law of the United States $\S 404$ \& reporters' note (1986) (Louis Henkin, Chief Reporter). 
court. In the post-Nuremberg period, I was constantly requested to join in efforts to establish an international criminal court, this, that, or the other thing. I've studiously abstained from joining in such efforts, and the reason is, as I said, that, my perception of Nuremberg is really more negative than positive in the sense that I stated. Fortunately, the need for that kind of negative intervention to prevent private or unofficial violence really is nothing that has been presented to us in a significant way.

Hannah Arendt, in her book Eichmann in Jerusalem, suggested that in some sense the Nuremberg Tribunal allowed the Germans and others an emotional catharsis, and in some ways it absolved more people than it should have of guilt for the Holocaust and for the war itself. ${ }^{169}$

On the other hand, the Germans have been pretty good on the prosecutions. They've even extended the statute of limitations. Eichmann, despite the fact that he was kidnapped by the Israelis from Argentina, got no German support against the illegal trial in Israel. After all, what basis did Israel have to assert jurisdiction over Eichmann, even after they kidnapped him? The world was far more tolerant, I should say, of a relatively indefensible assertion of jurisdiction on the part of Israel ${ }^{170}$ than it would be as to similarly indefensible assertions of jurisdictions in situations where provocation had been less extreme.

You wrote a paper shortly after the Nuremberg trials in which you countered most criticisms of Nuremberg. ${ }^{171}$ But you found some morit in the criticism that the criminal sanctions were applied only to the enemy and not the victors. You said that this fact argued that "Nuremberg was the assumption of an irrevocable obligation to build a world of just laws that shall apply to all, with institutions strong enough to carry it into effect. If we fail, we shall hear from the German ruins an attack on the Nuremberg judgment as the second 'dictat of Versailles, ' and notwithstanding the goodness of our intentions, we may have no sufficient answer." Our question is, have we failed to build that world of just laws, and if so, do we have a sufficient answer to the criticism you discussed?

Nuremberg has been a kind of relief to the German conscience, rather than the reverse. German criticism of Nuremberg has been muted. How do you explain that? One point, I gness, is that to a degree that nobody would have anticipated when I wrote that, the victorious powers joined in the rehabilitation of the German nation-at least the West German nation-much faster, much more effectively than anybody would have foreseen as possible. That is part of what we were doing in building a world of justice, of just laws. It is a little different

169. See Hannah Arendt, Eichmann in Jerusalem: A Report on the Banality of Evil 13 (1963).

170. See Herbert Wechsler, Adolph Eichmann and the Law: Was His Trial by an Israeli Court Justified? 'No' . . , I9 N.Y. County Law. Ass'n B. Bull. 100, 101-02 (1962).

171. See Herbert Wechsler, The Issues of the Nuremberg Trial, 62 Pol. Sci. $Q 11$, 18-25 (1947), reprinted in Herbert Wechsler, Principles, Politics and Fundamental Law 138-57 (1961). 
vision than the one that 1 guess was in my mind when 1 wrote the lines you quote, but more, rather than less, important, I think.

We've made some progress building the world of just laws, I think, and that's part of what I was saying earlier. We've learned, since I wrote that piece, how difficult the undertaking is and how slow the progress has to be.

\section{MODELS FOR LAW}

As the 1950s closed and the 1960s started, the legal community extended two platforms to Professor Wechsler that allowed him prominently to state his views and forcefully to direct many activities of the profession. In 1958, he was asked to deliver the Oliver Wendell Holmes lecture at Harvard; this became the basis for his article, Toward Neutral Principles of Constitutional Law. ${ }^{172}$ In 1962 the American Law Institute invited him to become its director.

These invitations recognized past contributions in constitutional law and criminal law as much as they anticipated his work product-contributions that had taken shape with Wechsler's return to academic life after his departure from Nuremberg. Within just a few years, his collaboration with Henry Hart produced the casebook Hart and Wechsler's The Federal Courts and the Federal System, acclaimed as "definitive" a short time after it was published in 1953. ${ }^{173}$ Wechsler also had renewed his interest in domestic criminal law, and during the 1950s began to develop the Model Penal Code of the American Law Institute, a powerful intellectual framework for rationalizing, and to an extent unifying, American criminal law.

In 1950 or so, I was approached by several officers of the American Law Institute to talk about what the Institute might usefully do in the field of criminal law. The Institute had almost gotten going in the early 1930 s on a project that the Depression put a stop to, and this was a revival of interest on their part. 1 told them that the best opportunity for the Institute to be useful was to devote itself to the effort to develop a model code of criminal law, like the model code of criminal procedure that the lnstitute had developed in the early 1930s, which had been very widely copied by state legislatures throughout the country. ${ }^{174}$

Judge Goodrich, Director of the Institute, ${ }^{175}$ indicated that he had been having conversations with the Rockefeller Foundation about the

172. For discussion of the article's influence, see supra note 9; infra notes $190-206$ and accompanying text.

173. In a recent review of the third edition, Professor Akhil Amar described the first edition as "probably the most important and influential casebook ever written." Akhil R. Amar, Law Story, 102 Harv. L. Rev. 688, 688 (1989).

174. See Model Code of Criminal Procedure (Official Draft 1930).

175. Herbert F. Goodrich (1889-1962): An eminent conflict of laws scholar, and former Dean of the University of Pennsylvania Law School, Judge Herbert F. Goodrich of the United States Court of Appeals for the Third Circuit was the second Director, following the Institute's first Director and founding father, William Draper Lewis. See Paul A. Wolkin, ALI-ABA ... XL! 8 (1988). 
possibilities of obtaining assistance for Institute efforts in the criminal law area. He took me down to talk to an official at the Foundation, and out of this developed the proposals for the Foundation to give the Institute a small grant to devote a year to exploring the possibilities of mutual work in the criminal law field. And after that 1 was retained to take the lead in establishing and working with an advisory committee to see if a consensus could be developed about a useful project.

1 took that on, and 1 drafted the memoranda, which are reproduced essentially in my Harvard Law Review article called The Challenge of a Model Penal Code. ${ }^{176}$ The advisory committee had several meetings on the basis of my memoranda, and they ended with the almost unanimous endorsement of the proposals outlined there-that the lnstitute undertake the development of a model code. On the basis of that endorsement, the Foundation made a much larger grant to the lnstitute. I was retained as chief reporter, and two others collaborated with me. ${ }^{177}$

From 1952 until the Code was completed-that is to say, for ten years - the development of the Model Penal Code absorbed every bit of time and energy that 1 had. This was my introduction to the Institute. And I did not stop working on it until the final publication. ${ }^{178}$

The point is that we really held off because it became evident very early in the game that the black letter of the code was being a very influential document indeed. So much so that, in the next twenty years, there were substantive revisions and recodifications of the penal code in this country in something like thirty-six or thirty-seven jurisdictions, with the Model Penal Code functioning as a primary source for these works. ${ }^{179}$

The other thing that's happened is that a great deal of the Model Penal Code has entered into the teaching materials for criminal law. There isn't any longer, I guess, any major teaching book that doesn't present a pretty full picture of what the Model Code solutions to particular problems are, and something of the background and the antecedent law, and indeed something of the interpretation that has been accorded to the new law.

176. Herbert Wechsler, The Challenge of a Model Penal Code, 65 Harv. L. Rev. 1097 (1952).

177. Louis B. Schwartz and Paul W. Tappan served as Associate Reporters. See id. at 1097 n.2.

178. The Revised Code and commentaries were finally published in seven volumes in 1985. See Model Penal Code and Commentaries (Official Draft and Revised Comments 1985).

179. See id. at xi (foreword by Herbert Wechsler). Wechsler asserts that the revision or recodification efforts in at least 34 jurisdictions were "influenced in some part by the positions taken in the Model [Penal] Code, though the extent to which particular formulations or approaches of the Model were adopted or adapted varied extensively from state to state." 1d. See also Herbert Wechsler, Codification of the Criminal Law in the United States: The Model Penal Code, 68 Colum. L. Rev. 1425, 1427-28 (1968). 

states?

What accounted for the phenomenal success of the Model Code among the

One thing is that it came at a very propitious time. Our penal codes, such as they were, were old, disorganized, fragmentary, uneven. 1 think there had been for years a large disposition to do something about this, but nobody really was in a position to do very much without having something to work with. The thing that the model provided was a compendious, but workable, point at which to begin; something to compare what a jurisdiction had with a standard that had some general support. That's one thing.

The second thing is that the Law Enforcement Assistance Administration 180 was able and willing to provide funds for state projects of this kind. Not that great sums of money were involved, but even modest sums are not easy to obtain in the ordinary state legislative setting.

Thirdly, we came up with what seemed like fair and workable solutions, rather than a document that would have seemed to the average legislator to be way off beat. This was helpful in obtaining the attention for and utilization of the Model Code as a source. I don't mean to suggest for a moment that everybody approved everything that we did, because that was not the case and we didn't expect it to be the case.

The conception of the "model" was helpful. We never overpressed the position. We didn't propose it as a uniform law, for example, with its potential demand that you not deviate therefrom. We proposed it modestly as a source, and I think that its success is some indication of the rhetorical effectiveness of understatement in this world, as against overstatement.

Why did the Model Penal Code fail to be adopted by the federal government?

You may remember that the Brown Commission came up with a proposed draft for a federal criminal code that was developed under the direction of Louis Schwartz, and naturally drew very heavily on the Model Code. ${ }^{181}$ I testified at the first hearings on the Brown

180. The Law Enforcement Assistance Administration was an agency within the Department of Justice charged with encouraging improvements in state law enforcement and empowered to make monetary grants to state governments, public agencies, institutions of higher education, or private research organizations. lt was created by Title I of the Omnibus Crime Control and Safe Streets Act of 1968, Pub. L. No. 90-351, 82 Stat. 197 (1968).

181. In 1966 Congress created a bipartisan National Commission on Reform of Federal Criminal Laws, former California Governor Edmund G. Brown serving as its chairman. The Brown Commission issued its final report in 1971. In the years that followed, alternative versions of reform were introduced by Senators McClellan of Arkansas and Hruska of Nebraska, two of the more conservative members of the Brown Commission, and by the Department of Justice. Louis B. Schwartz, at that time a Professor at the University of Pennsylvania Law School, served as Director of the Commission. For Schwartz's involvement with the MPC, see supra note 177 and accompanying text; see also Louis B. Schwartz, Reform of the Federal Criminal Law: 
Commission report. ${ }^{182}$ I thought there was a significant likelihood that much of it would be successful in Congress. There was no particular show of opposition.

As the matter dragged on through the years, however, with more and more difficulties interposed and more and more concessions to those difficulties, the bill lost a great deal of its character. On the other hand, it did organize the subject in a way in which it had never been organized in the federal law, and its enactment would provide the foundation on which some of the things that were omitted-for example, defenses were omitted for the most part-and would in the end be added to the Code. So I don't regard the federal battle as entirely lost. I guess the simplest answer to your question, however, is that there are more contrary views to be dealt with and reconciled on a national basis than there are likely to be in a given state legislature.

To make a long story about my appointment to the Directorship of the Institute short, the official draft of the Model Penal Code was approved in 1962. Not very long after that, in May of 1962, Judge Goodrich, the Director of the Institute, suddenly died. Sometime in that Fall, Norris Darrell ${ }^{183}$ approached me, and much to my surprise invited me to take over as Director. This was just at the time when I was writing the New York Times brief. ${ }^{184}$ I accepted with the understanding that I would complete my work for the Times before taking over.

What goals did you set for yourself as Director, and what goals did you set for the Iristitute?

I don't think I can say that I consciously set any set of goals for the Institute, other than to carry on and possibly expand somewhat the type of work that had been done. I was particularly interested myself, as the Model Penal Code work indicated, in the legislative development of the law, as distingnished from the mere Restatement work that was a very important aspect of the Institute's operations from the very beginning.

But the Institute had been moving in the direction that I favored anyhow. They had done the Uniform Commercial Code: ${ }^{185}$ the unification, after all, of the commercial law of the country-an enormous

Issues, Tactics, and Prospects, 41 L. \& Contemp. Probs. 1, 2-3 (Winter 1977) (describing the policy behind and development of Brown Commission's proposal).

182. For Wechsler's testimony, see 2 Reform of the Federal Criminal Laws: Hearings Before the Subcomm. on Criminal Laws and Procedures of the Senate Comm. on the Judiciary, 92d Cong., 1st Sess. 520-59 (1971).

183. Norris Darrell, Jr. (1899-1989): An expert in tax law, Darrell served as a partner of the New York law firm Sullivan \& Cromwell for 42 years and as President of the American Law Institute for 15 years. In the latter capacity he headed a project that served as a model for the Internal Revenue Code of 1954. See Norris Darrell, Lawyer and Tax Expert, 90, N.Y. Times, Aug. 15, 1989, at B5.

184. See supra note 11 and accompanying text.

185. Uniform Commercial Code (Official Draft, Texts and Comments Edition 1952). 
achievement. That had been completed. They'd done the Model Penal Code.

When I took over as Director, Judge Goodrich and the President ${ }^{186}$ had just succeeded in attaining foundation support for three legislative projects. First, the work in land use regulation that became the Model Land Development Code. Secondly, the work in criminal procedure that became the Model Code of Pre-Arraignment Procedure. Thirdly, the work in federal taxation that became the Federal Estate and Gift Tax Project. And the Institute was already at work at that time on the Federal Jurisdiction project that had been suggested by Chief Justice Warren-a study of the division of jurisdiction between federal and state courts. ${ }^{187}$

So my intention of carrying on and expanding legislative work as a major aspect of Institute work was really not a new thing, but perhaps the more self-conscious pursuit of that goal than had been articulated theretofore.

I also had a very strong sense that it was necessary to carry forward the conception of the Restatement work that had come in with the Restatement (Second)-a relaxation of the rigorous notion in the old Restatements that we were undertaking to restate only the law as it is. The law as it is is never that sharply differentiated from the law as it should be or as it will be, particularly when you're dealing with case law, because of the elbow room that American courts have to reshape the decisional norms under which the common law develops.

I guess I made this more articulate than anybody had been willing to make it in the old regime, and not without provoking denunciation. You'll find an article in the American Bar Association Joumal by Fred Helms stating that denunciation, and my response to it. ${ }^{188}$ But this relaxation of the old attitude that the ALI's task was only to restate existing law is congenial to the Institute as it exists today. And instead of diminishing the influence of our work, I think it's perfectly clear that it has enormously enhanced it.

In my years as Director, we not only completed the four projects we to some extent inherited, but we financed and undertook and completed the Federal Securities Code. Then we undertook to redo the Restatement of the Foreign Relations Law of the United States. We undertook

186. Norris Darrell was serving as President of the American Law Institute in 1962. See Model Penal Code at iii (Proposed Official Draft 1962).

187. Model Code of Pre-Arraignment Procedure (Tentative Draft No. 5 1972); Model Land Dev. Code (1975) (Complete Text and Reporter's Commentary); American Law Institute, Federal Estate and Gift Taxation: Recommendations of the American Law Institute and Reporters' Studies (1968); American Law Institute, Study of the Division of Jurisdiction Between State and Federal Courts (1969).

188. Actually, Helms responded to Wechsler. See Herbert Wechsler, The Course of the Restatements, 55 A.B.A. J. 147 (1969); Fred B. Helms, The Restatements: Existing Law or Prophecy, 56 A.B.A. J. I52 (1970). 
an enormous program in the federal tax field: a study of the federal tax law governing corporate acquisitions and distributions was completed. We undertook a re-examination of I.R.S. provisions governing the taxation of partners and partnerships, and the income of estates and trusts. We inaugurated a very much needed study of the international aspects of the federal income tax. In more traditional areas of the Institute's work, we inaugurated and completed the second Restatement of the Law of Judgments, an enormously important aspect of lawyer's law. We completed the second Restatement of the Law of Contracts.

This is a fairly sizeable work product, when you get down to it. Added to that, and perhaps more important than most of it, is the fact that we have financed a new study, a new piece of work, addressed to the structure and governance of corporations, which is to be a restatement with recommendations. The first utterly frank effort to combine Restatement functions with legislative and similar recommendations. It's too early to say very much about it, but the next few years will tell the tale as to whether this type of approach is viable. Whatever its fate might be, it's quite clear that it will not be a quiet one. ${ }^{189}$

How far can the Institute go in helping to get its recommendations adopted by various political institutions?

We are very, very strict about that. We don't do anything. We take the view that when the Institute has spoken, the Institute's role is finished, and it's then up to interested individuals or organizations who care about the matter to do something about it. I will not even ask to testify in support of a bill, either in Congress or in a state legislature, that is based on Institute work, but I will testify by invitation of a Committee, but not in my capacity as Director. And nothing prevents, for example, Louis Loss, the reporter for the Securities Code, from playing the role that he as the author of the principal treatise in the securities field would naturally play on any legislation of this kind.

Could you talk about the process of reaching consensus within the Institute?

I'd be glad to, because the success of the Institute rests in considerable part on the wisdom of its procedure. When we develop a project, the way we go about it is to select a reporter or reporters, whose business it is to do the work and develop the product with advice, and we have different ways of setting up the advisers. The by-laws of the Institute say that nothing can be published as the work of the Institute unless it has been approved by a vote of the Council, which is the governing body-about sixty people-and also by a vote of the membership at an annual meeting. So that we have adopted the Calhoun principle calling for concurrent majorities. And before work goes to

189. In 1984 Wechsler resigned from the institute and was replaced by Professor Geoffrey Hazard of the Yale Law School. Wechsler's prophesy about the Institute's corporate governance project proved accurate. It did not receive final approval until 1992, after a decade of intense controversy. See John C. Coffee, Jr., The ALl Corporate Governance Project, N.Y. L.J., June 9, 1992, at 1. 
the Council, it will be subjected to very close scrutiny by a group of advisers.

In any event, a reporter has to be a creative type who has a sense for what he's doing and where he wants to go. He's got to get reasonable peer support from these advisory groups before he takes it to the Council, which is again an eclectic group composed of practitioners, judges, and professors, and a very critical, but able, group. And then he's got to, in the end, gain support of the much larger body that will attend an annual meeting and where chance and accident might play a large part as to who's there.

As Director, I would sit with all these advisory groups and that became the way I spent my life, just hopping from meeting to meeting. I would try to get the President, the reporter, or somebody else to preside, usually. I provided a thread of continuity, along with the reporter. I really thought of myself as the nexus between the reporters and the Council.

On the whole, I respected the relative autonomy of the reporters. I didn't try to direct them in the narrow sense of the term, but if I thought they lost faith in what they were doing, I would put a stop to it. Or change the reporter, because reporters were designated by the Council on my nomination as Director, as indeed advisers were. So I had a good deal of indirect control on who did what, though I tried to exercise that control as Judge Goodrich did, by encouraging sound advice from the reporters, on whose effectiveness in the end the whole thing depends. On the whole, I didn't like to be cast in a position where I had to disapprove of anything they did. I had lost reporters by death and resignation, but there was only one whom I would have replaced had I not had the good fortune to have the President of the United States appoint him to a sub-Cabinet position, and thus save me from the painful necessity of removing him.

Does code-making by committees stifle legal innovation?

Don't forget, we're dealing with people who have no constituencies. It may be true that in the political process, the more cooks you introduce in the broth the flatter the broth is going to be, but we're usually dealing with academics as reporters. We're dealing with people, mature people, who know exactly what they're doing, or are experts in the fields in which they're working. I don't think anybody would say as to its products that the Institute has not been innovative. Indeed, if there has been any charge against us in recent years, it is that we've been excessively innovative.

\section{The Neutral Principles Concept}

We'd like to turn to the Neutral Principles article, which has become a classic of constitutional law scholarship. How did that piece develop?

As a teacher of constitutional law, as well as an ex-law clerk, one of my central interests throughout has been the work and contribution of 
the Supreme Court and its place in the scheme of things in the government of the United States. I suppose you could say that my views on constitutional law generally date me very definitely as somebody who began to deal with these problems in the era of the Taft Court, or the early Hughes Court-the era when the decisions seemed to be a road block to legislative developments that I and many others thought to be necessary for the decent humanization of American capitalism.

And so we spent the first years of our lives preaching against the judicial veto of legislation of a type that we considered to be desirable.

When the constitutional revolution came, as we indicated when we were talking about Roosevelt's court-packing plan at an earlier meeting, ${ }^{190}$ the problems for all of us became: How can we defend a judicial veto in areas where we thought it helpful in American life-civil liberties area, personal freedom, First Amendment-and at the same time condemn it in the areas where we considered it unhelpful? And an awful lot of the seminal thinking of my generation went into the confrontation of that antithesis, producing such things as the Carolene Products footnote ${ }^{191}$ and other efforts to develop a theoretical support for a civil-liberties-protective court and an active legislative function in the area of the economy. We may have grossly oversimplified the matter by drawing that antithesis as we did, but anyhow we did tend to draw it that way. Having learned through that experience of the consequences of judicial excess, we became highly sensitive to it, and on the whole, I should say, eager to develop the type of critique that would contribute to avoiding it.

Now somebody who started off his thinking on these matters as an enthusiast for judicial activism is likely to think differently about such problems. If you look at a book like Laurence Tribe's treatise, ${ }^{192}$ you'll see what I mean. Here's somebody who wasn't born when the problems that I'm talking about arose, and came to this field at a much later time, and whose approach to activism is accordingly more tolerant.

But that's to put the matter very generally. I became worried and concerned in this area precisely at the point where it seemed to me that an understandable judicial desire to produce specific results, principally in the area of race, had begun to produce decisions that I could not relate to a defensible rationale of interpretation or development. ${ }^{193}$ In

190. See supra text accompanying notes $45-47$.

191. See supra note 49 and accompanying text.

192. See Laurence H. Tribe, American Constitutional Law (1978). The second edition of Tribe's treatise was published in 1988.

193. For a particularly vehement critique of Wechsler's treatment of the race issue, see Horwitz, supra note 6, at 267 ("From the perspective of a generation later, Wechsler's difficulties in holding racially discriminatory statutes unconstitutional have that inaccessible quality of ancient structures of understanding derived from a time when a fundamentally different moral order seemed to prevail with assurance."). 
teaching constitutional law, I found myself inevitably driven to a critical approach to decisions like the restrictive covenant decisions, Shelly $v$. Kraemer, ${ }^{194}$ and the white primary decisions. ${ }^{195}$ And I guess this was climaxed by the school segregation question. ${ }^{196}$

I hadn't been teaching constitutional law at Columbia, but in 1956 I went up to Harvard as a Visiting Professor. The invitation to teach constitutional law at Harvard led into a more extensive commitment pedagogically than I had had up to then. I'd been teaching federal courts, not constitutional law.

That year at Harvard, working in constitutional law, was a challenging experience that set my mind along the lines that the neutral principles paper later developed. I found myself developing the neutral principles idea as a pedagogical instrument for pushing students into subjecting their own immediate reactions of approval or disapproval of the results of a particular decision to a more searching type of criterion of evaluation. And I found this effective as a pedagogical instrument, pushing students into a degree of rethinking-exactly what a pedagogical effort ought to achieve.

The neutral principles idea has meant so many different things to so many different people, and has been vigorously attacked by people who had no understanding of what it was all about. It is not, of course, thought of as a formula to guide or produce the decision of hard cases, but rather as a negative test, a test to be applied by a judge, with the essence of the question whether he is being adequately consistent in the process of adjudication, in reaching a particular type of result in a particular type of case. That is to say, essentially that he ask himself, "Would I reach the same result if the substantive interests were otherwise?"

It is a fault of the lecture that it seems that I am claiming more for the neutral principles concept than I ever undertook to claim for it. But remember, I was attacking three lines of decisions, all of which had developed in the Supreme Court-at least two of which had developed before Warren (Shelley and the white primary case), and only one of which had come during the Warren era in the Brown decision. There was nothing novel in my insistence that the legitimacy of the decision is to be gauged in terms of the reasons given for it. After all, that had been said as long ago as Chief Justice Taney, speaking for the Supreme Court itself. That lay at the root of the Court's willingness to reconsider decisions, particularly constitutional decisions, on the showing that the grounds on which they had been placed were erroneous.

194. 334 U.S. 1 (1948) (Fourteenth Amendment prohibits state enforcement of private housing agreements that discriminate on basis of race); accord Barrows $v$. Jackson, 346 U.S. 249 (1953) (same).

195. See, e.g., Smith v. Allwright, 321 U.S. 649 (1944) (exclusion of blacks from Democratic Party primary constitutes state action violating Fifteenth Amendment).

196. See Brown v. Board of Educ., 347 U.S. 483 (1954). 
In any event, I did enough talking along this line in my teaching at Harvard and also in chewing the rag with colleagues on the faculty, so that after I came back to Columbia, when there came a time when they were good enough to ask me to fill a vacancy in the annual Holmes Lectureship, it was perfectly clear that what they wanted me to do was to put up or shut up on this line that I had been following pedagogically and disputatiously, going back to 1956-1957. I thought it was a good thing that I should accept the challenge to try to put it on paper, which I had not done at all. So I agreed to do it and went to work.

There isn't anything in the paper that I regret or would do differently now. As 1 said in the Preface to my book, when it was published as a book, maybe "neutral" isn't the best word to convey the thought I was attempting to convey, but I still don't know of any better word. "Objective," "disinterested"- - these have been suggested. They are, to be sure, less combative. ${ }^{197}$

The results in the three lines of cases you criticized in that article are probably results that you would agree with?

Exactly. That's why I picked them.

What was the point of picking those, rather than, say, cases that you disagreed with, which also might have been used as examples for your point?

It seemed more powerful, more persuasive, and morally preferable to exhibit the tension between results and bases, in terms of situations where I liked the result, but felt a moral obligation to question the grounds than to take the easy cases where I disliked the result and undertook to question the grounds. ${ }^{198}$ Indeed, one of the elements of rhetorical effectiveness in the piece was precisely that 1 persuaded people that I liked the results and still felt it important to question the grounds.

Were you surprised by the vehemence of protest from individuals who liked the results in the cases and didn't like your criticism of them?

I think the only one that really surprised me was Eugene

197. See Herbert Wechsler, Principles, Politics, and Fundamental Law: Selected Essays (1961).

198. In 1969, a decade after expressing his view of the Brown case in the Holmes lecture, published as Toward Neutral Principles of Constitutional Law, 73 Harv. L. Rev. 1 (1959), Wechsler considered a principle for the decision that would have been more acceptable to him than the one adopted by the Court. Wechsler stated:

I have spoken elsewhere of my difficulties with the School opinion. The decision is, however, more acceptable when its principle is seen to be that any racial line, implying an invidious assessment, may no longer be prescribed by law or by official action. That principle, it should be noted, means that race may still be made a factor in decision if the ground is not invidious in implication, as in striving for a racial balance to correct inequalities of opportunity that may be found. ...

Herbert Wechsler, The Nationalization of Civil Liberties and Civil Rights, 12 Tex. Q. 10, 23 (1969) (citations omitted). 
Rostow, ${ }^{199}$ because I had the sense that he knew better and ought to have known better. Some people who wrote about it were people whose intellect I had no respect for anyhow. Others who took me to task seemed to me to be merely using me to effect a line of preachment that they wished to put across and were not really serious about having read what I wrote. I thought that was true of Charles Clark, for example, just as I would think that it would be true now of Skelly Wright. ${ }^{200}$

Were there criticisms that you thought had a legitimate basis?

No. No, I didn't think so, because most of the criticism I thought was on grounds that I had fully taken account of. Such as, for example, the proposition that adjudication and constitutional interpretation is necessarily a value-laden enterprise. Well, I had not only taken account of that, I had said that. My point was that a judge is obliged, insofar as he deals with the extrapolation and extension of a particular constitutionally protected value, to give it an even-handed development. That's hardly a profound thesis. But on the other hand, a legislator may not necessarily be so obliged to do, unless he's under some constitutional compulsion, such as the Equal Protection Clause. It is inherent in the legislative process to be selective, but it is not inherent in the judicial process.

That's a concept that certainly leaves room for a much broader exegesis, and that is indeed the difficulty with the piece, which, after all,

199. Eugene Victor Rostow (b. 1913): Rostow earned A.B. (1933), LL.B. (1937), and A.M. (1944) degrees from Yale University and completed post-graduate work at King's College, Cambridge University (M.A. 1934). After practicing law in New York, he joined the Yale Law School faculty in 1938, where he eventually served as Dean (1955-1965). See 2 Who's Who in America 2893 (47th ed. 1992). Rostow criticized Wechsler's Neutral Principles article in Eugene V. Rostow, The Sovereign Prerogative: The Supreme Court and the Quest for Law 24-39 (1962).

200. Charles Edward Clark (1889-1963): A graduate of Yale (B.A. 1911) and Yale Law School (LL.B. 1913), Clark joined the Connecticut bar in 1913 and practiced in New Haven until 1919. He returned to Yale Law School where he served successively as assistant professor, associate professor, professor and Lines Professor (1919-1929); Sterling Professor and Dean of Yale Law School (1929-1939). He was appointed to the United States Court of Appeals for the Second Circuit, first as Judge (1939), and then as Chief Judge (1954-1959). 4 Who Was Who in America 174 (1968). For his discussion of Wechsler's Neutral Principles article, see Charles E. Clark, A Plea for the Unprincipled Decision, 49 Va. L. Rev. 660, 661, 663-64 (1963).

James Skelly Wright (1911-1988): After receiving his Ph.D. from Loyola University in 1931, Wright taught high school and went to law school, earning the LL.B. from Loyola in 1934. He then lectured in English history at Loyola (1936-1937), served as an Assistant U.S. Attorney in New Orleans (1937-1942 and 1945-1946), and as the U.S. Attorney for the Eastern District of Louisiana (1948-1949) before he finally joined the federal bench in 1949. He was a member of the faculty of Loyola Law School from 1950-1962. He served for thirteen years as a U.S. District Judge before he went to the United States Court of Appeals for the District of Columbia Circuit, first as Judge (1962-1982) and then as Chief Judge (1982-1987). 9 Who Was Who in America 388 (1989). Wright implicitly criticized Wechsler's Neutral Principles article, without mentioning it directly, in J. Skelly Wright, Color-Blind Theories and Color-Conscious Remedies, 47 U. Chi. L. Rev. 213, 214 (1979). 
was only a lecture. I think that H.L.A. Hart was right, when somebody asked him to comment on the lecture and he said, "Why, in order to do so I'd have to write a book." That's the one criticism of the lecture that I would be prepared to make myself, that it was perhaps wrong to venture this as a thesis in a piece of this dimension, rather than to write it as a book.

How come you've never written a book that would fill out the neutral principles article?

As I think your tapes will indicate, I've been too busy doing other things.

How does the neutral principles concept compare to the common-law method of distinguishing and following previous cases, and what kinds of constraints would the application of neutral principles place on a common-law judge?

The principal constraint that it would place on a common-law judge is that he develop for his own guidance and evenhandedness of judgment a considered position as to how he will read cases and what degree of bondage he will feel towards precedent as new cases arise. What grounds of distinction he will consider to be adequate to differentiate and release from bondage to precedent. And that, I guess, from my point of view is about it. And when you think about great commonlaw judges and their writing, what do you find but precisely this type of effort to articulate standards of judgment. What is Cardozo's Nature of the Judicial Process, or his Columbia Lectures, Paradoxes of Legal Science, except precisely that?201 Pioneering efforts to do precisely that. Take, for example, Judge Roger Traynor ${ }^{202}$ of California, ex-Chief Judge Traynor, and his many articles on standards of adjudication. ${ }^{203}$ Precisely that same effort to develop and articulate evenhanded guides for himself and for others.

Nobody can do this perfectly. Some judges who are evenhanded by instinct may not really be quite able and sufficiently competent at articulation to put in words a statement of what it is that they are doing. I think Judge Hand somewhere said, in one of his early papers, speaking of the judicial function, something like, "Nobody does this perfectly. Nobody quite knows exactly how it should be done. Great judges do it better than the rest of us." And all of this is true. What is

201. See supra note 15 and accompanying text.

202. Roger J. Traynor (1900-1983): A leading legal scholar who served for 30 years on the California Supreme Court as Justice (1940) and Chief Justice (1964), Traynor was innovative and controversial, often anticipating later rnlings by the U.S. Supreme Court. Following his retirement from the bench, Traynor taught at Hastings College of Law and participated in efforts to reform ethics codes for judges and lawyers. See Les Ledbetter, Roger J. Traynor, California Justice, N.Y. Times, May 17, 1983, at B6.

203. See generally Roger J. Traynor, The Traynor Reader: Nous Verrons: A Collection of Essays (1987) (memorial collection of Judge Traynor's lectures and articles). 
underlying is that the measure of greatness is really the adequacy with which this perception is grasped and guides adjudication.

Does Congress have to abide by neutral principles, in your view? Does the President? And if they're different, what is special about a court?

That it functions through law. It is not in the accepted understanding of its mission authorized by the body politic to create law, but only to apply it.

So in your view it would not be inappropriate for the President to take an action, and provide an explanation for it which he would not be willing to apply to other possible actions within the ambit of that explanation?

It would not be a distortion of his function, because he's an elected official and he may properly give special weight to the wishes and desires of the particular constituency that he considers elected him.

I think it's a terrible mistake and regrettable and bad for the country that Ronald Reagan seems to think that the way to improve the economy is to take benefits out of the hides of the poor and grant larger privileges to the wealthy. But I can't say that I consider it in any sense illegitimate for him to do that. I mean, it was perfectly plain that that was where he stood in the course of his campaign for election, and the people who voted for him have only themselves to blame for making so asinine a political choice. From my own point of view, I'll say that indeed 1 hope that the President would feel the same obligation that a court should feel, to provide a reasoned explanation of his official action. But I insist that he's not obliged by the nature of his function to do so. But I don't see any room for any similar view of the decision rendered by a court.

Is the neutral principles concept merely a description of how judges should decide cases, or is it something more, a condition of the legitimacy of judicial decisions?

The way I put it in the lecture was that 1 think we ask this of courts and that we wouldn't be willing that they exercise the special type of power that they do exercise, if there were not a convention that they should and would act only in this way.

Now whether you want to translate that into legitimacy raises the question of what you mean by legitimacy, and this is a very hard issue to deal with. I content myself with saying that from my point of view it is a misuse of judicial power to render decisions that are not compatible with the idea of neutral principles.

Many people associated this lecture with a call for an objective approach to a science of the law. What do you believe is the possibility of objectivity as a general matter?

Objectivity is more or less possible for individuals and courts and agencies and people and professors and lawyers. I think a degree of objectivity is obtainable. I think none of us can ever in the end get away from the fact that we are who we are and that it is we who are judging or writing or professing or whatever it may be. In other words, you 
might try to persuade me that, as some people believe, objectivity in adjudication, let's say, is a myth. One of the articles that attacked my piece is, I think, called The Myth of Neutrality in Constitutional Adjudication..$^{204}$ The authors undertook to remind us that judges are people too, and felt that they had made a contribution to human understanding, by this insight. The simple answer to all of this is that we should strive to be objective and we should be as objective as we can be. It is not true that objectivity is impossible, and it is not true, unfortunately, that it is ever perfectly attained.

Was the neutral principles article in some ways the crystallization of your Nuremberg experience?

I wouldn't put it that way. On the other hand, what I wrote about Nuremberg-particularly my emphasis on the importance, in that undertaking, that we judge the enemy only by standards that we would apply to ourselves, be willing to apply to ourselves, and feel obliged to apply to ourselves-does represent an articulation of my belief in neutral principles back then. My whole effort in the Nuremberg thing, in which I think I was on the whole quite successful in strengthening the natural instinct of Judge Biddle to perform in this way, was to persuade him that in reaching judgment at Nuremberg, only standards that we felt confident we would be ready to apply to ourselves should prevail. Over and over again in my memoranda, this point would be made.

Would you agree that your article represented the inevitable reaction, long overdue, to the more extreme aspects of Legal Realism, by emphasizing the importance of reason to the judicial process?

The only quarrel I have with that, really, is the implication that all realists are simple empiricists who disavow the role of reason. I think there were some of those people, who considered themselves to be protagonists of the Realist movement-whose thrust was wholly empirical and descriptive, and who seemed to have perceived no room for the normative in law and legal studies and legal action. But I don't think that is true of people like the Myth of Neutrality characters that I mentioned. I don't think their difficulty is that they're realists.

Did the younger generation of legal scholars follow on your work in the way that you might have expected or would expect?

I don't have any sense that I have disciples hanging around, and I don't have the sense that the younger generation is spending much time in reading what $I$ have written. That's not to speak in dispraise of the younger generation. I mean, I wasn't founding a school of thought.

I do think that on one point I perhaps would claim a modest influence here and on the direction of legal scholarship, by example more than by preachment. Legal scholarship is certainly much more legislative-minded than it was, say, when I began. I think I've played some Adjudication, 27 U. Chi. L. Rev. 661, 661-64, 693-95 (1960). 
part in interesting the legal profession in the legislative approach to law, and as much through the American Law Institute as in my own work.

1 say again about neutral principles that 1 never quite had the missionary sense about that article that so many people have kind of assumed I had. I didn't have a sense that the ideas that I was expressing had the novelty that some people think I thought they had. Remember that the occasion that provoked the piece was the set of lectures that Judge Learned Hand had given at Harvard the year before, ${ }^{205}$ really putting forth a view of the scope of judicial review that was acceptable to nobody, and that I thought it was important to reply to. That aspect of the paper is often overlooked. It was a defense of judicial review, not an attack on it. At the same time, I thought that if I was going to defend it, I ought also to indicate that I recognized that there was room for and need for critical consideration of standards. ${ }^{206}$

Could you talk a bit about how your life in the law has affected the other parts of your life?

It's kept me busy. No, I don't really know what to say about that. And I don't know what my life would have been like if I'd been something other than a lawyer or a law teacher.

If your father had not prevailed on you not to become a professor of French, for example, things might have been different.

He saved me from disaster. I would have been a colossal flop as a French teacher, that's perfectly clear. I guess the probability is that I would have starved to death. Maybe that's the answer.

205. See Learned Hand, The Bill of Rights (1958).

206. See Herbert Wechsler, The Courts and the Constitution, 65 Colum. L. Rev. 1001, 1013-14 (1965) ("The principle of neutral principles does not purport to yield a formula that makes it easy to decide hard cases or dispenses with the agony of judgment in arriving at decisions-as Mr. MacDougal seemed to imply that it did when he was here. Nor does it, as Dean Rostow has averred, repudiate 'all we have learned about law since Holmes published his Common Law in 1881.' Nor does it exclude value judgments from interpretation, as some others have alleged." (footnotes omitted)). 